\title{
The Pacific Northwest Residential \\ Consumer: Perceptions and Preferences of Home Heating Fuels, Major Appliances, and Appliance Fuels
}

\author{
S. A. Harkreader \\ M. P. Hattrup \\ R. O. Weijo, Project Manager
}

September 1988

Prepared for

the Bonneville Power Administration

Office of Conservation

under a Related Services Agreement

with the U.S. Department of Energy

Contract DE-AC06-76RLO 1830

Pacific Northwest Laboratory

Operated for the U.S. Department of Energy

by Battelle Memorial Institute 


\title{
DISCLAIMER
}

This report was prepared as an account of work sponsored by an agency of the United States Government. Neither the United States Government nor any agency thereof, nor Battelle Memorial Institute, nor any or their employees, makes any warranty, expressed or implied, or assumes any legal liability or responsibility for the accuracy, completeness, or usefulness of any information, apparatus, product, or process disclosed, or represents that its use would not infringe privately owned rights. Reference herein to any specific commercial product, process, or service by trade name, trademark, manufacturer, or othenwise does not necessarily constitute or imply its endorsement, recommendation, or favoring by the United States Government or any agency thereof, or Battelle Memorial Institute. The views and opinions of authors expressed herein do not necessarily state or reflect those of the United States Government or any agency thereof.

\author{
PACIFIC NORTHWEST LABORATORY \\ operated by \\ BATTELLE MEMORIAL INSTITUTE \\ for the \\ UNITED STATES DEPARTMENT OF ENERGY \\ under Contract DE-AC06-76RLO 1830
}

\begin{tabular}{|c|c|}
\hline \multicolumn{2}{|c|}{ Printed in the United States of America } \\
\hline \multicolumn{2}{|c|}{ Available from } \\
\hline \multicolumn{2}{|c|}{ National Technical Information Service } \\
\hline \multicolumn{2}{|c|}{ United States Department of Commerce } \\
\hline \multicolumn{2}{|c|}{5285 Port Royal Road } \\
\hline \multicolumn{2}{|c|}{ Springfield, Virginia 2216 T } \\
\hline \multicolumn{2}{|c|}{ NTIS Price Codes } \\
\hline \multicolumn{2}{|c|}{ Microfiche A01 } \\
\hline \multicolumn{2}{|c|}{ Printed Copy } \\
\hline & Price \\
\hline Pages & Codes \\
\hline $001-025$ & A02 \\
\hline $026-050$ & A03 \\
\hline $051-075$ & $\mathrm{~A} 04$ \\
\hline $076-100$ & A0S \\
\hline $101-125$ & $A 06$ \\
\hline$\uparrow 26-150$ & A07 \\
\hline $151-175$ & ADB \\
\hline 176.200 & $A 0 P$ \\
\hline $201-225$ & A10 \\
\hline $226-250$ & A11 \\
\hline $251-275$ & A12 \\
\hline $27 b-300$ & A13 \\
\hline
\end{tabular}


THE PACIFIC NORTHWEST RESIDENTIAL CONSUMER: PERCEPTIONS AND PREFERENCES OF HOME HEATING FUELS, MAJOR APPLIANCES, AND APPLIANCE FUELS

S. A. Harkreader

M. P. Hattrup

R. 0. Weijo, Project Manager

September 1988

Prepared for the Bonneville Power Administration office of Conservation under a Related Services Agreement with the U.S. Department of Energy Contract DE-ACO6-76RLO 1830

Pacific Northwest Laboratory Richland, Washington 99352 


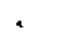

. 


\section{EXECUTIVE SUMMARY}

In 1983 the Bonneville Power Administration contracted with the Pacific Northwest Laboratory (PNL) to conduct an analysis of the marketing environment for Bonneville's conservation activities. Since this baseline residential study, PNL has conducted two follow up market research projects: Phase II in 1985, and Phase III, in 1988.

In this report we examine the respondents' perceptions, preferences, and fuel switching possibilities of fuels for home heating and major appliances. To aid in effective target marketing, the report identifies market segments according to consumers' demographics, life-cycle, attitudes, and opinions.

\section{PERCEPTIONS AND PREFERENCES FOR HOME HEATING FUELS}

Household perceptions of four major heating fuels and eight attributes of heating fuels are examined in the report. Household respondents rated safety as the most important attribute for a heating fuel to have. Safety was followed by dependability, economy, and efficiency. Households perceived all eight of the attributes to be very important for a heating fuel to possess. However, wood and fuel oil users rated the nonpolluting attribute lower than electricity and natural gas users.

of the four heating fuels examined, household respondents perceived electricity in the most positive light across all eight attributes, closely followed by natural gas. Distinguishing attributes of electricity are safety, cleanliness, and convenience. Natural gas is perceived to be more inexpensive and efficient. Fuel oil's greatest liability is perceived to be its cost. Wood's greatest liabilities are convenience and safety.

The respondents' perceptions of several of the attributes of electricity, natural gas, wood, and fuel oil were found to vary across heating fuel types, geographic region, smart shopper attitudes, and household iffe-cycle segments.

The findings on consumer perceptions of heating fuels and heating fuel attributes are useful in directing utility marketing programs. The attitudes of selected market segments can be modified with promotion strategies to 
shift their perceptions about a fuel. For example, if the switching of electricity to natural gas is of concern, marketing programs emphasizing the most positive aspects of electricity and the most negative aspects of natural gas can be directed to those consumer segments most likely to switch fuels.

\section{FUEL SWITCHING POTENTIAL FOR HOME HEATING FUELS}

The two most preferred heating fuels are electricity and natural gas. A comparison of respondents' present heating fuel and their preferred heating fuel reveals more of a potential for switching from electricity to natural gas. However, in any given year very little fuel switching actually occurs. The long replacement life of heating furnaces creates a situation where only three to four percent of households replace their furnace in any given year. of this percent, not all homeowners switch their heating fuel. Of the homeowners interviewed, only three percent switched primary heating fuels for reasons other than a change of residence.

Though little switching of primary heating fuels has occurred, in the long run, a small percentage of homes switching away from electricity each year will lead to electricity losing a large proportion of its market share. Where heating fuel switching is a concern, it is important to carefully study the reasons for customer preference for natural gas and develop a marketing program to begin neutralizing the long term loss of electricity's market share through fuel switching.

Influencing the fuel type of new residences will have the most effect on a fuel's market share in the long run. Since little fuel switching occurs, encouraging the use of electricity in new residences will ensure electricity's long term market share. Comparing the heating fuel type of homes with the year they were constructed indicates a trend towards the increased installation of natural gas as a primary heating fue 7 . Whereas wood heat experienced a growth in new residence installation during the seventies and the early eighties, it is presently being installed in fewer new homes. 


\section{THE PRIMARY HEAT HOOD USER}

In Western Washington, Western Oregon, and Eastern Washington/Northern Idaho/Western Montana, the proportion of wood users is around $17 \%$. Only $7 \%$ of the respondents in Eastern Oregon/Southern Idaho use wood for home heating.

Wood users perceive wood to be more economical, more dependable, safer, more comfortable, more efficient, more convenient, and more pleasing to the sense of smell than do users of other fuels. Hood users' primary reason for using the fuel is its low cost.

The potential of consumers switching to wood from electricity is smaller than the potential for switching to natural gas. Approximately $10 \%$ of those households using electricity prefer wood as a primary heating fuel. Twentythree percent of wood users reported preferring electricity as a primary heating fuel. If the switching of electricity to wood is a concern, the reasons for wood use and the perceptions of the attributes of wood suggest developing a program that emphasized al1 the costs of using wood, including the non-monetary costs.

\section{APPLIANCE FUEL CHOICE}

Electricity is the most used and preferred fuel for cooking, water heating, and clothes drying. Very little switching of appliance fuels occurs without a change of residence. Seventy-eight percent of those homeowners that have switched cooking fuels, changed from natural gas to electricity. Sixty-one percent of those homeowners that have switched water heating fuels, also changed from natural gas to electricity.

\section{HEAT PUMPS}

Only $4 \%$ of the homeowners reported having a heat pump. Forty-three percent of the homeowners reported being familiar with the heat pump system. Innovative homeowners and homeowners using electricity as a heating fuel were found to be more familiar with heat pump systems.

The two most often mentioned advantages and disadvantages of the heat pump were the same. A heat pump's efficient and reliable operation is the 
most mentioned advantage and its inefficiency and lack of reliability is the second most mentioned disadvantage. The economical operation of the heat pump is the second most mentioned advantage and its expensive operation is the most mentioned disadvantage.

The low familiarity with heat pumps and the misperceptions about them suggest that a communication program be developed to address two issues: 1) increasing the heat pump awareness of homeowners, and 2) correcting the inaccurate perceptions consumers have about heat pumps.

\section{THE WATER HEATER MARKET AND WATER HEATER MARKETING PROGRAMS}

Four percent of the homeowners reported presentiy being in the market for a water heater. However, 26\% of homeowners' water heaters are over 12 years old. Awareness of present water heater marketing programs is low among homeowners. However, respondents do feel utilities should be involved in programs promoting energy conservation investments and the most preferred incentives for purchasing a water heater are discounted prices and cash rebates. The low awareness of water heater marketing programs and the long replacement 1 ife of water heaters suggest that utilities might consider focusing their resources on marketing programs for retailers and not the final consumer. 


\section{CONTENTS}

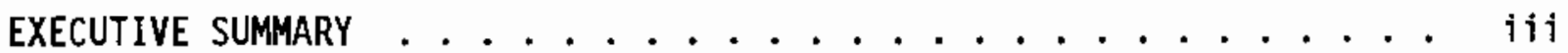

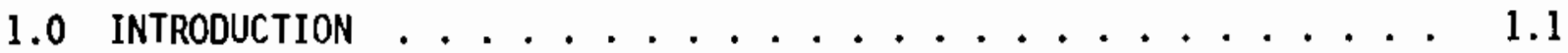

1.1 PHASE III - SURVEY AND SAMPLE DESCRIPTION $\ldots \ldots \ldots$

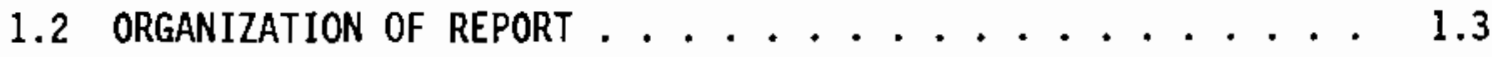

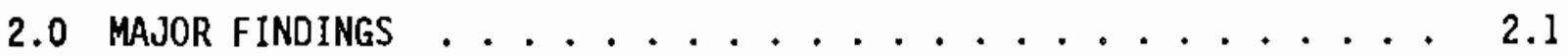

2.1 PERCEPTION OF HEATING FUELS .................. 2.1

2.2 FUEL SWITCHING OF HOME HEATING FUELS . . . . . . 2.2

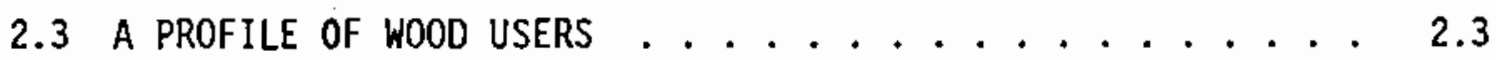

2.4 MAJOR APPLIANCE FUELS . . . . . . . . . . . . 2.4

2.5 HEAT PUMPS . . . . . . . . . . . . . . . 2.5

2.6 THE WATER HEATER MARKET AND AWARENESS OF WATER HEATER
MARKETING PROGRAMS . . . . . 2.5

3.0 DESCRIPTION OF SURVEYED HOUSEHOLDS. . . . . . . . . 3.1

4.0 PERCEPTIONS OF hEATING FUeLS AND THEIR ATtRIBUteS . . . . . . . . 4.1

4.1 PERCEIVED IMPORTANCE OF HEATING FUEL ATTRIBUTES $\ldots \ldots . . .4 .1$

4.2 CDNSUMER PERCEPTIONS OF HEATING FUELS $\ldots \ldots \ldots . \ldots . . \ldots$

4.2.1 Consumer Ratings of Fuel Attributes . . . . . . 4 4.3

4.2.2 Differences in Fuel Perceptions Across Segments . . 4.4

4.2.3 Consumers' Responses to Other Survey Questions . . 4.7

4.3 AN OVERVIEW OF THE PERCEPTION OF FUELS AND THEIR

ATTRIBUTES . . . . . . . . . . . . 4.9

5.0 FUEL SWITCHING AMONG HEATING FUELS $\ldots \ldots \ldots . \ldots . \ldots . \ldots$

5.1 PREFERENCES FOR HEATING FUELS AND DIFFERENCES ACROSS

SEGMENTS .......................... 5.1

5.2 PRESENT VERSUS PREFERRED HEATING FUEL . . . . . . . 5.3

5.3 PAST AND POTENTIAL FUEL SWITCHING ............... 5.3 


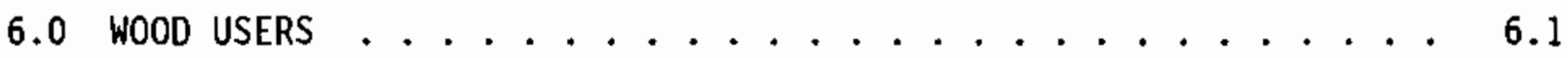

6.1 DESCRIPTION OF WOOD USER HOUSEHOLDS ............... 6.1

6.2 WOOD USERS' PERCEPTIONS OF HEATING FUELS . . . . . . 6.2

6.3 REASONS FOR WOOD USE AS A PRIMARY HEATING FUEL . . . . . 6.3

6.4 AMOUNT OF WOOD USED FOR HEATING ................ 6.4

7.0 APPLIANCE FUEL CHOICE . . . . . . . . . . . . 7.1

7.1 PRESENT AND PREFERRED APPLIANCE FUELS . . . . . . . 7.1

7.2 APPLIANCE FUEL SWITCHING . . . . . . . . . . . . 7.2

8.0 OWNERSHIP, FAMILIARITY, PERCEPTIONS, AND PURCHASE INTENT OF

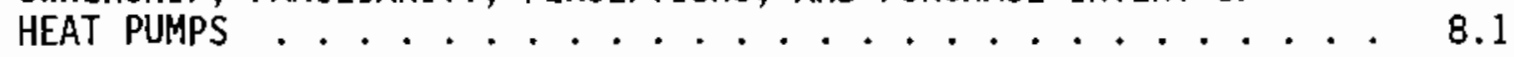

8.1 HEAT PUMP OWNERS . . . . . . . . . . . 8.1

8.2 HOMEOWNER'S LEVEL OF FAMILIARITY WITH HEAT PUMPS . . . . 8.2

8.3 HOMEOWNERS' PERCEPTIONS OF HEAT PUMPS ......... 8.3

8.4 HOMEOWNERS' INTENT TO PURCHASE A HEAT PUMP SYSTEM $\ldots \ldots . .8 .5$

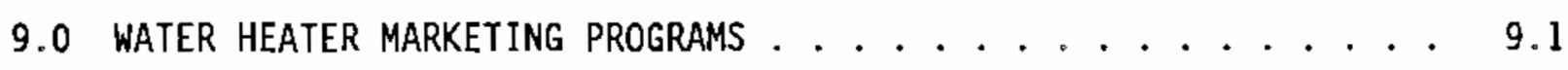

9.1 THE REPLACEMENT MARKET FOR RESIDENTIAL WATER HEATERS . . . . 9.1

9.2 WATER HEATER MARKETING PROGRAMS AND INCENTIVES . . . . . 9.2

10.0 REFERENCES ........................... 10.1

APPENDIX A - ANALYTICAL TECHNIQUES ............. A.1

APPENDIX B - SELECTED DEMOGRAPHICS . . . . . . . . . B.1

APPENDIX $c$ - PHASE III QUESTIONNAIRE . ............ c.1 


\section{FIGURES}

3.1 Primary Heating Fuel Distribution by Region . . . . . . . . 3.1

3.2 Geographic Distribution of Surveyed Households . . . . . . 3.2

4.1 Perceived Expense by Fuel Type . . . . . . . . . . . . 4.8

5.1 Percentage of Respondents in a Region Preferring a Specific

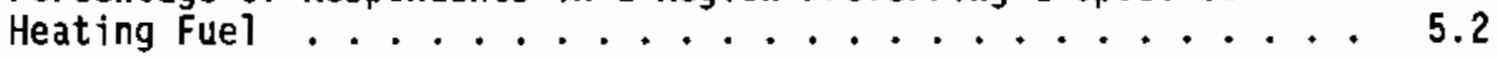

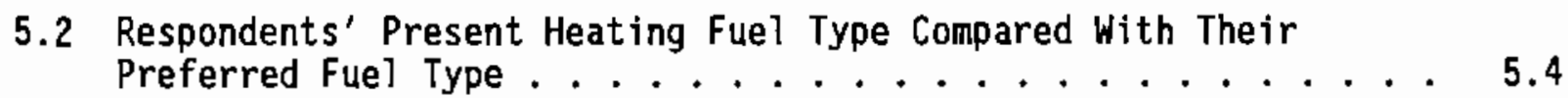

5.3 Respondents' Present Heating Fuel Type Compared With the Vintage of Their Home ................. 5.5

8.1 Intention to Purchase a Heat Pump by Region . . . . . . . . 8.6

8.2 Intention to Purchase a Heat Pump by Fuel Type . . . . . . 8.6

\section{TABLES}

4.1 Respondents' Ratings of Fuel Attributes . . . . . . . . . . 4.1

4.2 The Importance of a Nonpolluting Heating Fuel, Ratings by Primary Fuel Type .................... 4.2

4.3 Comparison of Means of the Positive Perception Scale, by Fuel Attribute .................. . . 4.3

4.4 Differences in the Perception of Fuel Attributes, by Heating Fuel Type............... 4.5

4.5 Mean Scores for Attributes that are Perceived Differently Between Smart Shoppers and Noncomparative Shoppers . . . . . . 4.6

4.6 Mean Scores for Attributes that are Perceived Differently Between Regions ............ . . . . . . . 4.6

4.7 Mean Scores for Attributes that are Perceived Differently, by Life-Cycle Segments . . . . . . . . . . . 4.7

5.1 Respondents' Mean Innovator Score, by Preferred Heating Fue1

6.1 Wood Users by Life-Cycle Segment . . . . . . . . . . . 6.2

6.2 Mean Rating of Fuel Attributes for Wood Users and Nonusers . . 6.3 
7.1 Homeowners' Reasons for Preferring a Cooking Fuel, by Preferred Cooking Fue] . . . . . . . . . 7.2

7.2 Homeowners' Primary Heating Fuel by Appliance Fuels . . . . . . 7.3

7.3 Present Cooking Fuel Compared with Preferred Cooking Fuel . . 7.3

7.4 Present Water Heating Fuel Compared with Preferred Water Heating Fuel ................ 7.3

7.5 Present Clothes Dryer Fuel Compared with Preferred Clothes Dryer Fuel ................ . . 7.4

7.6 Homeowner Switching of Cooking and Water Heating Fuels . . . . 7.4

8.1 Heat Pump Owners by Segmentation Schemes .......... 8.1

8.2 Familiarity with Heat Pumps, by Segmentation Schemes .....8 8.3

8.3 What Homeowners Like About Heat Pumps . . . . . . . . . 8.3

8.4 What Homeowners Dislike About Heat Pumps ......... . 8.4

9.1 Age of Water Heater by Region, Present Water Heating Fuel, and Preferred Water Heating Fue 1 . . . . . . . . . . 9.1

9.2 Respondents' Level of Agreement with Statements Concerning the Role of Utilities ................ 9.3 


\subsection{INTRODUCTION}

To develop the necessary information base for conservation planning, program design, and marketing, the Bonneville Power Administration contracted in 1983 with the Pacific Northwest Laboratory (PNL) to analyze the marketing environment for Bonneville's conservation activities. Under the project, a baseline residential conservation marketing study was completed. In addition, market segment studies were conducted for heat pump and solar water heaters and energy-efficient new homes.

The goal of studying the market environment is to aid in designing and implementing cost-effective conservation programs, including marketing. Understanding consumers' motivations, perceptions, and attitudes towards energy efficiency and programs promoting energy efficiency is a key to promoting participation in such programs. Effective marketing also involves identifying definitive market segments. Once identified, information is then targeted to the specific segments through appropriate access channels. Target marketing makes more efficient use of program dollars.

The 1983 baseline study involved telephone interviews with a stratified random sample of 2000 households in Bonneville's service territory. The study assessed household attitudes toward energy conservation, perceptions of institutions, conservation actions taken and investments made, and household media habits. The results were published in RMH Research, Inc. (1984) and compared with results from other studies (Fang 1985).

In 1985, PNL followed up this baseline study with Phase II of the Analysis of the Marketing Environment for Bonneville's Conservation Activities. For Phase II, 1058 telephone surveys were completed. A stratified random sample of the Bonneville's service territory was drawn. The objectives of Phase II were, "to track changes in consumer attitudes, interests, and opinion between 1983 and 1985; to identify more refined segments of the residential conservation market in terms of attitudes, interests, and opinions; and to test hypotheses concerning consumer conservation actions and investment 
behaviors" (Ivey et a]. 1987, p. 1.2). The study produced a series of reports on tracking, segmentation, fuel switching, and financing of energy investments.

\section{I.1 PHASE III - SURVEY AND SAMPLE DESCRIPTION}

This report is concerned with Phase III of the Analysis of the Marketing Environment for Bonneville's Conservation Activities. Phase III differs from Phase I and Phase II in that it emphasized fuel choice, perceptions of heating fuels, fuel preferences, and fuel switching. Phase IIl also differs in its study design. It consists of two surveys: a tracking survey and a fuels survey.

The tracking survey addresses most of the issues covered in Phase II. The tracking data were collected via a stratified random sample of Bonneville's service territory. The results of the tracking survey are discussed in Schultz and Bajley (1988).

The sample for the study, which is the subject of this report, is representative of the Bonneville's electric utility customer districts only, not the entire Pacific Northwest.

The sampling frame for the study consists of a clustered random sample of approximately 1000 residential households. Fifty random samples of enough telephone numbers to ensure 20 completed interviews were selected via a random digit dialing process from within all the zip codes in Bonneville's electric utility customer districts. The probability of any one sample being selected was based on the 1980 household populations within each zip code. The more populated the zip code area, the greater the likelihood that a sample would be drawn from it. This sampling methodology was chosen over a simple random sample to reduce the expense of collecting local data to compare with the survey data in future research efforts.

The sample was chosen to be representative of Bonneville's electric utility customer districts. By nature, telephone survey data are biased towards the views of those people more likely to complete telephone interviews. A $50 \%$ to $60 \%$ response rate is common for telephone marketing surveys. Variability in response rates is generally dependent on the efforts 
made with follow-up contacts, and the relevance of the survey to the people being interviewed (Kalton 1987). For this study, a three call-back procedure was employed. The initial refusal rate was $44 \%$. The termination rate was $10 \%$.

The low response rate was probably partially due to the length and the detailed nature of the survey questions. Also, the subject of the survey is not an interesting topic to most households. It is difficult to accurately assess what groups of people are not represented by the data because there is no data for them. Although the response rate is low, the data do represent a large proportion of Bonneville's service territory.

\subsection{ORGANIZATION OF REPORT}

To facilitate the readability and usefulness of this report, it covers the most interesting and relevant findings. It is not an inclusive discussion of the statistics used or a presentation of every possible finding. Its focus is identifying differences among segments of the population which are usefut in understanding household fuel consumption.

The major findings of the study are found in Chapter 2.0. In Chapter 3.0, the respondents are described in terms of segments. Five segmentation schemes appear throughout the report: geographic region; present heating fuel; 1ife-cycle; and two attitude segmentation schemes, "innovators" and "smart shoppers." Chapter 4.0 examines consumer perceptions of electricity, gas, and wood. It discusses eight characteristics of home heating fuels, the importance of each of the attributes to consumers, and the attributes consumers associate with each fuel. Chapter 5.0 addresses the fuel switching issue. The respondents' present heating fuel type is compared with their preferred heating fuel type and the potential for fuel switching is discussed in light of past fuel switching behavior. Chapter 6.0 examines wood users more closely. Their perceptions of wood and their reasons for using wood are discussed. Other wood issues included are the amount of wood burned, the cost of wood use, and the decline of wood use.

Present fuels, preferred fuels, and fuel switching among appliances is reported in Chapter 7.0. Chapter 8.0 is concerned with the heat pump market. 
Likes and dislikes, likelihood of purchasing a heat pump, and heat pump market segments are reviewed. Chapter 9.0 discusses the water heater market and respondents' awareness of marketing programs. Detailed statistical discussions of the analysis are included in the appendices. 


\subsection{MAJOR FINDINGS}

This report's objectives are to examine the perceptions, preferences, and fuel switching possibilities for home heating and major appliance fuels. Issues relating to heat pumps and water heater marketing programs are also covered.

\subsection{PERCEPTIONS OF HEATING FUELS}

The respondents were asked to consider eight heating fuel attributes: cost, efficiency, dependability, convenience, safety, cleanliness, comfort, and odor. The large majority of the respondents feel that each of the eight attributes are important for a heating fuel to possess. While very little difference separates the importance ratings of the attributes, the safety of a heating fuel is considered to be the most important attribute. Convenience was rated the least important attribute for a heating fuel to possess. Wood and fuel oil users rated the importance of a nonpolluting fuel lower than respondents did for other heating fuels.

In general, consumers perceived the various heating fuels differently. Overali, across the eight attributes in the study, the respondents perceived electricity in the most positive light, followed by natural gas, wood, and fuel oil. There were no significant differences found between the overall perceptions of wood and fuel $0 i 1$.

Electricity is perceived to be safe, non-polluting, and convenient. However, it is also perceived to be one of the most expensive fuels. Natural gas is perceived to be inexpensive and efficient. It is perceived to provide a more comfortable heat than the other fuels. Its greatest liability is its perceived level of safety. Wood and fuel oil are perceived to be the most polluting fuels. Both of these fuels are not perceived as positively as electricity and natural gas. Fuel oil's greatest liability is the perception of its cost. Wood's greatest liabilities are being inconvenient and not being as safe as the other fuels.

There are differences in the perceptions of the fuels between market segments. Generally, the users of a specific fuel rate their fuel higher in 
terms of the eight fuel attributes. Respondents possessing smart shopper attitudes perceive natural gas to be less safe and less convenient than do other respondents. They also rate the convenience of electricity lower than do other respondents. Differences in the perceptions of the fuels also exist across geographic region and between household life-cycle segments.

The most frequently mentioned reason for using any particular fuel was that the fuel was already installed in the home. The second most frequently mentioned reason was that the fuel was less expensive. Most people do not appear to take an active part in choosing their primary heating fuel, and of those who do, the perceived economy of the fue] is a major reason for using that fuel.

The findings on consumer perceptions of heating fuels and heating fuel attributes are useful in directing utility marketing programs. The attitudes of selected market segments can be modified with promotion strategies to shift their perceptions about a fuel. For example, if the switching of electricity to natural gas is of concern, marketing programs emphasizing the benefits of electricity can be directed to those consumer segments most likely to switch fuels. Marketing could be used to change the perception of electricity as being expensive, or that, like gas, it is efficient.

\subsection{FUEL SWITCHING OF HOME HEATING FUELS}

The potential for fuel switching is examined in terms of the respondents present heating fuel and their preferred heating fuel. From this comparison, the greatest potential for switching is from electricity to natural gas. Natural gas users are the most satisfied with their present heating fuel.

Electricity and natural gas are the two most preferred fuels among the respondents. The most often mentioned reason for preferring any heating fue1, except for electricity, was low cost. The most often reported reason for preferring electricity was the fuel's cleanliness.

Reported past fuel switching indicates that very little fuel switching has occurred. Only six percent of the homeowners surveyed had switched heating fuels in the past two years. Of this six percent, half switched because they changed residences. 
Though little switching of primary heating fuels has occurred, in the long run, a small percentage of homes switching away from electricity each year will lead to electricity losing a large proportion of its market share. Where heating fuel switching is a concern, it is important to carefully study the reasons for customer preference for natural gas and develop a marketing program to begin neutralizing the long term loss of electricity's market share.

Influencing the fuel type of new residences will have the most effect on a fuel's market share in the long run. Since little fuel switching occurs, encouraging the use of electricity in new residences will ensure electricity's long term market share. Comparing the heating fuel type of homes with the year they were constructed indicates a trend towards the increased installation of natural gas as a primary heating fuel. Whereas wood heat experienced a growth in new residence installation during the seventies and the early eighties, it is presently being installed in fewer new homes.

\subsection{A PROFILE OF WOOD USERS}

Forty-nine percent of wood user households consist of adults living together with no children. Most wood users $(68 \%)$ live in Western Washington; the fewest 1 ive in Eastern Oregon/Southern Idaho. Within each region, wood users account for around 17\% of the households, except for Eastern Oregon/ Southern Idaho. Generally, wood users are satisfied with wood heat, however electricity is the most preferred fuel for those not satisfied with wood heat.

The most mentioned reason for wood use is the low cost of the fuel. Sixty-four percent of the wood users gathered all of their wood themselves and the average price per cord for wood users who paid for either gathering it themselves or having it delivered was $\$ 46$. Wood users perceive wood to be more economical, more dependable, safer, more comfortable, more efficient, more convenient, and more pleasing to the sense of smell than do the rest of the respondents. Wood users perceive the fuel to be more polluting than do other respondents, but they rate the importance of a nonpoliuting fuel lower. 
The average amount of wood burned in the 1987-88 heating season was 3.8 cords per household. The wood users reported the amount of wood burned in the 1987-88 was approximately the same amount burned the previous heating season. However, from 1985 to 1987 wood use as a primary heating declined from $29 \%$ to $22 \%$ of households in the Northwest.

The potential of consumers switching to wood from electricity is smaller than the potential for switching to natural gas. Approximately $10 \%$ of those households using electricity prefer wood as a primary heating fuel. Twentythree percent of wood users reported preferring electricity as a primary heating fuel. If the switching of electricity to wood is a concern, the reasons for wood use and the perceptions of the attributes of wood suggest developing a program that emphasized all the costs of using wood, including the non-monetary costs.

\subsection{MAJOR APPLIANCE FUELS}

The predominant fuel for the respondents' cooking stoves, water heaters, and clothes dryers is electricity. Among homeowners, electricity is also the most preferred fuel for these major appliances. Of the three appliances, natural gas is most often used and preferred for water heaters. Twelve percent of the households have a natural gas water heater and $27 \%$ reported preferring a gas water heater.

Fuel switching of major appliances is generally dependent on a change of residence. Thirty-eight percent of the homeowners surveyed had switched their cooking fuels. Sixty-two percent of the responses explaining the reasons for the switch, mentioned building a new home. Another $15 \%$ mentioned the fuel being present when they moved in. of the $25 \%$ of homeowners who switched their water heating fuels, the most often mentioned reason for the switch was the building of a new home ( $64 \%$ of responses) or the fuel already being in the home when they moved in $(16 \%)$.

Most of the fuel switching for cooking and water heating involved switching from natural gas to electricity. For cooking stoves, $78 \%$ of the switchers changed from natural gas to electricity; for water heaters, $61 \%$ of the switchers changed from natural gas to electricity. 


\subsection{HEAT PUMPS}

Only 4\% (27 households) of the homeowners in the sample reported having a heat pump. Eighty-five percent owned an electric heat pump. Most of the heat pump owners are located in Western Washington and Western Oregon, respectively. No heat pump owners were located in Eastern Washington/ Northern Idaho/Western Montana.

Thirty-nine percent of homeowners not owning a heat pump reported being familiar with heat pumps. The familiarity with a heat pump system varied significantly across two of the five segmentation schemes. Homeowners with innovative attitudes and homeowners whose heating fuel is electricity are generally more familiar with heat pumps.

Homeowners that were familiar with heat pumps were asked their likes and dislikes of the system. Thirty-six percent of the responses mentioned the heat pump being efficient, reliable, and providing comfortable heat as likes. Twenty-one percent of the responses included the heat pump being perceived to be less expensive to operate as a advantage. The two most often mentioned dislikes were the same. Thirty-two percent of the responses mentioned the heat pump was not economical and 15\% expressed the inefficiency and lack of reliability of the heat pump as disadvantages.

The low familiarity with heat pumps and the misperceptions about them suggest that a communication program be developed to address two issues: increasing the heat pump awareness of homeowners, and 2) correcting the inaccurate perceptions consumers have about heat pumps.

\subsection{THE WATER HEATER_MARKET AND AWARENESS OF WATER HEATER MARKETING PROGRAMS}

Most people who are in the market for a water heater are replacing a broken water heater or are concerned with the age of their present water heater. Only four percent of the homeowners reported presently being in the market for a water heater, but $26 \%$ of the homeowners' water heaters are over 12 years $01 d$. Only three percent of the homeowners leased their water heaters. 
Awareness of water heater marketing programs was low among the homeowners, even among those presently in the market for a water heater. Only $18 \%$ of the homeowners reported being familiar with a water heater marketing program and of this $18 \%, 35 \%$ did not mentioned a specific program or sponsor, but mentioned utilities, in general, as sponsors. The low awareness of water heater marketing programs and the long replacement $1 \mathrm{ife}$ of water heaters suggest that utilities might consider focusing their resources on marketing programs for retailers and not the final consumer.

Most of the respondents in the survey felt that utilities need to do more than just provide electricity. Seventy-five percent of the respondents felt utilities should offer low-interest loans or rebates for energy conservation investments. Speaking of water heater programs, discounted prices and cash rebates are the most preferred incentives for purchasing a water heater. 


\subsection{DESCRIPTION OF SURVEYED HOUSEHOLDS}

This section introduces the five segmentation schemes that are used to describe the surveyed households; geographic region, primary heating fuel, life-cycle, innovative attitudes, and smart shopper attitudes. Figures 3.1 and 3.2 show the distribution of the primary fuel type within each of the surveyed regions and the geographic distribution of the households surveyed. The geographic region segmentation scheme consists of four regions. The primary heating fuel segmentation scheme consists of four heating fuel types.

The life-cycle segmentation scheme is created using household demographics. Families and singles have different consumer behaviors and attitudes at different stages in their lives. The life-cycle segments describe the households using combinations of the following demographic variables: household size, age of household members, and sex of household members.

A cluster analysis is used to group the households that are most alike on these variables into nine life-cycle segments. The segmentation methodology is discussed in the appendices.
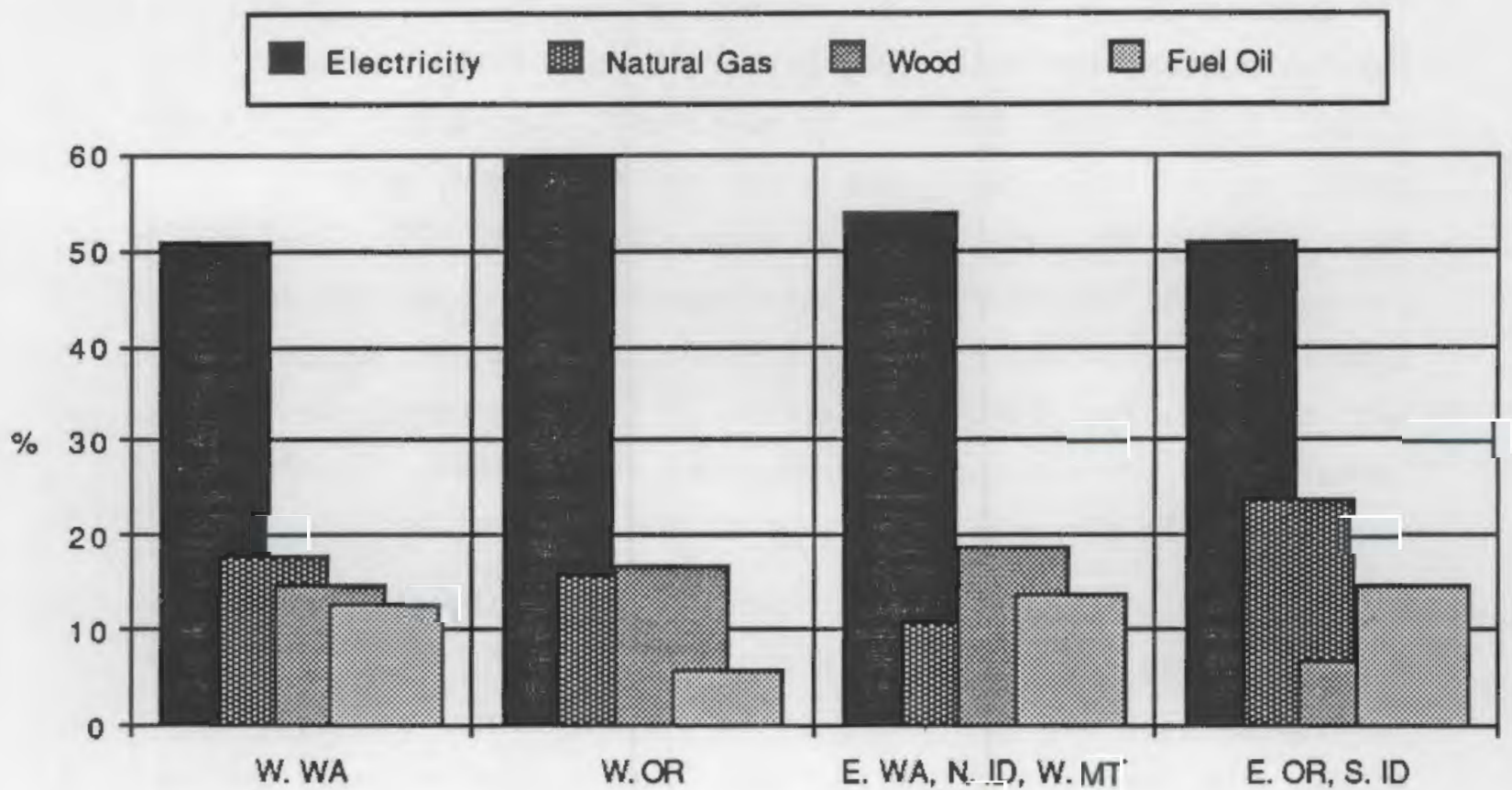

FIGURE 3.1. Primary Heating Fuel Distribution by Region 


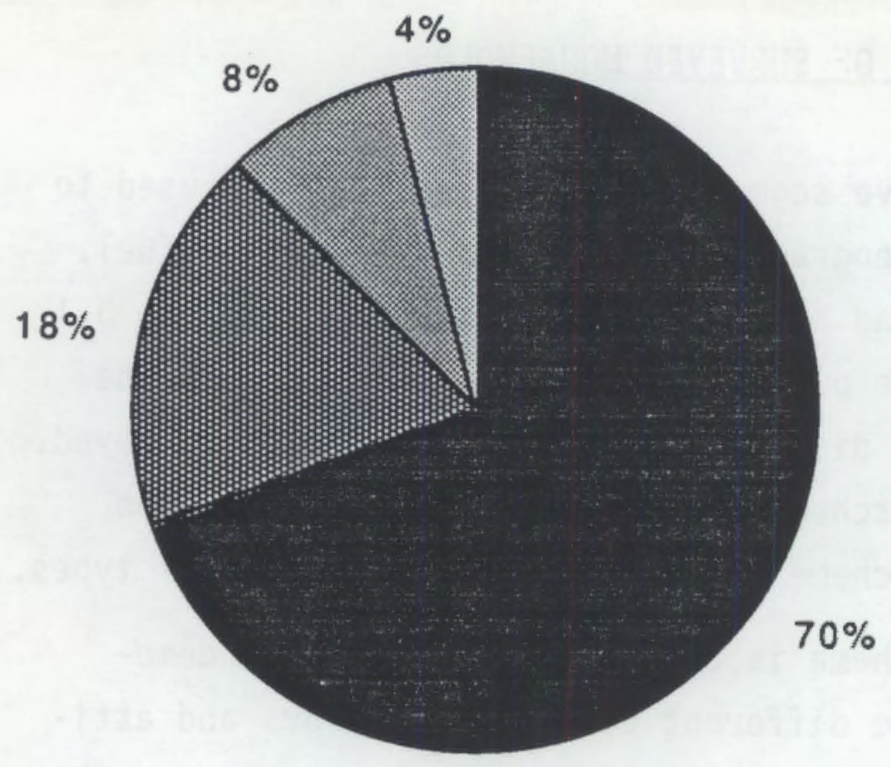

W. WA

W.OR

E. WA, N. ID, W. MT

E. OR, S. ID

FIGURE 3.2. Geographic Distribution of Surveyed Households

The life-cycle segments are described below in terms of the previously mentioned demographic variables, annual household income, highest level of formal adult education, home ownership, and type of residence.

1. Early Career Single Adults (9\%) - consists of single adults between the ages of 21 and 39 . Males account for $54 \%$ of this segment, females account for $46 \%$. They primarily rent their residences (78\%). Accordingly, $64 \%$ live in multi-unit complexes. Thirty percent live in single family dwellings and $4 \%$ in mobile homes. Approximately $77 \%$ have an annual income below $\$ 30,000$. Twenty-nine percent of the respondents in this segment have completed college, another $31 \%$ have completed some college, and $28 \%$ have completed high school only. Forty-two percent of the respondents in this segment have professional or management occupations. Twenty-one percent are in clerical, sales, or service occupations.

2. Middle Age Single Adults (5\%) - consists of single adults between the ages of 40 and 59 . Males account for $54 \%$ of this segment, females account for $46 \%$. They primarily rent their residences (56\%). The largest proportion (48\%) live in single family dwe17ings. Forty percent live in multi-unit complexes and $10 \%$ live in mobile homes. Approximately $60 \%$ have an annual income below 
$\$ 30,000$. Twenty-seven percent have completed college, $21 \%$ have completed some college, and $21 \%$ have completed just high school. Forty percent of the respondents in this segment have professional or management occupations. Twenty-three percent are in clerical, sales, or service occupations.

3. Elderly Single Adults (9\%) - consists of single adults, 60 years of age and over. Males account for $13 \%$ of this segment, females account for $87 \%$. They primarily own their residences $(67 \%)$. The largest proportion (60\%) Tive in single family dwellings. Thirty percent live in multi-unit complexes and $11 \%$ live in mobile homes. Approximately $60 \%$ have an annual income of less than $\$ 15,000$. Twenty-six percent have completed some college, $32 \%$ completed high school as their highest level of education, and $23 \%$ were high school dropouts. Eighty-seven percent of the respondents in this segment are retired. Seven percent work in clerical or sales occupations.

4. Single Parents (4\%) - consists of single adults with children. Male adults account for $28 \%$ of the single parents; whereas, female adults account for $72 \%$ of the single parents. Sixty-three percent of the parents are between the ages of 21 and 35, 44\% between the ages of 36 and 64 , and $2 \%$ over 65 . Twenty-four percent of these households have pre-school children, $37 \%$ have children of primary school age, and $32 \%$ have children of secondary school age. Eighteen percent of the households have older children (18-20) living at home. These households mostly rent their residences (54\%) and primarily live in single family dwellings (56\%) and multi-unit complexes (30\%). Approximately $70 \%$ have an annual household income below $\$ 15,000$. Fifty-one percent just completed high school and 35\% completed some college. The respondents' occupations varied, but the largest percentage $(31 \%)$ were in professional or management occupations.

5. Adults Living Together - No ChiTdren (47\%) - consists of $86 \%$ married adults with no children and $9 \%$ adult roommate households 
( $<100 \%$ due to missing values). Couples between the ages of 21 and 35 make up approximately $30 \%$ of the households in this segment. Couples between the ages of 36 and 64 make up $42 \%$ of the households, and couples 65 years of age and older make up approximately $19 \%$ of the households. Most of the adult roommate households have adults between the ages of 21 and 35 . Sixty-seven percent of households in this segment own their residences and $73 \%$ 1ive in single family dwellings. Forty-four percent of the households have an annual income under $\$ 30,000$. Thirty-five percent have an annual income between $\$ 30,000$ and $\$ 60,000$. Approximately, $36 \%$ of the households have the highest level of adult education being completed some college. Completing high school is the highest level of adult education for $19 \%$ of the households and $18 \%$ have the highest level of adult education in the household being having completed college. Twenty percent of the households have one income. The largest percentage of households has at least one retired person (24\%). Twenty-one percent of the households have at least one person in the professional/management occupations.

6. Late-Family-Stage Households (2\%) - Seventy percent of these households have no children but have three or more adults living together. The majority of the households with children have older children, high school (12-17) or college age (18-21). Of these households, the number of adults is large because a middle aged couple has adult children living in the home. Seventeen percent of the homes also have an elderly adult in them, possibly a grandparent. Approximateiy $13 \%$ of the households consist of 4 roommates with ages from 22 to 35 . Fifty-six percent of the households own. their residence and $87 \%$ live in single family dwellings. Thirty percent have an annual household income between $\$ 30,000$ and $\$ 45,000$. Twenty-six percent have an annual income below $\$ 30,000$. Seventeen percent of the households have one wage earner. In $43 \%$ of the households, having completed some college is the highest 
level of adult education. In $26 \%$, having completed college is the highest level of aduit education. The household occupations encompass almost every category.

7. Middle-Family-Stage Households (19\%) - consists mostly of families with one to two children. Thirty-two percent of the households have pre-school age children, $37 \%$ have children of primary school age, $35 \%$ have children of high school age, and $23 \%$ have children from ages 18 to 21 . Approximately $4 \%$ of the homes have elderly adults, possibly grandparents. Around $36 \%$ of the households are made up of couples between 22 and 35 and $57 \%$ are made up of middle age couples. The largest proportion (33\%) of the households have an annual income between $\$ 15,000$ and $\$ 30,000$. Twenty-two percent have an annual income between $\$ 30,000$ and $\$ 45,000,12 \%$ between $\$ 45,000$ and $\$ 60,000$, and $10 \%$ make over $\$ 60,000$ a year. Thirty-one percent of the households have a single wage earner. The highest level of adult education for $30 \%$ of these households is having completed some college. Twenty-four percent have a highest adult education level of completing high school, $22 \%$ reached the point of completing college, and $8 \%$ completed at least some graduate school. Around $30 \%$ of the households have respondents in the manage$\mathrm{rial} / \mathrm{professional} \mathrm{occupations;} 25 \%$ had clerical/sales/service occupations.

8. Large Nuclear Families (5\%) - consists of couples with at least three children in the home. Sixty-two percent of the households have pre-school age children, $79 \%$ have primary-school age children, $47 \%$ have high school-age children, and $11 \%$ have children between the ages of 18 and 21 . Forty-three percent of the couples are between the ages of 22 and 35 , and $57 \%$ are midd7e-age couples (36-64). Seventy percent of the households own their residence and $74 \%$ live in a single family dwelling. Around $30 \%$ of the households have an annual income between $\$ 15,000$ to $\$ 30,000$ and $30 \%$ between $\$ 30,000$ to $\$ 45,000$. Thirteen percent make below $\$ 15,000$ and between $\$ 45,000$ and $\$ 60,000$. Fifty-three percent of the households have one income. The largest proportion of the households have a 
highest adult education level of completing some college. Nineteen percent have completed high school, $27 \%$ percent have completed college, and $8 \%$ have completed some graduate school. The major occupations are professional/managerial and clerical/sales/service.

To more fully describe the households, two attitude segmentation schemes are developed, the "innovators" and the "smart shoppers." Innovators are those consumers who are more willing to try new products or programs. The smart shoppers are those consumers who shop around for the best deal and who are more interested in quality at a reasonable price. The scales used to segment the households into innovators and smart shoppers are based on the level of agreement with attitude statements and reported product purchase behavior. Those respondents scoring between a 7 and a 10 on the shopper scale are considered to be "smart shoppers." They represent 57\% of the respondents. Those respondents scoring between a 13 and a 20 on the innovator scale are considered to be "innovators." They represent $11 \%$ of the respondents. The development of these scales are fully discussed in the appendices. 


\subsection{PERCEPTIONS OF HEATING FUELS AND THEIR ATTRIBUTES}

Understanding what heating fuel characteristics are important to consumers and how consumers perceive different heating fuels is important in trying to understand the fuel choice decision. The discussions in this section are directed by two hypotheses: 1) Those who use different fuel types place different importance on fuel attributes, and 2) Consumers have different images/perceptions of different heating fuels. This section explores these two issues in terms of eight fuel attributes. The respondents were asked to consider how economical, efficient, dependable, convenient, safe, and nonpolluting specific heating fuels are. In addition, the attributes of providing comfortable heat and not having an offensive odor were considered.

\subsection{PERCEIVED IMPORTANCE OF HEATING FUEL ATIRIBUTES}

The respondents were asked to rate how important it was for a heating fuel to have each of the eight attributes. Table 4.1 shows the percentage of respondents responding to the various levels of importance for each of the attributes. The large majority of the respondents feel that each of the

IABLE 4.1. Respondents' Ratings of Fuel Attributes

\begin{tabular}{|c|c|c|c|c|c|}
\hline \multirow{2}{*}{$\begin{array}{c}\text { Mean } \\
\text { Importance } \\
\text { Rating } \\
\end{array}$} & \multirow[b]{2}{*}{ Attribute } & \multicolumn{4}{|c|}{ Importance of Attributes } \\
\hline & & $\begin{array}{l}\text { Not at al1 } \\
\text { Important }\end{array}$ & $\begin{array}{l}\text { Not Very } \\
\text { Important }\end{array}$ & $\begin{array}{l}\text { Somewhat } \\
\text { Important }\end{array}$ & $\begin{array}{c}\text { Very } \\
\text { Important }\end{array}$ \\
\hline 3.93 & Safe & $1.0 \%$ & $1 \%$ & $6 \%$ & $94 \%$ \\
\hline 3.89 & Dependable & $0.1 \%$ & $1 \%$ & $9 \%$ & $90 \%$ \\
\hline 3.87 & Economical & $0.1 \%$ & $1 \%$ & $10 \%$ & $88 \%$ \\
\hline 3.86 & Efficient & $0.2 \%$ & $1 \%$ & $11 \%$ & $88 \%$ \\
\hline 3.82 & $\begin{array}{l}\text { Not have an } \\
\text { offensive odor }\end{array}$ & $0.6 \%$ & $2 \%$ & $13 \%$ & $85 \%$ \\
\hline 3.80 & $\begin{array}{l}\text { Provide comfortable } \\
\text { heat }\end{array}$ & $0.2 \%$ & $2 \%$ & $16 \%$ & $82 \%$ \\
\hline 3.73 & Non-polluting & $1.0 \%$ & $2 \%$ & $19 \%$ & $78 \%$ \\
\hline 3.71 & Convenient & $0.2 \%$ & $3 \%$ & $22 \%$ & $74 \%$ \\
\hline
\end{tabular}


eight attributes are important for a heating fuel to possess. While very 1ittle difference separates the importance ratings of the attributes, the safety of a heating fuel is considered to be the most important attribute. Convenience is rated the least important attribute for a heating fuel to possess.

The statistical significance of the differences between the importance ratings across the five segmentation schemes was tested (see appendices). The respondents' ratings on the importance of the eight attributes were consistent across four of the five segmentation schemes. While respondents across all the primary heating fuel types thought it important that a fuel be non-polluting, fuel oil users and wood users rated this attribute less important than did electricity and natural gas users. Table 4.2 shows the mean ratings of the importance of a fuel being non-polluting for each primary fuel using group.

\subsection{CONSUMER PERCEPTIONS OF HEATING FUELS}

In the previous section, the importance consumers assigned to different heating fue 7 attributes was examined. This section investigates how respondents perceive the different heating fuels in relation to the eight attributes. Respondent ratings for each of the eight attributes, as well as, their responses to open-ended questions and their level of agreement with attitude statements.

TABLE 4.2. The Importance of a Nonpolluting Heating

Fuel, Ratings by Primary Fuel Type

$\begin{array}{cc}\begin{array}{c}\text { Primary } \\ \text { Fuel Type }\end{array} & \begin{array}{c}\text { Mean } \\ \text { Importance } \\ \text { Rating }\end{array} \\ \text { Natural Gas } & 3.80 \\ \text { Electricity } & 3.76 \\ \text { Fuel 0il } & 3.68 \\ \text { Wood } & 3.60\end{array}$




\subsubsection{Consumer Ratings of Fuel Attributes}

Differences between the overall positive perception of the fuels is examined in this section. The respondents were asked to rate how well each of the eight attributes described four different heating fuels; electricity, natural gas, wood, and fuel oil. For each of the fuels, four of the attributes were worded in the positive and the other four in the negative. The analysis involved reverse coding the negatively worded attributes and examining the difference between the perceptions of the fuels on each of the eight attributes. The statistical significance of the differences in the perceptions of the fuels was tested (see appendices).

Table 4.3 is a pair-by-pair comparison of the mean scores for each fuel attribute on a scale from 1 (Poor Descriptor) to 4 (Good Descriptor). When the overall positive perceptions of the fuels is compared, electricity ranks the highest followed by natural gas, wood, and fuel oil. Comparing the fuels across the individual attributes, either electricity or natural gas consistently score higher than wood and fuel oil. Electricity is perceived to be safer, less polluting, more convenient, and less odorous than natural gas.

TABLE 4.3. Comparison of Means of the Positive Perception Scale, by Fue] Attribute

\begin{tabular}{|c|c|c|c|c|c|c|c|c|c|}
\hline Fuels & LoN Cost & Dependable & Safe & Horpol luting & $\begin{array}{c}\text { Comfor table } \\
\text { Heat }\end{array}$ & Efficient & Convenient & $\begin{array}{l}\text { Ho } \\
\text { offensive } \\
\text { Odor }\end{array}$ & $\begin{array}{l}\text { Overall } \\
\text { Positiye } \\
\text { Image }\end{array}$ \\
\hline $\begin{array}{l}\text { Gas } \\
\text { Elextricity }\end{array}$ & $\begin{array}{l}3.06 * \\
2.13\end{array}$ & $\begin{array}{l}3.21 \\
3.12\end{array}$ & $\begin{array}{l}2.88 * \\
3.37\end{array}$ & $\begin{array}{l}2.98 \\
3.33\end{array}$ & $\begin{array}{l}3.45^{\star} \\
3.33\end{array}$ & $\begin{array}{l}3.236 \\
3.06\end{array}$ & $\begin{array}{l}3.26^{*} \\
3.45\end{array}$ & $\begin{array}{l}2.92^{*} \\
3.60\end{array}$ & $\begin{array}{l}23.22 * \\
24.89\end{array}$ \\
\hline $\begin{array}{l}\text { Gas } \\
\text { Hood }\end{array}$ & $\begin{array}{l}3.06 * \\
2.71\end{array}$ & $\begin{array}{l}3.21 * \\
2.83\end{array}$ & $\begin{array}{l}2.88+ \\
2.27\end{array}$ & $\begin{array}{l}2.98 \\
2.93\end{array}$ & $\begin{array}{l}3.45^{\star} \\
3.02\end{array}$ & $\begin{array}{l}3.23^{*} \\
2.65\end{array}$ & $\begin{array}{l}3.26 \pi \\
1 . \pi 0\end{array}$ & $\begin{array}{l}2.92 \\
2.90\end{array}$ & $\begin{array}{l}23.22^{\circ} \\
20.41\end{array}$ \\
\hline $\begin{array}{l}\text { Gas } \\
\text { oil }\end{array}$ & $\begin{array}{l}3.06 * \\
2.02\end{array}$ & $\begin{array}{l}3.21^{*} \\
2.88\end{array}$ & $\begin{array}{l}2.88 \\
2.81\end{array}$ & $\begin{array}{l}2.98 * \\
2.41\end{array}$ & $\begin{array}{l}3.45^{*} \\
3.11\end{array}$ & $\begin{array}{l}3.23 * \\
2.72\end{array}$ & $\begin{array}{l}3.26 * \\
2.69\end{array}$ & $\begin{array}{l}2.92^{*} \\
2.49\end{array}$ & $\begin{array}{l}23.22 \\
19.65\end{array}$ \\
\hline $\begin{array}{l}\text { Electricity } \\
\text { Hood }\end{array}$ & $\begin{array}{l}2.13^{*} \\
2.71\end{array}$ & $\begin{array}{l}3.12^{\star} \\
2.83\end{array}$ & $\begin{array}{l}3.37 * \\
2.27\end{array}$ & $\begin{array}{l}3.33^{*} \\
2.93\end{array}$ & $\begin{array}{l}3.33^{*} \\
3.02\end{array}$ & $\begin{array}{l}3.06^{*} \\
2.65\end{array}$ & $\begin{array}{l}3.45 \% \\
1.70\end{array}$ & $\begin{array}{l}3.60^{*} \\
2.90\end{array}$ & $\begin{array}{l}24.89 * \\
20.41\end{array}$ \\
\hline $\begin{array}{l}\text { Electricity } \\
\text { of }\end{array}$ & $\begin{array}{l}2.13^{*} \\
2.02\end{array}$ & $\begin{array}{l}3.12 \\
2.88\end{array}$ & $\begin{array}{l}3.37 \\
2.81\end{array}$ & $\begin{array}{l}3.33^{*} \\
2.41\end{array}$ & $\begin{array}{l}3.33 * \\
3.11\end{array}$ & $\begin{array}{l}3.06^{*} \\
2.72\end{array}$ & $\begin{array}{l}3.45^{\star} \\
2.69\end{array}$ & $\begin{array}{l}3.60^{*} \\
2.49\end{array}$ & $\begin{array}{l}24.89 * \\
19.65\end{array}$ \\
\hline $\begin{array}{l}\text { Wood } \\
\text { oil }\end{array}$ & $\begin{array}{l}2.71 * \\
2.02\end{array}$ & $\begin{array}{l}2.83 \\
2.88\end{array}$ & $\begin{array}{l}2.277^{\mathrm{m}} \\
2.81\end{array}$ & $\begin{array}{l}2.93^{*} \\
2.41\end{array}$ & $\begin{array}{l}3.02^{4} \\
3.11\end{array}$ & $\begin{array}{l}2.65^{*} \\
2.72\end{array}$ & $\begin{array}{l}1.70^{*} \\
2.69\end{array}$ & $\begin{array}{l}2.90^{*} \\
2.49\end{array}$ & $\begin{array}{l}20.41 \\
19.65\end{array}$ \\
\hline
\end{tabular}

- Significant at $\leq 0.05$ level.

(a) A fuel's attribute means do not sum to its overall positive image mean due to missing values in the data. 
Natural gas is perceived to cost less, to provide more comfortable heating, and to be more efficient than electricity. The dependability of electricity and natural gas is perceived to be about the same.

According to the consumers' ratings of the attributes for each fuel, fuel oil is perceived to be the most expensive fuel, the most polluting fuel, and the worst smelling fuel. Wood is perceived to be the least safe, to provide the least comfortable heat, to be the least efficient, and to be the least convenient.

\subsubsection{Differences of Fuel Perceptions Across Segments}

An examination of the fuel perceptions across the five segmentation schemes found a number of fuel attributes that are perceived statistically different (see appendices). The primary heating fuel segments have the greatest amount of differentiation between the respondents' perceptions of fuel attributes. Of the eight individual attributes for each of the four fuels, five attributes of electricity and one of fuel oil are similarly perceived across the fue 1 type segmentation. These attributes are safety, cleaniiness (nonpolluting), efficiency, convenience, and non-odorous for electricity and cleanliness for fuel oil.

Table 4.4 presents the fuels and only those attributes that are perceived differently across the heating fuel types. The mean scores on each attribute are shown in the columns; differences between the four heating fuel segments are shown in the rows. For example, the mean rating of wood users for the low cost of wood is underlined in the Table, 3.48. Examining the mean scores in the same row, it is clear that wood users perceive the cost of using wood to be lower than the use of other heating fuels. Generally, the users of a specific fuel rate that fuel higher on possessing the fuel attributes listed than fuels they do not use. They perceive their primary heating fuel in a more positive light than other fuels.

A few other attributes of the different fuels are perceived differently across two more segmentation schemes. The safety and convenience of natura 1 gas and the convenience of electricity are perceived differently between "smart shoppers" and noncomparative shoppers. Also, the cleanliness of wood 
TABLE 4.4. Differences in the Perception of Fuel Attributes, by Heating Fuel Type

\begin{tabular}{|c|c|c|c|c|c|}
\hline \multirow[b]{2}{*}{ Heating Fuel } & \multirow[b]{2}{*}{ Attribute } & \multicolumn{4}{|c|}{ Primary Heating Fuel Seqment } \\
\hline & & Electricity & Natural Gas & Wood & Fuel 0il \\
\hline NATURAL GAS & $\begin{array}{l}\text { Low Cost } \\
\text { Dependable } \\
\text { Safe } \\
\text { Non-Polluting } \\
\text { Comfortable Heat } \\
\text { Efficient } \\
\text { Convenient } \\
\text { No Offensive Odor } \\
\text { Positive Image* }\end{array}$ & $\begin{array}{r}3.03 \\
3.21 \\
2.76 \\
2.93 \\
3.40 \\
3.19 \\
3.17 \\
2.86 \\
22.65\end{array}$ & $\begin{array}{r}3.39 \\
3.40 \\
3.32 \\
3.19 \\
3.68 \\
3.44 \\
3.52 \\
3.17 \\
26.64\end{array}$ & $\begin{array}{r}2.83 \\
3.09 \\
2.78 \\
2.97 \\
3.41 \\
3.12 \\
3.21 \\
2.87 \\
22.73\end{array}$ & $\begin{array}{l}2.88 \\
2.96 \\
2.73 \\
2.83 \\
3.31 \\
3.09 \\
3.23 \\
2.74 \\
19.96\end{array}$ \\
\hline ELECTRICITY & $\begin{array}{l}\text { Low Cost } \\
\text { Dependable } \\
\text { Comfortable Heat } \\
\text { Positive Image }\end{array}$ & $\begin{array}{r}2.27 \\
3.19 \\
3.43 \\
25.60\end{array}$ & $\begin{array}{r}2.00 \\
3.19 \\
3.17 \\
23.86\end{array}$ & $\begin{array}{r}1.90 \\
2.86 \\
3.16 \\
24.20\end{array}$ & $\begin{array}{r}1.94 \\
3.07 \\
3.39 \\
23.90\end{array}$ \\
\hline WOOD & $\begin{array}{l}\text { Low Cost } \\
\text { Dependable } \\
\text { Safe } \\
\text { Non-Polluting } \\
\text { Comfortable Heat } \\
\text { Efficient } \\
\text { Convenient } \\
\text { No Offensive Odor } \\
\text { Positive Image* }\end{array}$ & $\begin{array}{r}2.55 \\
2.77 \\
2.14 \\
2.94 \\
2.94 \\
2.59 \\
1.59 \\
2.90 \\
19.87\end{array}$ & $\begin{array}{r}2.45 \\
2.61 \\
2.15 \\
3.03 \\
2.80 \\
2.49 \\
1.60 \\
2.78 \\
19.23\end{array}$ & $\begin{array}{r}\frac{3.4 B}{3.33} \\
2.78 \\
2.65 \\
3.58 \\
3.08 \\
2.14 \\
3.13 \\
24.06\end{array}$ & $\begin{array}{r}2.59 \\
2.71 \\
2.26 \\
3.13 \\
2.83 \\
2.46 \\
1.55 \\
2.77 \\
19.37\end{array}$ \\
\hline FUEL OIL & $\begin{array}{l}\text { Low cost } \\
\text { Dependable } \\
\text { Safe } \\
\text { Comfortable Heat } \\
\text { Efficient } \\
\text { Convenient } \\
\text { No Offensive Odor } \\
\text { Positive Image }\end{array}$ & $\begin{array}{r}1.89 \\
2.72 \\
2.67 \\
3.01 \\
2.60 \\
2.49 \\
2.41 \\
18.68\end{array}$ & $\begin{array}{r}1.92 \\
3.04 \\
2.79 \\
3.06 \\
2.72 \\
2.74 \\
2.54 \\
19.28\end{array}$ & $\begin{array}{r}2.14 \\
3.13 \\
1.76 \\
2.73 \\
2.77 \\
3.03 \\
2.58 \\
18.25\end{array}$ & $\begin{array}{r}2.72 \\
3.30 \\
3.24 \\
3.53 \\
3.19 \\
3.28 \\
3.02 \\
24.47\end{array}$ \\
\hline
\end{tabular}

and the convenience of fuel oil are perceived differently across the four geographic regions of the survey.

Table 4.5 and 4.6 present the mean attribute scores for each segmentation group. White both "smart shoppers" and noncomparative shoppers 
IABLE 4.5. Mean Scores for Attributes That Are Perceived Differently Between Smart Shoppers and Noncomparative Shoppers

\begin{tabular}{lcc} 
& Smart Shopper & $\begin{array}{c}\text { Non-Comparative } \\
\text { Shopper }\end{array}$ \\
\cline { 2 - 3 } Safety of Natural Gas & 2.82 & 2.97 \\
Convenience of Natural Gas & 3.20 & 3.34 \\
Convenience of Electricity & 3.40 & 3.52
\end{tabular}

IABLE 4.6. Mean Scores for Attributes That Are Perceived Differently Between Regions

\begin{tabular}{|c|c|c|c|c|}
\hline & $\begin{array}{c}\text { Western } \\
\text { Washington }\end{array}$ & $\begin{array}{l}\text { Western } \\
\text { Oregon }\end{array}$ & $\begin{array}{c}\text { Western Montana } \\
\text { Northern Idaho } \\
\text { Eastern } \\
\text { Washington } \\
\end{array}$ & $\begin{array}{l}\text { Southern Idaho } \\
\text { Eastern Oregon }\end{array}$ \\
\hline npolluting, Wood & 2.94 & 2.88 & 3.23 & 2.45 \\
\hline Convenience of Fue $10 i 1$ & 2.75 & 2.42 & 2.80 & 2.58 \\
\hline
\end{tabular}

perceived the attributes of the two fuels in a positive light, the noncomparative shoppers consistently rated the attributes of the two fuels slightly lower. The greatest regional differences in the perception of wood as a nonpoliuting heating fuel is between Eastern Oregon/Southern Idaho and Western Montana/Northern Idaho/Eastern Washington. Using fuel $0 i 1$ is perceived to be the most convenient in Western Montana/Northern Idaho/Eastern Washington and the least convenient in Western Oregon. The respondents' perceptions of a few attributes are also differentiated by 1 ife-cycle segments. Table 4.7 presents the mean scores for each segment's rating of the attributes for the different fuels. While many of the mean scores are very close to each other, there is a pattern between the highest and the lowest mean scores. For almost every attribute presented, Elderly Single Adults have the highest mean scores and Large Nuclear Families have the lowest mean scores. The reason for this result is not clear. These two groups may be distinctly different in the manner in which they perceive fuel attributes or the pattern may be due to a response bias. Elderly people may just not rate anything as critically as those people in large families do. Further investigation is warranted. 
TABLE 4.7. Mean Score for Attributes That Are Perceived Differently, by Life-cycle Segments

\begin{tabular}{|c|c|c|c|c|c|c|c|c|}
\hline & $\begin{array}{l}\text { Early Career } \\
\text { single Adults }\end{array}$ & $\begin{array}{c}\text { Middle Aged } \\
\text { Single Adults } \\
\end{array}$ & $\begin{array}{l}\text { Elderly } \\
\text { Single } \\
\text { Adults } \\
\end{array}$ & $\begin{array}{l}\text { Single } \\
\text { Parents }\end{array}$ & $\begin{array}{l}\text { Adul ts } \\
\text { No Kids } \\
\end{array}$ & $\begin{array}{c}\text { Family } \\
\text { Late } \\
\text { Stage } \\
\end{array}$ & $\begin{array}{l}\text { Fanily } \\
\text { Middle } \\
\text { Stage }\end{array}$ & $\begin{array}{l}\text { Large } \\
\text { Nuclear } \\
\text { Fanilies } \\
\end{array}$ \\
\hline \multicolumn{9}{|l|}{ ELECTRICITY } \\
\hline $\begin{array}{l}\text { Safety } \\
\text { Confortable Heat } \\
\text { Efficiency }\end{array}$ & $\begin{array}{l}3.37 \\
3.45 \\
2.87\end{array}$ & $\begin{array}{l}3.68 \\
3.30 \\
3.04\end{array}$ & $\begin{array}{l}3.64 \\
3.69 \\
3.60\end{array}$ & $\begin{array}{l}3.47 \\
3.30 \\
3.12\end{array}$ & $\begin{array}{l}3.35 \\
3.32 \\
3.05\end{array}$ & $\begin{array}{l}3.14 \\
3.14 \\
3.00\end{array}$ & $\begin{array}{l}3.24 \\
3.26 \\
3.00\end{array}$ & $\begin{array}{l}3.15 \\
3.17 \\
2.83\end{array}$ \\
\hline \multicolumn{9}{|l|}{$\$ 000$} \\
\hline $\begin{array}{l}\text { LOW Cost } \\
\text { FUEL OIL }\end{array}$ & 2.76 & 2.46 & 2.32 & 2.93 & 2.61 & 2.62 & 2.97 & 3.13 \\
\hline $\begin{array}{l}\text { Low Cost } \\
\text { Comfortable Heat } \\
\text { Efficiency }\end{array}$ & $\begin{array}{l}1.98 \\
3.05 \\
2.57\end{array}$ & $\begin{array}{l}1.80 \\
3.14 \\
2.75\end{array}$ & $\begin{array}{l}2.57 \\
3.40 \\
2.98\end{array}$ & $\begin{array}{l}1.91 \\
3.10 \\
2.41\end{array}$ & $\begin{array}{l}2.05 \\
3.15 \\
2.80\end{array}$ & $\begin{array}{l}2.25 \\
3.00 \\
2.78\end{array}$ & $\begin{array}{l}1.90 \\
2.94 \\
2.61\end{array}$ & $\begin{array}{l}1.79 \\
2.91 \\
2.36\end{array}$ \\
\hline
\end{tabular}

\subsubsection{Consumers' Responses to Other Survey Questions}

The rankings of fuel attributes indicated most respondents perceive oil to be the most expensive heating fuel, followed by electricity, wood, and natural gas. Table 4.7 shows the responses to questions about which fuel was perceived to be the most expensive, the least expensive, and the most expensive in 5 years as reported by respondents. While results show some support for the results reported in Section 4.2.1, the support is mixed. As indicated in Figure 4.1, electricity is perceived as the most expensive fuel, followed by fuel oil, natural gas, and wood. From the two reported perceptions, fuel oil and electricity are consistently perceived to be more expensive than natural gas and wood.

The respondents were also asked why they were using their present heating fuel type. Of those respondents living in electrically heated homes, $47 \%$ said they used electricity because "it was already installed in the house (47\% of responses)." Approximately $16 \%$ of the responses were that electricity was less expensive than other fuels. Familiarity, availability, and cleanliness of electricity were each mentioned around $11 \%$ of the time. Other reasons for using electricity were its convenience (6\%) and its efficiency, reliability, and safety $(6 \%)$. 


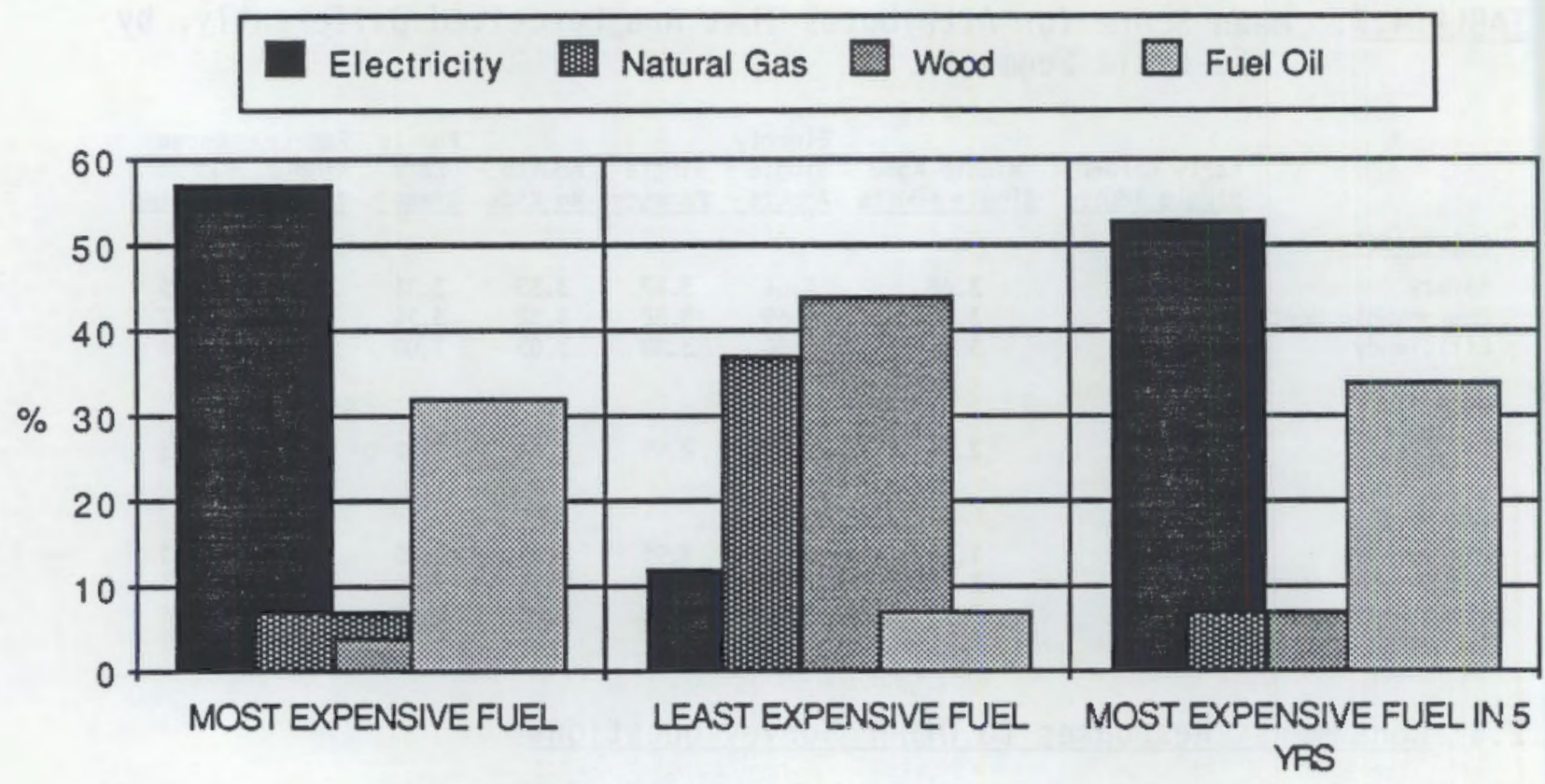

FIGURE 4.1. Perceived Expense by Fuel Type

The reason most mentioned for using natural gas as a heating fuel was that the fuel was already in the home $(36 \%)$. Thirty-four percent of the responses were that natural gas was less expensive than other fuels, $13 \%$ of the responses mentioned that natural gas was a clean fuel, and $9 \%$ of the responses included natural gas' efficiency, reliability, and safety. Other reasons were the respondents' familiarity with natural gas and its convenience.

Wood users most often mentioned that wood was less expensive than other fuels (59\%). Sixteen percent of the responses included the availability of and the familiarity with wood; $10 \%$ of the responses were that wood was reliable, safe, and efficient; and $8 \%$ mentioned that wood was already installed in the house. Only $3 \%$ of the responses included the aesthetics of wood heat as a reason for its use.

For fuel oil heated homes, the primary reason for its use is that it was already installed in the home (55\% of the responses). Twenty-four percent of the responses mentioned that fuel oil is less expensive; $9 \%$ of the responses stated that the respondents' familiarity with and the availability of fuel 
0 il are reasons for their use of fuel 011 ; and $7 \%$ of the responses included the efficiency, safety, and reliability of fuel oil.

The most frequently mentioned reason for using any particular fuel was that the fuel was already installed in the home. The second most frequently mentioned reason was that the fuel was less expensive. Most people do not appear to take an active part in choosing their primary heating fuel, and of those who do, the perceived economy of the fuel is a major reason for using that fuel.

\subsection{AN OVERVIEW OF THE PERCEPTION OF FUELS AND THEIR ATTRIBUTES}

Two hypotheses directed the examination of heating fuels and their attributes: 1) Consumers of different heating fuels place different levels of importance on different attributes and 2) Consumers have different perceptions of heating fuels. Consumers using different heating fuel types do place different importance on fuel attributes, but only for the attribute of being non-polluting. The consumers of electricity and natural gas believe it is more important for a fuel to be non-polluting than the consumers of wood and fuel oil. In general, consumers do perceive the various heating fuels differently. Overal1, across the eight attributes in the study, the respondents perceived electricity in the most positive light, followed by natural gas and wood/fuel oil. There were no significant differences found between the overall perceptions of wood and fuel oil.

Electricity is perceived to be safe, non-polluting, and convenient. It is perceived to be one of the most expensive fuels. Although, when asked their level of agreement with this statement, "Electricity prices are fair when you think about the cost of other things today," approximately $50 \%$ of the respondents strongly agreed or just agreed with the statement.

Natural gas is perceived to be inexpensive and efficient. It is perceived to provide a more comfortable heat than the other fuels. Respondents were asked if natural gas was the energy of the future. About the same number of respondents agreed, disagreed, and were neutral about this statement. The perceived level of safety of natural gas is its greatest liability. When 
asked their level of agreement with, "The safety of natural gas is a concern to me, " close to $60 \%$ of the respondents strongly agreed or just agreed with the statement.

Wood and fuel oil are perceived to be the most polluting fuels. Both of these fuels are not perceived as positively as electricity and natural gas. Fuel oil's greatest liability is the perception of its cost. Wood's greatest liabilities are being inconvenient and not being as safe as the other fuels. 


\subsection{FUEL SWITCHING AMONG HEATING FUELS}

Once consumers have bought into a home, how likely are they to switch their primary heating fuel? The following paragraphs examine the respondents' preferences for heating fuels, the relationship between the respondents' present and preferred heating fuels, past trends in fuel switching, and possible trends in fuel switching among the surveyed households.

\subsection{PREFERENCES FOR HEATING FUELS AND DIFFERENCES ACROSS SEGMENTS}

Electricity and natural gas are the two most preferred heating fuels among the respondents. Approximately $70 \%$ of the respondents stated a preference for either electricity or natural gas. The percentage of respondents preferring each of these two fuels is about 35\%. Fourteen percent of the respondents prefer wood as a heating fuel and $5 \%$ prefer fuel oil. Approximately $5 \%$ of the respondents had no preference.

When asked the reasons for their preference, respondents preferring electricity most often responded that electricity was an environmentally clean fuel and had no undesirable odors (31\% of the responses). Twenty percent of the responses mentioned that electricity provides a comfortable heat that is quick, consistent, safe, and efficient. Less often mentioned reasons for using electricity are its availability and familiarity, its relatively inexpensive cost, and its convenience.

The most often mentioned reason for preferring natural gas as a heating fuel was it is perceived to be more economical (48\% of the responses). The second most often mentioned reason was that natural gas provides a comfortable heat by heating quickly and evenly (20\% of the responses). The convenience of natural gas and its ability to be used as a preferred cooking fuel were reasons mentioned less often.

The respondents that preferred wood over other heating fuels mentioned doing so because wood was less expensive than other fuels (49\% of the responses). The comfort of the heat provided (21\% of the responses) and the aesthetics of burning wood (14\% of the responses) were the next two most often mentioned reasons. Wood's availability was also mentioned. 
of the $5 \%$ of the respondents who preferred fuel $0 i 1$, the largest percentage did so because they felt it was less expensive than other fuels ( $26 \%$ of the responses). Another $26 \%$ of the responses were covered by the respondents stating that fuel oil is available and that they are familiar with fuel 0i1. The comfort of the heat fuel oil provides was also mentioned approximately $26 \%$ of the time.

The statistical tests used to compare the differences in the preferences of heating fuels between the five segmentation schemes are reviewed in the appendices. Differences in the preference of heating fuels exist between geographic regions, primary heating fuel types, and respondents with innovative attitudes.

In Figure 5.1 the heating fuel preferences are shown by geographic region. Electricity is the preferred fuel in three out of four of the regions; the preference for natural gas dominates other fuel preferences in Western Washington.

The respondents' heating fuel preferences are also segmented according to the innovator attitude scales. While the mean scores on the innovator

Electricity Natural Gas Wood

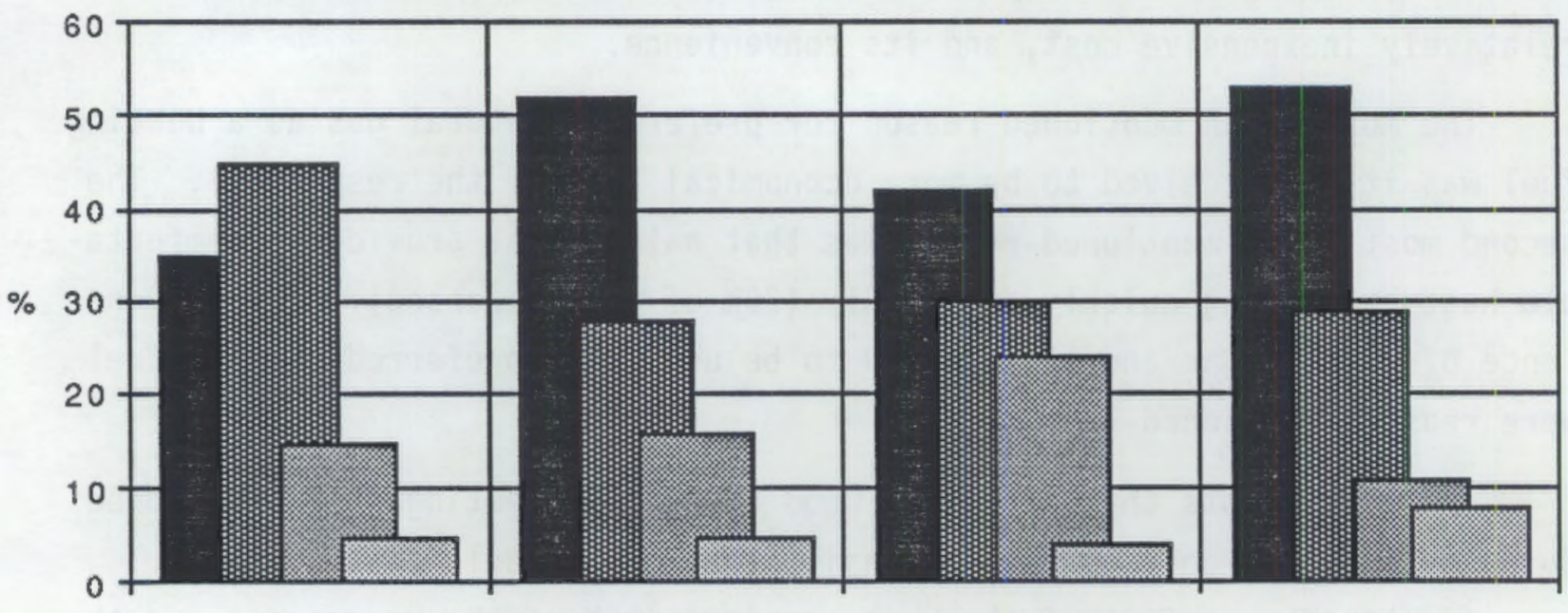

W. WA

W. OR

E. WA, N. ID, W. MT

E. OR, S. ID

FIGURE 5.1. Percentage of Respondents in a Region Preferring a Specific Heating Fuel 
scale for the respondents preferring the different heating fuels cannot be classified as "innovator" scores, those respondents preferring natural gas have the highest mean score on the scale (see Table 5.1).. In other words, respondents preferring natural gas can be said to be more innovative than respondents preferring the other fuel types.

The segmentation of the respondents' preferred heating fuel by their present heating fuel is covered in depth in the following section.

\subsection{PRESENT VERSUS PREFERRED HEATING FUEL}

Figure 5.2 compares the respondents' present heating fuel type with their preferred heating fuel type. This comparison was also made for those respondents who reported having natural gas available. For the most part, the relationship between respondents' present and preferred heating fuel type remains consistent across the availability of natural gas. Natural gas is available for approximately $56 \%$ of the surveyed households.

It appears that those households that use natural gas are the most satisfied with their present heating fuel. Also, according to preference alone, there appears to be more of a potential for electrically heated households to switch to natural gas than for natural gas homes to switch to electricity.

\subsection{PAST AND POTENTIAL FUEL SWITCHING}

Although Figure 5.2 indicates a potential for more homes to switch to natural gas from electricity, the results presented do not take into

\section{TABLE 5.1. Respondents Mean Innovator Score,} by Preferred Heating Fuel

$\begin{array}{lc}\begin{array}{c}\text { Preferred } \\ \text { Heating Fuel }\end{array} & \begin{array}{c}\text { Mean } \\ \text { Innovator Score }\end{array} \\ \text { Electricity } & 8.65 \\ \text { Natural Gas } & 9.25 \\ \text { Wood } & 9.06 \\ \text { Fuel 0il } & 8.76\end{array}$




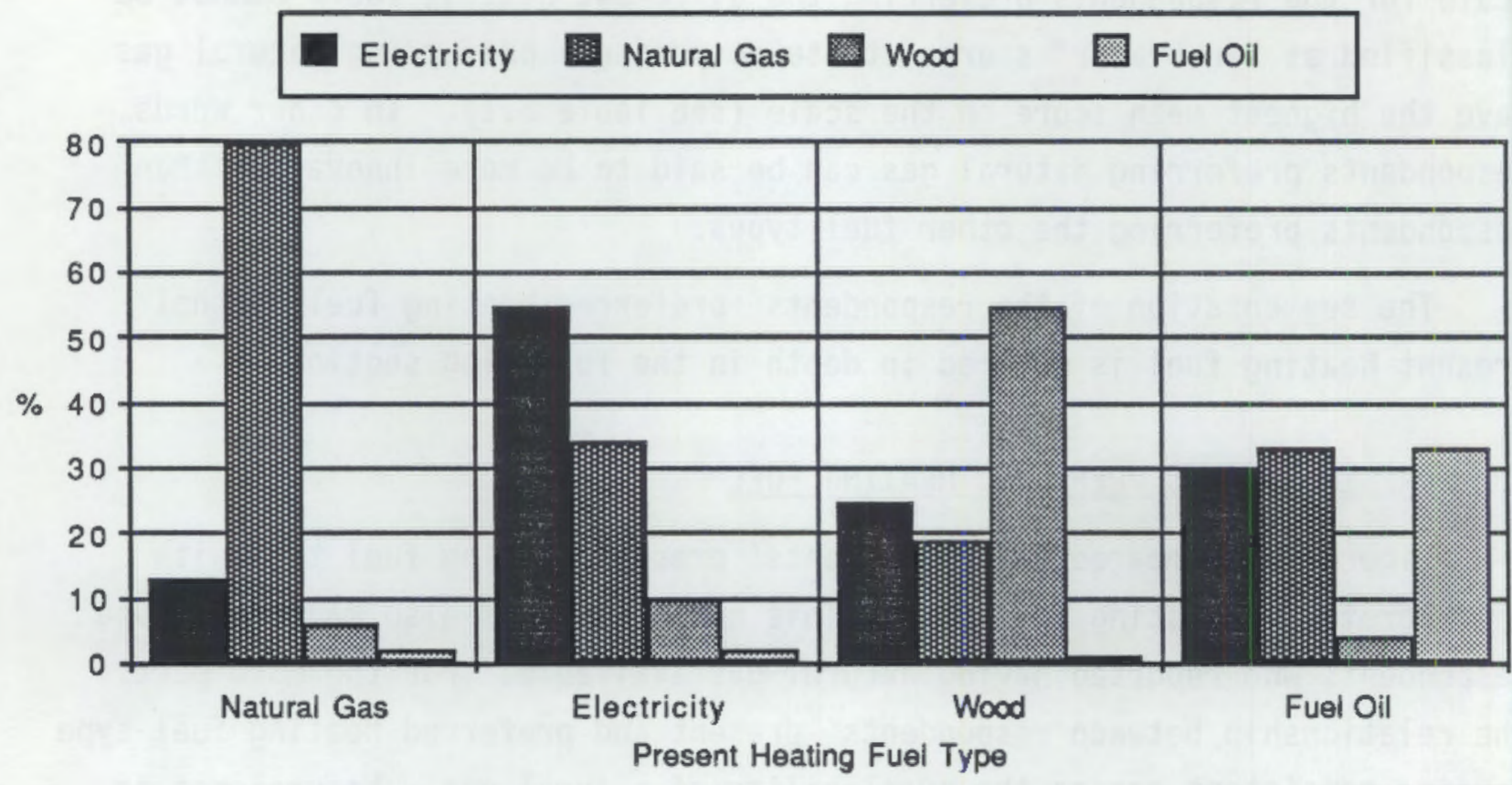

FIGURE 5.2. Respondents' Present Heating Fuel Type Compared With Their Preferred Fuel Type

consideration other factors that may prohibit fuel switching. When asked how likely it was for the household to switch heating fuels in the next two years, only $5 \%$ of the homeowners reported they would consider switching. Another $5 \%$ were unsure. Of those homeowners that have been in their residence longer than two years, approximately $6 \%$ had switched their heating fuels in the past two years. Half of these respondents switched their heating fuels because they changed their residence.

Examining those homeowners who have switched their heating fuel in the past two years, three had switched from electricity to gas, two from electricity to fuel 011 , and three from electricity to wood. Five respondents switched from natural gas: three to electricity, one to fuel oil, and one to wood. Eight respondents switched from fuel oil to other fuels, mostly to natural gas, and four respondents switched from wood, mostly to electricity.

These results indicate that while there may be considerable potential for fuel switching due to fuel preferences, very little actually occurs. The long replacement life of heating furnaces creates a situation where only three to four percent of households replace their furnace in any given year. 
Many homeowners continue to use the same fuel. In this sample, only three percent switched primary heating fuels for reasons other than a change of residence.

Influencing the fuel type of new residences will have the most effect on a fuel's market share in the long run. Since little fuel switching occurs, encouraging the use of electricity in new residences will ensure electricity's long term market share. Figure $\mathbf{5 . 3}$ compares the heating fuel type of homes with the year they were constructed. The figure indicates a trend towards the increased installation of natural gas as a primary heating fuel. Whereas wood heat experienced a growth in new residence installation during the seventies and the early eighties, it is presently being installed in fewer new homes.

Those respondents who had switched heating fuels in the past and those who reported they were likely to switch fuels in the next two years were segmented according to region, primary heating fuel, smart shopper attitudes,

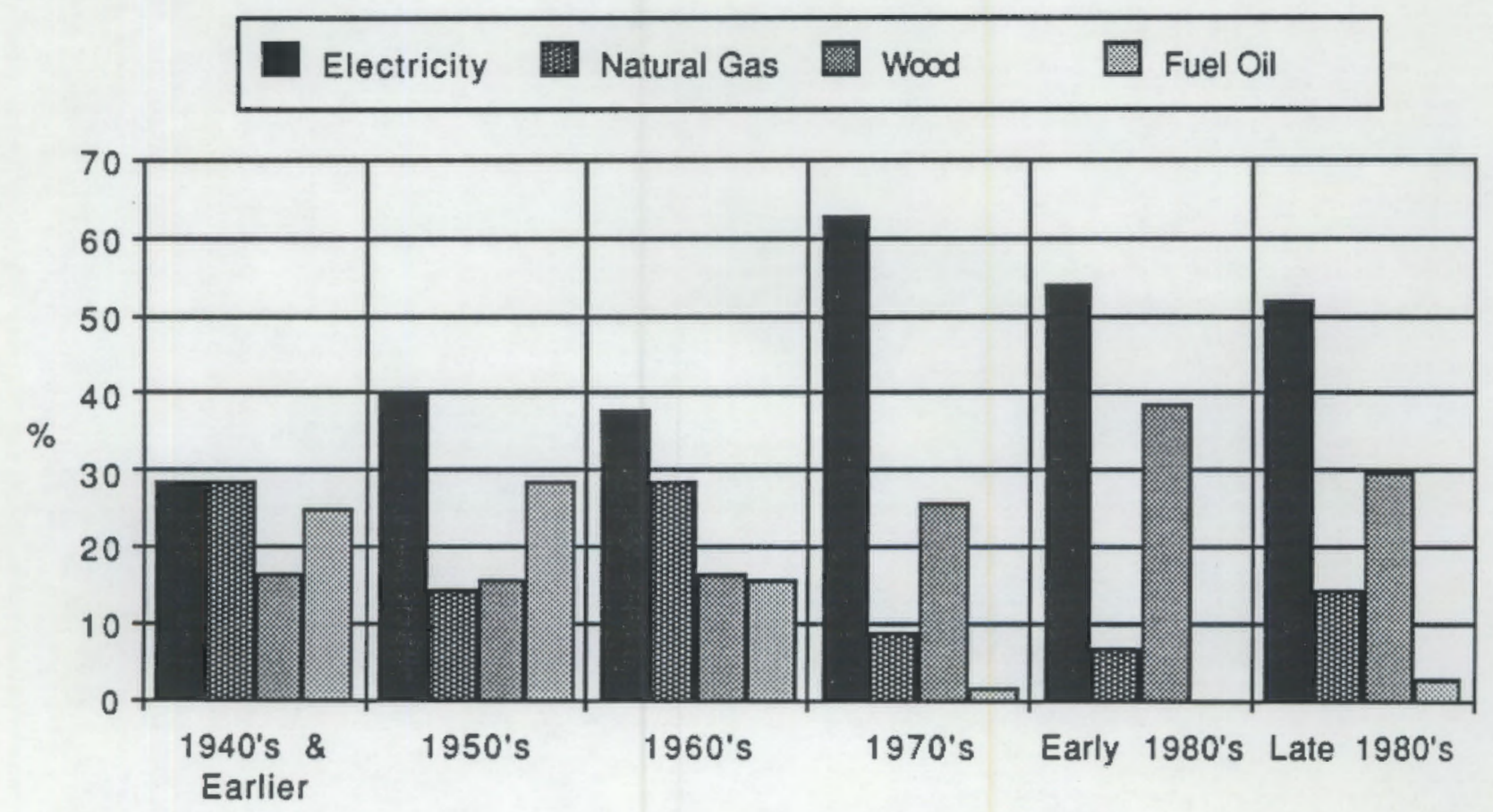

FIGURE 5.3. Respondents' Present Heating Fuel Type Compared With the Vintage of Their Home 
innovator attitudes, and life-cycles. The only statistical differences found between the "switchers" and the rest of the respondents was on the innovator scale scores for those respondents who had switched heating fuels. The mean innovator scale score for fuel switchers is 10.0 , compared with a mean of 8.9 for nonswitchers. Although the mean scores are not high enough to classify the switchers as innovators according to this report's definition, switchers are more innovative than nonswitchers. 


\subsection{WOOD USERS}

According to a 1985 survey of Pacific Northwest households, approximately $29 \%$ of the households were using wood as a primary heating fuel (Ivey et al. 1987). More recently, the Phase III tracking report indicated that wood is the primary heating fuel in $22 \%$ of Pacific Northwest households, but of those households that switched their primary heating fuels, $45 \%$ switched to wood (Schultz 1988). Although wood use appears to be on the decline, it still represents a large segment of the primary heating fuel market and if households switch their primary heating fuel, they are more likely to switch to wood.

This section provides more information about the primary wood users. It investigates wood users' perception of wood, why they use wood, and how much wood they use. The section begins with a description of the households which primarily use wood heat.

\subsection{DESCRIPTION OF WOOD USER HOUSEHOLDS}

Forty-nine percent of wood user households are adult couples or adult roommates with no children. The second and third largest wood user lifecycle segments are households in the middle-family stage with one or two children present (24\%) and large nuclear families with at least three children (11\%). Table 6.1 shows the distribution of wood user households across the life-cycle segments.

According to their scores on the innovator scale, only eight percent are classified as innovators. In this respect, the wood users do not differ from the rest of the respondents. Statistically, their innovator scale scores are not significantly different from the rest of the respondent households. The same holds true for their scores on the smart shopper scale. Approximately $64 \%$ of the wood users are classified as smart shoppers.

In Section 3.0, Figure 3.1 shows the proportion of households using a specific primary heating fuel by region. In three of the four regions, the proportion of wood users is around 17\% (Western Washington; Western Oregon; Eastern Washington/Northern Idaho/Western Montana). Seven percent of the 
TABLE 6.1. Wood Users by Life-cycle Segments

\begin{tabular}{l}
$\frac{1}{\text { Life-Cycle Segment }}$ \\
\hline Early Career Single Adults \\
Middle Age Single Adults \\
Elderly Single Adults \\
Adults - No Kids \\
Single Parents \\
Middle Family Stage \\
Late Family Stage \\
Large Nuclear Families
\end{tabular}

Percent of Wood Users

Early Career Single Adults 3 3 6 49

households in Eastern Oregon/Southern Idaho heat their homes primarily with wood. The largest proportion of wood users (68\%) are located in Western Washington; $20 \%$ are in Western Oregon; $10 \%$ are in Eastern Washington/Northern Idaho/Western Montana; and $2 \%$ are in Eastern Oregon/Southern Idaho.

For the most part, wood users are satisfied with wood as their primary heating fuel. Fifty percent of the wood users stated their preferred fuel was wood. Electricity was the second most preferred heating fuel among wood users, with $23 \%$ preferring it. Approximately $18 \%$ of the wood users would choose natural gas as their primary heating fuel if they had their preference.

\subsection{WOOD USERS' PERCEPTIONS OF HEATING FUELS}

Section 4.2 .2 reports on how the users of the various heating fuels perceive the different heating fuels. As noted, wood users perceived wood differently than did other respondents who did not use wood as a primary heat source. Recapping these results, wood users perceive wood to be less expensive, more dependable, safer, more comfortable, more efficient, more convenient, and more pleasing to the sense of smell than do the rest of the respondents.

A further comparison of wood users' and nonusers perceptions, reveals that wood users perceive natural gas, electricity, and fuel oil to be more expensive than non-wood users do. Interestingly, wood users perceive wood to be more polluting than do non-wood users. Also, wood users perceive electricity to be less dependable and to provide a less comfortable heat. 
Table 6.2 presents only the statistically significant differences between the mean ratings of the fuel attributes of wood users and non-wood users.

\subsection{REASONS FOR WOOD USE AS A PRIMARY HEATING FUEL}

The reasons stated for using wood as a primary heating fuel are covered in Section 4.2 .3 , but are repeated in this section with some additional comments.

Wood users most often mentioned that the reason they use wood is because it is less expensive than other fuels (59\%). The availability of wood and the wood users' familiarity with it was mentioned $16 \%$ of the time as reasons for using wood. Ten percent of the responses from wood users suggested that the reliability, safety, and efficiency of wood heat were reasons for its use. Only $8 \%$ of the responses mentioned that wood being already installed in the house as a reason for its use. Surprisingly, only $3 \%$ of the responses included the aesthetics of wood heat as a reason for its use.

TA8LE 6.2. Mean Ratings of Fuel Attributes for Wood Users and Nonusers

\begin{tabular}{|c|c|c|c|}
\hline Fuel Type & Attribute & Wood Users & Non-Wood Users \\
\hline WOOD & $\begin{array}{l}\text { Low Cost } \\
\text { Dependable } \\
\text { Safe } \\
\text { Non-Polluting } \\
\text { Comfortable Heat } \\
\text { Efficient } \\
\text { Convenient } \\
\text { No Offensive Odor } \\
\text { Positive Image }\end{array}$ & $\begin{array}{r}3.48 \\
3.33 \\
2.78 \\
2.65 \\
3.58 \\
3.08 \\
2.14 \\
3.13 \\
24.06\end{array}$ & $\begin{array}{r}2.50 \\
2.70 \\
2.16 \\
2.98 \\
2.90 \\
2.56 \\
1.61 \\
2.85 \\
19.67\end{array}$ \\
\hline NATURAL GAS & Low Cost & 2.83 & 3.10 \\
\hline ELECTRICITY & $\begin{array}{l}\text { Low Cost } \\
\text { Dependable } \\
\text { Comfortable Heat } \\
\text { Positive Image }\end{array}$ & $\begin{array}{r}1.90 \\
2.86 \\
3.16 \\
24.20\end{array}$ & $\begin{array}{r}2.17 \\
3.16 \\
3.37 \\
25.02\end{array}$ \\
\hline FUEL OIL & $\begin{array}{l}\text { Low Cost } \\
\text { No Dffensive Odor } \\
\text { Positive Image }\end{array}$ & $\begin{array}{r}1.76 \\
2.23 \\
18.25\end{array}$ & $\begin{array}{r}2.06 \\
2.54 \\
19.88\end{array}$ \\
\hline
\end{tabular}


The wood users were asked under what circumstances they would use less wood and rely more on their secondary heating systems. Twenty-seven percent of the responses to this question stated that a lack of wood or an increase in wood prices would cause them to use their secondary heating system more. Nineteen percent of the responses stated that a reduction in the cost of their backup fuels would prompt them to use less wood. These responses and the most mentioned reason for using wood indicate that wood users, as a whole, are more concerned with the cost of their heating fuels than with any other attributes.

Fourteen percent of the wood users are hard core wood users and stated they could think of no circumstances that would prompt them to use less wood. other circumstances mentioned were a change in the weather $(11 \%)$, becoming to lazy to use wood (10\%), becoming physically unable to use wood $(10 \%)$, and making energy improvements to home and backup system (5\%). Approximately $2 \%$ mentioned the air pollution factor as a reason to use less wood.

\subsection{AMOUNT OF WOOD USED FOR HEATING}

Accurate estimations of how much wood users use are difficult to obtain. Self report estimations rely on the respondents recollection and definition of an amount of wood. The survey was fielded in March of 1988. The survey asked the wood users how many cords of wood they expected to burn during the present heating season. A cord was defined as a stack of wood that measures $4 \mathrm{ft} . \times 4 \mathrm{ft} . \times 8 \mathrm{ft} ., 128$ cubic feet, or roughly a standard-size pickup $10 a d$ stacked $3 \mathrm{ft}$. high. The wood users were also asked if they had burned more, less, or the same amount of wood for the 1986-87 and 1987-88 heating season.

For the 1987-88 heating season, the average amount of wood burned by a wood user household was 3.8 cords. Thirty-three percent of wood users reported using 3 cords of wood for the 1987-88 heating season. Eighty-three percent of the wood users reported using between 2 and 5 cords. Thirteen percent of the wood users used more than 5 cords during the 1987-88 heating season. The large majority of the wood users (64\%) gathered $100 \%$ of the wood they used for the 1987-88 heating season and 26\% purchased and had their wood delivered. The average price per cord for the wood users who paid for either 
gathering it themselves or having it delivered was $\$ 46$. Fifty-six percent of the wood users paid nothing for their wood.

No support was found for the hypothesis; the amount of wood burned by wood users has declined since the 1985/86 heating season. Eighty-one percent of the wood users responded that the amount of wood they burned this year was about the same as last year (1986-87 heating season). Approximately $12 \%$ burned less wood this season and $9 \%$ burned more wood. From these responses it is difficult to draw the conclusion that the amount of wood burned by wood users has decreased.

of those wood users who burned more wood this year, half did so because of colder temperatures. The other half did so because they installed a different heating system between the two years or because they increased the amount of space that needed heating. Of those wood users who burned less wood this year, $71 \%$ did so due to milder temperatures, $14 \%$ did so due to spending less time at home, and $7 \%$ did so due to less wood being available. Seven percent of the wood users gave no reason for burning more or less wood. 


\subsection{APPLIANCE FUEL CHOICE}

The previous sections have reported on the respondents use, preferences, and perceptions of heating fuels. Although a large portion of energy is consumed in home heating, energy is also consumed by household appliances. Three appliances, the stove/range, water heater, and clothes dryer, are discussed in this section. Each of these appliances can use fuels other than electricity. Section 7.0 covers the respondents present appliance fuels, their preferred appliance fuels, and appliance fuel switching.

\subsection{PRESENT AND PREFERRED APPLIANCE FUELS}

Most of the surveyed households use electricity for their appliances. For their cooking fuel, $93 \%$ of the respondents use electricity. Five percent of the respondents use natural gas for cooking. Two other cooking fuels that were mentioned are wood and propane. Households with electric water heaters make up $86 \%$ of the surveyed households. Twelve percent of the households have gas water heaters. Another $2 \%$ of the households use either fuel oil or propane for their water heating fuels. Thirteen percent of the households surveyed did not have a clothes dryer. Of those homes which have clothes dryers, $97 \%$ have an electric clothes dryer. The rest of the households have clothes dryer fueled by natural gas.

Most of the respondents who own their homes also prefer electricity for their appliances. Seventy-five percent of homeowners prefer electricity as a cooking fue $1,20 \%$ prefer natural gas, and $5 \%$ prefer other fuels such as wood or propane. For water heating fuels, $66 \%$ of homeowners prefer electricity, $27 \%$ prefer natural gas, and $5 \%$ have no preference. Solar, propane, and oil are preferred water heating fue $1 \mathrm{~s}$ for $2 \%$ of the homeowners. Electricity, as a fuel for a clothes dryer, is preferred by $82 \%$ of the homeowners. Eleven percent of the homeowners prefer natural gas as a fuel for their clothes dryer. Seven percent of the homeowners prefer drying their clothes in the sun.

The most often recited reason for preferring a specific cooking fuel was that the fuel was already installed in the home and their used to it. 
Thirty-two percent of those homeowners preferring electricity for cooking did so for just this reason. Only $4 \%$ of those homeowners preferring natural gas for cooking did so for this reason. Table 7.1 lists the reasons for preferring a specific cooking fuel. Homeowners who cook with natural gas seem to perceive their fuel to be more economical, easier to cook with, more convenient, and more efficient/dependable than do those homeowners who cook with electricity.

When homeowners' present and preferred appliance fuels are compared across the five segmentation schemes, the only statistically significant pattern is the homeowners' present appliance fuels compared to their primary heating fuels. This topic is discussed in the next section.

\subsection{APPLIANCE FUEL SWITCHING}

The potential for switching appliance fuels is discussed in terms of the potential for mixed fuel homes, in terms of the homeowners' present and preferred appliance fuels, and in terms of past appliance fuel switching among the homeowners.

In Table 7.2 homeowners' primary heating fuel is compared with their present appliance fuels. The table gives an indication of the potential for

TABLE 7.1. Homeowners' Reasons for Preferring a Cooking Fuel, by Preferred Cooking Fuel

\begin{tabular}{lccc}
\multicolumn{1}{c}{ Reasons } & \multicolumn{2}{c}{ Cooking Fuel } \\
\cline { 1 - 1 } Already installed/Used to it & & $32 \%$ & Natural Gas \\
Easier to cook on & $1 \%$ & $4 \%$ \\
Economical & $3 \%$ & $12 \%$ \\
Available & $8 \%$ & $16 \%$ \\
Cleaner/Pollution factor & & $11 \%$ & $1 \%$ \\
Convenient/No hassle & & $15 \%$ & $5 \%$ \\
Efficient/Dependable & & $20 \%$ & $25 \%$ \\
Other & $10 \%$ & $32 \%$ \\
& & $5 \%$
\end{tabular}


TABLE 7.2. Homeowners' Primary Heating Fuel by Appliance Fuels

\begin{tabular}{|c|c|c|c|c|c|c|c|}
\hline \multirow{2}{*}{$\begin{array}{l}\text { Primary } \\
\text { Heating Fuel }\end{array}$} & \multicolumn{3}{|c|}{ Cooking Fuel } & \multicolumn{2}{|c|}{$\begin{array}{c}\text { Water } \\
\text { Heating Fuel } \\
\end{array}$} & \\
\hline & Electricity & Gas & Other & Electricity & Gas & Electricity & Gas \\
\hline Electricity & $98 \%$ & $2^{\circ} \%$ & & $98 \%$ & $2 \%$ & $100 \%$ & \\
\hline Natural Gas & $80 \%$ & $20 \%$ & & $43 \%$ & $57 \%$ & $89 \%$ & $11 \%$ \\
\hline Wood & $95 \%$ & $2 \%$ & $3 \%$ & $95 \%$ & $5 \%$ & $97 \%$ & $3 \%$ \\
\hline Fuel $0 i l$ & $98 \%$ & $2 \%$ & & $100 \%$ & & $99 \%$ & $1 \%$ \\
\hline
\end{tabular}

appliance fuel switching in homes where the other fuel already exists, therefore making the switch easier to complete. A small percentage of households have a mixture of appliance and primary heating fuel types. For mixed fuel homes, electricity dominates natural gas in the percentage of homes that use electricity for their cooking and clothes drying fuels. Natural gas dominates electricity for water heating in mixed fuel homes. There appears to be a strong potential for switching away from electric water heaters in mixed fuel homes.

Comparing preferred appliance fuels with present appliance fuels provides more insight into the potential for appliance fuel switching than reporting percentages of preference. In Tables $7.3,7.4$, and 7.5 homeowners' preferred appliance fuel is compared with their present appliance fuel for

TABLE 7.3. Present Cooking Fuel Compared with Preferred Cooking Fuel

Present Cooking Fuel

Electricity

Natural Gas
Preferred Cooking Fuel

\begin{tabular}{cc}
\hline Electricity & Natural Gas \\
\hline $78 \%$ & $19 \%$ \\
$25 \%$ & $75 \%$
\end{tabular}

No Preference

$3 \%$

$0 \%$

TABLE 7.4. Present Water Heating Fuel Compared With Preferred Water Heating Fue?

\begin{tabular}{|c|c|c|c|}
\hline $\begin{array}{l}\text { Present Water } \\
\text { Heating Fuel } \\
\end{array}$ & $\begin{array}{l}\text { Preferred } \\
\text { Electricit }\end{array}$ & $\frac{\text { Heating Fuel }}{\text { Natural Gas }}$ & No Preference \\
\hline Electricity & $77 \%$ & $17 \%$ & $6 \%$ \\
\hline Natural Gas & $10 \%$ & $88 \%$ & $2 \%$ \\
\hline
\end{tabular}


TABLE 7.5. Present Clothes Dryer Fuel Compared With Preferred Clothes Dryer Fuel

Present

Clothes Dryer Fuel

Preferred Clothes Dryer Fuel

Electricity E]ectricity Natural Gas

$86 \%$

$9 \%$

No Preference

Natural Gas

$18 \%$

$82 \%$

6\%

$0 \%$

stoves, water heaters, and clothes dryers. The tables demonstrate that homeowners are generally satisfied with their present appliance fuels. All three tables present resuits that are statistically significant.

Although most of the homeowners are satisfied with their present appliance fuels, there appears to be some potential for switching appliance fuels. Everything else being equal, it appears that, given the opportunity, homeowners would switch to their preferred appliance fuels. In the real world, homeowner preference is just one of the influences on the fuel choice decision and the actual potential for switching appliance fuels is probably smaller than that is indicated in Tables 7.3, 7.4, and 7.5. For this reason, the past appliance fuel switching behavior of the homeowners is examined. of the 610 homeowners surveyed, $151(25 \%)$ had switched their water heating fuel and 231 (38\%) had switched their cooking fuel. Table 7.6 presents the past fuel switching of homeowners for their cooking and water heating fuels. The percentages reported in the table are of those homeowners who reported switching their cooking or water heating fuel. The percentages do not include all homeowners.

TABLE 7.6. Homeowner Switching of Cooking and Water Heating Fuels

\begin{tabular}{|c|c|c|c|c|c|c|}
\hline \multirow[b]{2}{*}{ Present Fuel } & Cooking Fuel & \multirow{2}{*}{$\begin{array}{c}\text { Switched } \\
\text { Natural } \\
\text { Gas } \\
\end{array}$} & \multirow{2}{*}{$\begin{array}{l}\text { Fron } \\
\text { Other } \\
\text { Fuels }\end{array}$} & \multicolumn{3}{|c|}{ Water } \\
\hline & Electricity & & & Electricity & $\begin{array}{l}\text { Natural } \\
\text { Gas } \\
\end{array}$ & $\begin{array}{l}\text { Other } \\
\text { Fuels }\end{array}$ \\
\hline Electricity & $0 \%$ & $78 \%$ & $13 \%$ & $0 \%$ & $61 \%$ & $7 \%$ \\
\hline Natural Gas & $6 \%$ & $0 \%$ & $1 \%$ & $29 \%$ & $0 \%$ & $1 \%$ \\
\hline Other & $1 \%$ & $1 \%$ & $1 \%$ & $0 \%$ & $0 \%$ & $0 \%$ \\
\hline
\end{tabular}


The homeowners were asked if they had ever switched their cooking fuel or water heater fue1. Thirty-eight percent of the homeowners surveyed had switched their cooking fuels. Of this $38 \%, 78 \%$ switched from natural gas to electricity while $6 \%$ switched from electricity to natural gas. Those switching from natural gas to electricity mentioned building a new home as the primary reason for switching ( $62 \%$ of the responses). Fifteen percent of the responses mentioned that the fuel was already in the home when they moved in as a reason why they switched cooking fuels. Other reasons mentioned less frequently were that electricity was cleaner $(4 \%)$, easy to operate $(3 \%)$, and safer $(3 \%)$. Those that switched from electricity to natural gas mentioned building a new home as the primary reason for their change of cooking fuels (22\% of the responses). Another $22 \%$ mentioned that the fuel was already in the home as a reason for changing their cooking fuels. Other reasons mentioned were that natural gas is easier to operate $(6 \%)$ and cheaper $(11 \%)$.

Twenty-five percent of the homeowners surveyed had switched water heating fuels. Of the $25 \%, 61 \%$ switched from natural gas to electricity and $29 \%$ from electricity to natural gas. Those that switched from natural gas to electricity most often mentioned building a new home (64\% of the responses) and the fuel already being in the home when they moved in (16\%) as the reasons for their switch. Other reasons mentioned were recovery time, costs, and availability. Those that switched from electricity to natural gas most often mentioned building a new home as the reason for switching water heating fuels (33\% of the responses). Twenty-four percent of the responses mentioned that the fuel was already in the home, $20 \%$ mentioned that gas cost less than electricity, and $14 \%$ of the responses mentioned that gas water heaters had a faster recovery time as a reason for switching to natural gas.

Assuming that those homeowners who said they had their residence built actually chose their cooking and water heating fuels, the potential for homeowners actively deciding to switch to their preferred fuels is dependent on a change of residences. The botton line is that homeowners are willing to switch to their preferred fuels, but mostly for new residences. Few will retrofit old homes to get their preferred fuels. 
The likelihood of homeowners switching all their appliances and their heating system if they switched to their preferred cooking fuel was investigated. A logical assumption, following from the previous discussion is that few homeowners would change their heating and appliance fuels completely without moving to a new residence. However, to examine this possible situation, the homeowners were asked the question in a hypothetical sense. Homeowners who did not have their preferred cooking fuel but had their preferred cooking fuel available were asked what the likelihood was that they would switch their present appliances and their heating system to their preferred cooking fuel type, assuming that they were going to switch their cooking fuel.

The situation described above included very few homeowners out of the entire sample. Only 35 homeowners did not have their preferred cooking fuel and reported their preferred cooking fuel being available. Only 29 homeowners (5\% of the homeowners) in the sample had electricity with which to cook yet preferred natural gas. Assuming these homeowners switched to natural gas for cooking, eleven reported being very likely to switch the rest of their appliances to natural gas, eight somewhat likely, four not very likely, five not at all likely, and one being unsure. All of the six homeowners having natural gas and preferring electricity for cooking were unsure or refused to answer how likely they were to switch their other appliances. Only one homeowner reported being very likely to change heating fuels assuming changing cooking fuels. The rest of the 35 were unsure or refused to answer.

The small sample size of this specialized situation makes it difficult to draw any conclusions. If this area needs to be investigated more thoroughly, a study designed strictly to investigate the topic should bring more conclusive results.

To help describe those homeowners that have switched either their cooking fuel or their water heating fuel, the data were examined for differences between switchers and nonswitchers across the five segmentation schemes. The only significant difference that exists is between the mean innovator scale 
score for switchers and nonswitchers. Although neither group can be classified as innovators by the scale, the appliance switchers are more innovative than nonswitchers, hence their switching of fuels. To prevent or encourage the switching of appliance fuels, efforts can be targeted towards innovative homeowners. 



\subsection{OWNERSHIP, FAMILIARITY, PERCEPTIONS, AND PURCHASE INTENT OF HEAT PUMPS}

Diverging from the fuel issue, the remaining two sections of the report are concerned with the heat pump and water heater markets. This section develops a picture of the heat pump market in terms of heat pump ownership, familiarity with heat pumps, perceptions of heat pumps, and the respondents' reported likelihood of purchasing a heat pump. It is difficult to draw any strong conclusions about the heat pump owners because there were only 27 in the sample. To provide better information concerning heat pump owners, another study designed to address just heat pump owners would be appropriate.

\subsection{HEAT PUMP OWNERS}

The purpose of this section is to describe heat pump owners in terms of the five segmentation schemes. Statistical1y, heat pump owners were found to be no different than non-owners across the five segmentation schemes. Respondents were asked what type of heating equipment they currently used in their homes; a total of 27 respondents ( $2 \%$ of the sample) said they had either an electric or gas heat pump.

Tab7e 8.1 shows the characteristics of the heat pump owners. Fifty-nine percent of the heat pump owners live in Western Washington, $30 \%$ live in

TABLE 8.1. Heat Pump Owners by Segmentation Schemes ( $N=27$ )

\section{Attitude}

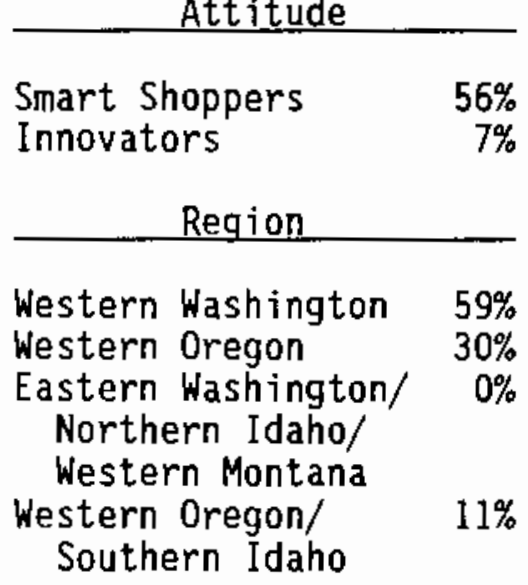

Life-cycle

Middle Aged Single Adults $4 \%$ Elderly Single Adults $\quad 11 \%$ Single Parents $\quad 11 \%$ Adults - No Children $\quad 56 \%$ Middle Family Stage $\quad 19 \%$ Large Nuclear Families $\quad 5 \%$ Primary Heating Fue?

Electricity Natural Gas
$85 \%$

$15 \%$ 
Western Oregon, and the rest live in Eastern Washington/Northern Idaho/ Western Montana. The largest heat pump markets are in Western Washington and Western Oregon where the $\mathrm{cl}$ imate is better suited for a heat pump and where there are more people. The largest group of homeowners purchasing heat pumps are those couples without any children, but households in various family stages make up $24 \%$ of heat pump owners. Electrical heat pumps dominate the market due to the availability and widespread use of electricity.

\subsection{HOMEOHNER'S LEVEL OF FAMILIARITY WITH HEAT PUMPS}

Only 4\% of the homeowners in the sample own a heat pump. The homeowners who did not own one were asked whether they would classify themselves as being very, somewhat, not very, or not at all familiar with heat pump systems. Nine percent of the homeowners reported being very famitiar with heat pumps and $30 \%$ reported being somewhat familiar with heat pumps.

To verify the respondents' self-reported familiarity with heat pump systems, the respondents were also asked if a heat pump also cools. As would be expected, the relationship was significant: $100 \%$ of those who were very familiar, $93 \%$ of those who were somewhat familiar, $82 \%$ of those who were not very familiar, and only $46 \%$ of those who were not at all familiar with heat pumps said they were aware of the heat pump's cooling capability. The results suggest that the self-reporting in this instance is fairly accurate. They also suggest that a heat pump's ability to cool a home should be stressed in any educational or promotional program for heat pumps.

The homeowners' level of familiarity with heat pumps varies significantly across two segmentation schemes. Table 8.2 shows these differences. Innovative homeowners and homeowners who primarily heat with electricity are more familiar with heat pumps than are noninnovators and other primary heating fuel users. One would expect innovative homeowners to know more about technologies such as the heat pump. Although heat pumps can use electricity or natural gas, electric heat pumps are the better known and most used. Users of other primary heating fuels know little about heat pumps probably 
TABLE B.2. Familiarity with Heat Pumps, by Segmentation Schemes

\begin{tabular}{lccccc}
$\begin{array}{c}\text { Present } \\
\text { Heating Fuel }\end{array}$ & \multicolumn{4}{c}{ Familiarity with } & Heat Pump Systems \\
\cline { 2 - 6 } Eery & Somewhat & Not Very & Not At All \\
Electricity & $17.3 \%$ & $30.8 \%$ & $23.7 \%$ & $28.2 \%$ \\
Natural Gas & $10.3 \%$ & $28.4 \%$ & $25.0 \%$ & $36.2 \%$ \\
Fuel 0i1 & $3.3 \%$ & $32.2 \%$ & $20.0 \%$ & $44.4 \%$ \\
Wood & $10.8 \%$ & $23.8 \%$ & $26.9 \%$ & $38.5 \%$ \\
Attitude & & & & \\
Innovators & $23.2 \%$ & $37.7 \%$ & $15.9 \%$ & $23.2 \%$
\end{tabular}

because heat pumps cannot be used with their fuel type. Targeting educational and promotional heat pump programs towards fuel oil users and wood users may pay off when these homeowners are retrofitting or changing residences.

\subsection{HOMEOWNERS PERCEPTIONS OF HEAT PUMPS}

Only those respondents who own a heat pump or stated they were very familiar or somewhat familiar with heat pump systems were asked what they liked and disliked about heat pumps. These homeowners were also asked if the opportunity arose, would they purchase a heat pump again and the reasons why or why not. Tables 8.3 and 8.4 contain results for the questions regarding likes and dislikes about heat pumps.

TABLE 8.3. What Homeowners Like About Heat Pumps

\begin{tabular}{|c|c|}
\hline Response & Percent \\
\hline Efficient/Reliable/Even Heat/Not Dry Heat & 36 \\
\hline Less Expensive/More Economical & 21 \\
\hline Heats \& Cools - Versatile & 20 \\
\hline Clean quite environmentally sound & 6 \\
\hline Convenient & 5 \\
\hline Other & 0 \\
\hline Don't Know/Nothing & 12 \\
\hline
\end{tabular}


TABLE 8.4. What Homeowners' Dislike About Heat Pumps

\begin{tabular}{lcc}
\multicolumn{1}{c}{ Response } & Percent \\
\cline { 1 - 1 } Expensive/Not Economical & & 32 \\
Inefficient/Unreliable/ & 15 \\
$\quad$ Doesn't Work Well in Cold & \\
Noisy/Ugly & 9 \\
Prone to failures/Short Lifespan & 7 \\
Complicated/Hassle to Install & 1 \\
Other & 3 \\
Don't Know/Nothing & 33
\end{tabular}

Of the homeowners who own or are familiar with a heat pump, $43 \%$ percent of those who responded said they would purchase a heat pump if they were to purchase another heating system for their next home. Twenty-seven percent said "no" and 30\% were "unsure". For those who said they would purchase a heat pump the four reasons most often mentioned for their decision were

$\begin{array}{lr}\text { Efficient/Heats Faster/Even Heat } & 39.6 \% \\ \text { Economical/Saves Money } & 28.6 \% \\ \text { Air Conditioning/Heating } & 16.5 \% \\ \text { Clean/Safe } & 5.5 \%\end{array}$

For those who said they would not purchase a heat pump the four reasons most often mentioned for their decision were

Too Expensive/High Maint. Costs $32.5 \%$ Lack Information $13.1 \%$

Inefficient/Not Comfortable $\quad 11.5 \%$

Inconvenient/Too much hassle $\quad 8.2 \%$

For those who indicated they were not sure whether or not they would purchase a heat pump the four reasons most often mentioned for their response were 
Lack Information

Don't know why

Too Expensive/High Maint. Costs

other
$61.4 \%$

$19.3 \%$

$10.5 \%$

$8.8 \%$

As would be expected, the reasons given for or against the decision to purchase a heat pump in the hypothetical instance tended to support the mentioned likes and dislikes of heat pumps. The reasons given by the group who were unsure about purchasing a heat pump for their next home were based on a lack of knowledge of heat pump systems. This result suggests that an education problem may still exist even with those who claim to be very or somewhat familiar with heat pump systems.

\subsection{HOMEOWNERS' INTENT TO PURCHASE A HEAT PUMP SYSTEM}

Homeowners were asked how likely they would be to seriously consider purchasing a heat pump for their current residence with in the next two years. Four percent said they were very likely to purchase within the next two years, $8 \%$ said they were somewhat 1 ikely, $21 \%$ said not very 1 ikely, and $65 \%$ said they were not at all likely to purchase a heat pump within the next two years. No significant differences were found across the five segmentation schemes for the homeowners' reported likelihood to purchase a heat pump. No one particular region, life-cycle, attitude set, or fuel user group reported being more likely to purchase a heat pump than the others.

Figures 8.1 and 8.2 present the reported purchase intent of the homeowners by region and primary heating fuel segment. 


\begin{tabular}{|lll|}
\hline W. WA & W.OR \\
& $\begin{array}{l}\text { E. WA, N. ID, W. } \\
\text { MT }\end{array}$ \\
\hline
\end{tabular}

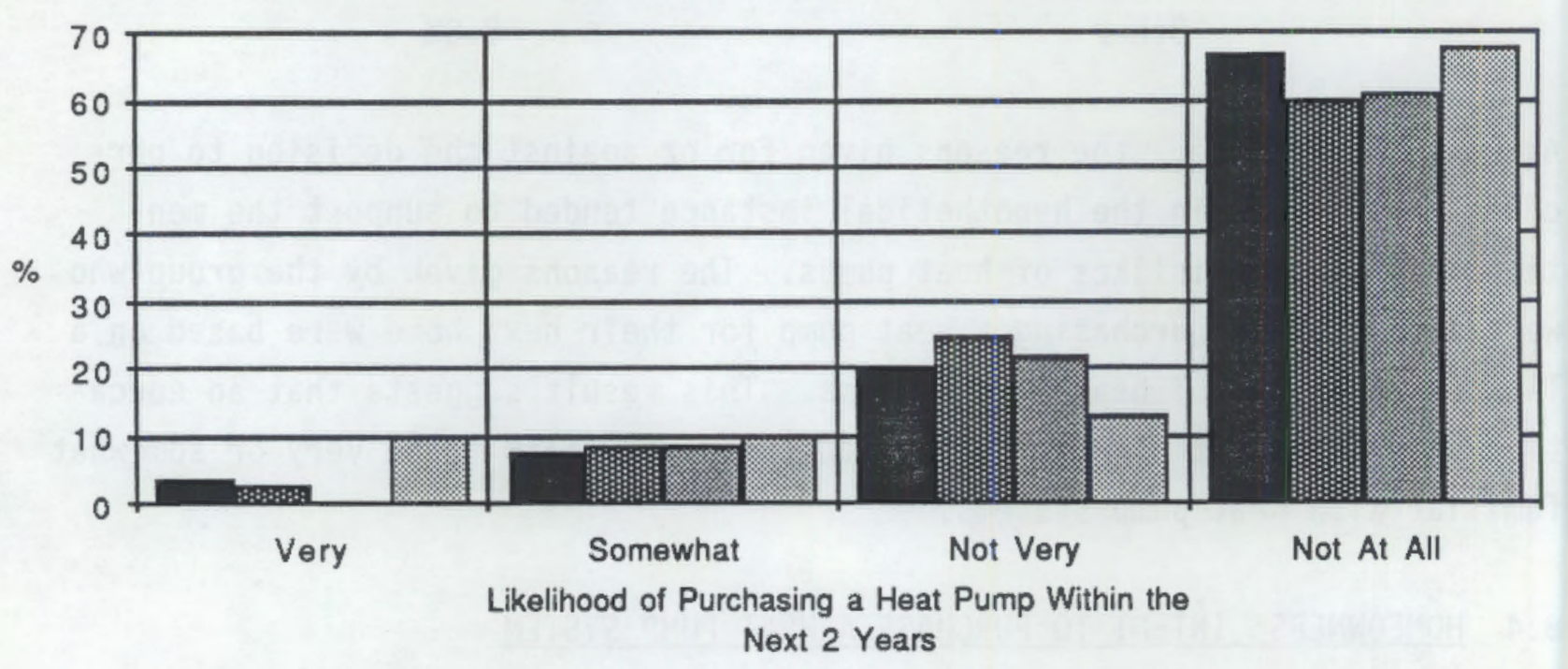

FIGURE 8.1. Intention to Purchase a Heat Pump by Region

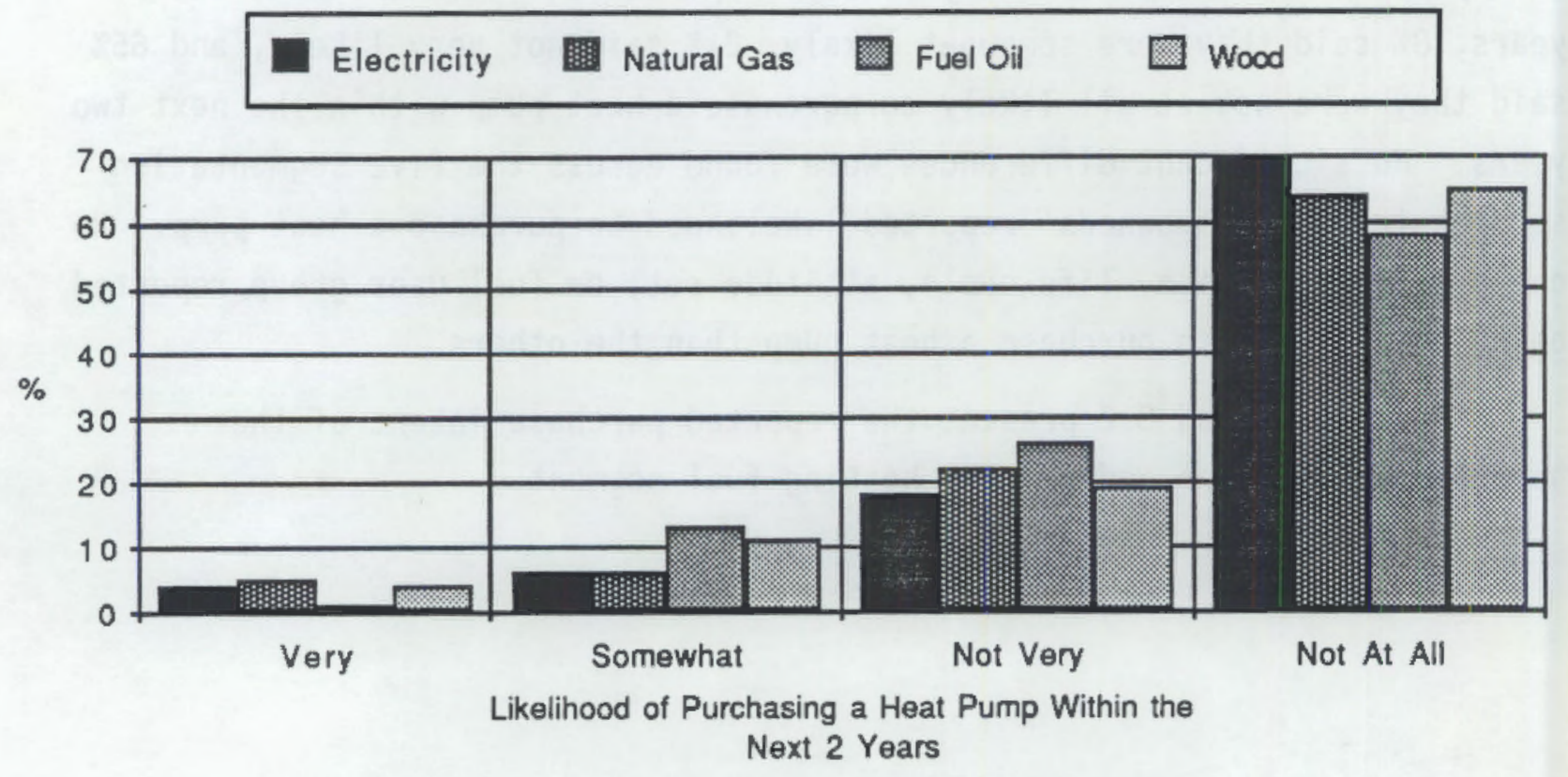

FIGURE 8.2. Intention to Purchase a Heat Pump by Fuel Type 


\subsection{WATER HEATER MARKETING PROGRAMS}

This section is also concerned with a specific piece of residential energy use equipment--water heaters. The focus of this section is not on respondents' perceptions of the equipment, but rather on the present market for water heaters and respondents' awareness of water heater marketing programs.

\subsection{THE REPLACEMENT MARKET FOR RESIDENTIAL WATER HEATERS}

The objective of this section is to describe the water heater market. Since renters are not usually part of the water heater market, only homeowners were asked the age of their water heaters, whether they are presently in the market for a water heater, and if they own or rent their water heater.

Most people who are in the market for a water heater are replacing a broken water heater or are concerned with the age of their present water heater. For the purpose of segmenting the potential water heater market, twelve years is assumed to be the average replacement age of a water heater. Table 9.1 shows the age distribution of the water heaters owned by homeowners in the sample by region, present water heating fuel, and preferred water heating fuel. The information in the table indicates what percentage of homeowners might be replacing their water heaters in the near future.

IABLE 9.1. Age of Water Heater by Region, Present Water Heating Fue 1, and Preferred Water Heating Fuel

\begin{tabular}{|c|c|c|c|c|c|c|c|c|c|}
\hline \multirow{2}{*}{$\begin{array}{l}\text { Age of } \\
\text { Iater } \\
\text { Heator }\end{array}$} & \multirow[b]{2}{*}{$\begin{array}{l}\text { Total } \\
\text { Sanplo }\end{array}$} & & & $\begin{array}{l}\text { Tegion } \\
\text { Testorn Wontama/ } \\
\text { Northern }\end{array}$ & $\begin{array}{l}\text { Southern } \\
\text { Idaho/ }\end{array}$ & \multicolumn{2}{|c|}{ Present Fuel } & \multicolumn{2}{|c|}{ Proferred Fuel } \\
\hline & & $\begin{array}{l}\text { Testern } \\
\text { Iashington }\end{array}$ & $\begin{array}{l}\text { Testarn } \\
\text { Oregon }\end{array}$ & $\begin{array}{c}\text { Idaho/Enstern } \\
\text { Iashington }\end{array}$ & $\begin{array}{l}\text { Esatarn } \\
\text { Orogon } \\
\end{array}$ & $\begin{array}{c}\text { Natural } \\
\text { Gas } \\
\end{array}$ & Eloctricity & $\begin{array}{c}\text { Matural } \\
\text { Gas } \\
\end{array}$ & Electricity \\
\hline $0-4$ & $37 x$ & 398 & $28 x$ & $46 x$ & 34: & $59 x$ & $34 x$ & $46 \pi$ & $34 \pi$ \\
\hline $5-8$ & $20 x$ & $21 x$ & $26 x$ & 15x & 225 & $13 x$ & $21 x$ & $22 \pi$ & $19 x$ \\
\hline $9-12$ & $17 x$ & $15 x$ & $20 x$ & $22 x$ & $19 x$ & $7 x$ & $19 x$ & $12 \pi$ & $18 x$ \\
\hline $13-18$ & $8 x$ & 8x & 8x & 117 & 98 & $2 x$ & $8 x$ & 45 & 97 \\
\hline $17-26$ & 4x & 48 & $7 \pi$ & as & 3: & $2 \pi$ & $5 x$ & $2 x$ & 5x \\
\hline $21+$ & 145 & $14 x$ & $20 x$ & 8x & $13 x$ & $18 x$ & $14 x$ & $15 *$ & $13 x$ \\
\hline
\end{tabular}


Twenty-six percent of the homeowners surveyed reported their water heaters being over 12 years old. These water heaters should soon wear out and the homeowner will enter the water heater market.

A second indication of the size of the water heater replacement market is a self report measure by the respondents. Only $4 \%$ of the homeowners surveyed reported presently being in the market for a new water heater. This percentage is low compared with the $26 \%$ of homeowners that have a water heater over 12 years old. Only $3 \%$ of the surveyed homeowners leased their water heater.

\subsection{WATER HEATER MARXETING PROGRAMS AND INCENTIVES}

The respondents were asked which water heater marketing programs they were aware of and what types of incentives they would prefer for purchasing a specific water heater. Eighty-two percent of the homeowners stated that they were not aware of any programs promoting water heaters.

Those homeowners who reported being aware of at least one marketing program, made only general references to the programs. For example, $35 \%$ of the responses did not mention specific programs or sponsors, but said they thought the local electric or gas utility was sponsoring some type of marketing program. The other responses mentioned specific utilities or retailers as sponsors of programs. The specific utilities or retailers mentioned were Seattle City Light, Cascade Gas Company, Puget Power, Sears, Inner Mountain, and WNG. Also, of those homeowners who had purchased a new water heater within the past year, $86 \%$ stated they had not received an incentive or discount through a program to purchase their water heater.

Since only $18 \%$ of the homeowners stated that they were aware of a water heater marketing program and of these, $35 \%$ did not mention a specific sponsor or program, it is concluded that the awareness of water heating marketing programs is very low.

Homeowners' most preferred incentive for purchasing a water heater was a discount on the price of the water heater. Forty percent of the homeowners stated that price discounts would most influence their decision to purchase a 
specific water heater. Cash rebates would most influence the water heater purchase decision of $21 \%$ of the homeowners and low interest loans would most influence $12 \%$ of the homeowners' decision.

To get an idea of how receptive consumers are to electric utilities providing more than just electricity, all of the respondents were asked their level of agreement with the attitude statements shown in Table 9.2. Consumers appear to think that electric utilities should do more than just provide electricity. The respondents generally agreed that utilities should offer low-interest loans or rebates for energy conservation investments. The respondents expressed some reservation about utilities getting involved with retailing energy use equipment, but there was not an overwhelming number who were against this idea.

IABLE 9.2. Respondents' Level of Agreement With Statements Concerning the Role of Utilities

\begin{tabular}{|c|c|c|c|c|c|}
\hline & $\begin{array}{l}\text { Strongly } \\
\text { Agree }\end{array}$ & Agree & Neutral & Disagree & $\begin{array}{l}\text { Strongly } \\
\text { Disagree }\end{array}$ \\
\hline $\begin{array}{l}\text { I would like to be able to } \\
\text { purchase energy equipment } \\
\text { and appliances through my } \\
\text { electric utility. }\end{array}$ & $4 \%$ & $27^{\circ} 6$ & $22 \%$ & $34 \%$ & $8 \%$ \\
\hline $\begin{array}{l}\text { Utilities should just } \\
\text { concern themselves with } \\
\text { providing electricity and } \\
\text { nothing else. }\end{array}$ & $4 \%$ & $26 \%$ & $13 \%$ & $42 \%$ & $12 \%$ \\
\hline $\begin{array}{l}\text { My utility should offer } \\
\text { low-interest loans or } \\
\text { rebates for energy con- } \\
\text { servation investments. }\end{array}$ & $18 \%$ & $57 \%$ & $12 \%$ & $8 \%$ & $2 \%$ \\
\hline
\end{tabular}





\subsection{REFERENCES}

Brown, F. G., 1970. Principles of Educational and Psychological Testing. Holt, Rhinehart, and Winston, New York, NY.

Elifson, K. W., R. P. Runyon, and A. Haber, 1982. Fundamentals of Social Statistics. Addison-Wesley Publishing Company, Reading, Mass.

Ivey, D. L., J. M. Fang, R. T. Nordi, M. P. Hattrup, and S. A. Shankle. 1987. Household Energy Conservation Attitudes and Behaviors in the Northwest: Tracking Changes Between 1983 and 1985. PNL-5892, Pacific Northwest Laboratory, Richiand, Washington.

Ivey, D. L., M. P. Hattrup, and R. T. Nordi. 1987. 1985 Primary Heating Fuel Use and Switching; Assessment of the Market for Conservation in the Northwest: Phase II. PNL-5881, Pacific Northwest Laboratory, Richland, Washington.

Ivey, D. L., B. M. Bailey, M. P. Hattrup, R. T. Nordi, and S. A. Shankle. 1987. 1985 Consumer Segmentation; Assessment of the Market for Conservation in the Northwest: Phase I1. PNL-6111, Pacific Northwest Laboratory, Richland, Washington.

Ivey, D. L., J. M. Fang, M. P. Hattrup, and R. T. Nordi. 1987. Financing Residential Energy Conservation Investment in the Northwest, 1985. PNL-5905, Pacific Northwest Laboratory, Richland, Washington.

Xalton, G. 1987. Introduction to Survey Sampling. Sage Publications, Inc., Beverly Hills, California.

RMH Research Inc. 1984a. Marketing Environment for Energy Conservation in the Pacific Northwest, prepared for the Pacific Northwest Laboratory by RMH Research, lnc. River Edge, New Jersey.

Schultz, R. W. 1988. Trends in Household Energy Conservation Attitudes and Behaviors in the Northwest: 1983 - 1987. PNL-6572, Pacific Northwest Laboratory, Richland, Washington.

Siegal, S. 1956. Nonparametric Statistics for the Behavioral Sciences. McGraw-Hill, New York, NY. 

APPENDIX A

ANALYTICAL TECHNIQUES 
APPENDIX A

\section{ANALYTICAL TECHNIQUES}

\section{A.1 LIFE-CYCLE SEGMENTATION}

The objective of the life-cycle segmentation is to group households that are most similar on age of household members, sex of household members, and size of household. A clustering technique that assigns cases to clusters based on squared Euclidean distances from cluster centers was used for the analysis. The technique produced nine life-cycle segments.

\begin{tabular}{lcc}
\multicolumn{1}{c}{ Life-cycle Segments } & & $\begin{array}{c}\text { Percent } \\
\text { of Sample }\end{array}$ \\
\cline { 1 - 1 } Early Career Single Adults & & $8.9 \%$ \\
Middle Aged Single Adults & & $4.8 \%$ \\
Elderly Single Adults & $9.1 \%$ \\
Single Parents & & $4.3 \%$ \\
Adults with No Children & & $47.3 \%$ \\
Late Family Stage Households & & $2.3 \%$ \\
Middle Family Stage Households & $18.7 \%$ \\
Large Nuclear Families & & $4.7 \%$
\end{tabular}

\section{A.2 ATTITUDE SEGMENTATIONS}

The respondents are segmented according to their scores on two scales. A scale measures a single construct by sumining the responses of number of items that measure the same construct. For example, a person's Intelligence Quotient (IQ) is estimated according to his/her responses to a set of questions that are supposed to measure the construct of intelligence. The reliability of a scale can be tested for its consistency of measuring the same construct among its scale items.

The internal reliability of a scale is the degree to which the scale items are intercorrelated. Little or no correlation among the scale items indicates that the items may not be measuring the same construct. There are 
a number of tests of internal reliability. Cronbach's alpha is used to test the internal reliability of the scales constructed in this analysis. It can be interpreted as the average correlation between scale items.

Well-developed and accepted measures of personality, interest, and values generally have a reliability of 0.80 (Brown 1970 p. 78). A considerably lower reliability can be expected for the initial attempts at constructing new attitude scales.

The smart shopper segmentation scheme is based on the respondents' score on a scale constructed from attitude statements. Possible scores on the scale range from one to ten. Respondents scoring a seven or above are categorized as smart shoppers.

The respondents were asked to rate their level of agreenent with the following three attitude statements:

Q.120 I usually go to several stores to find the lowest prices for the important items I buy.

$\begin{aligned} & \text { Strongly } \\ & \text { Disagree }\end{aligned}$
1 $\frac{\text { Disagree }}{2} \quad \frac{\text { Neutral }}{3} \quad \frac{\text { Agree }}{4} \quad \frac{\begin{array}{c}\text { Strongly } \\ \text { Agree }\end{array}}{5}$

Q.121 I consult Consumer Reports or similar publications before making major purchases.

Strongly

Disagree

1

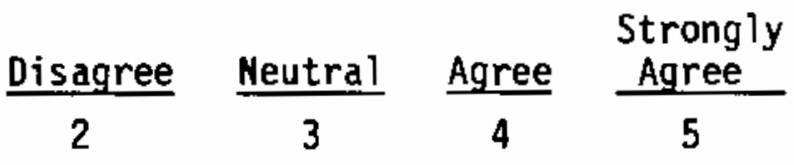

Q.12B The cost of something I am buying is more important to me than its other qualities.

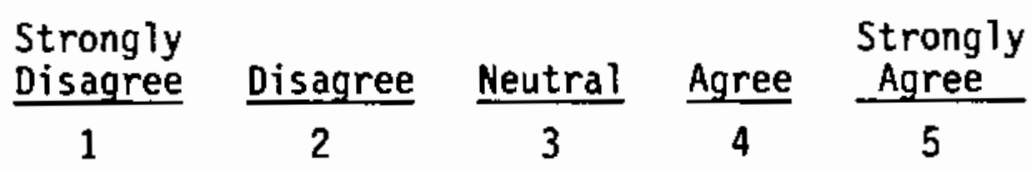

Responses were summed and the internal reliability among the three statements was tested using Cronbach's alpha. The internal reliability of the threeitem scale was an alpha of 0.2421 . An examination of the inter-item correlation matrix revealed a low correlation between $Q .128$ and the other two 
statements. The removal of $Q .128$ from the scale increased the internal reliability to an alpha of 0.4177 . Q.128 is measuring the cost facet of a product purchase in relation to other product qualities. Having cost be the sole determinate of a purchase decision is probably not being a "smart shopper." The respondents were segmented according to their score on the two item scale.

The innovator segmentation scheme is based on a scale constructed from attitude statements and product purchase behavior. The possible scores on the scale range from one to twenty. Respondents scoring a thirteen or above are categorized as innovators.

The innovator scale was constructed from the following questions:

Q.122 1 like to try out new products before other people do.

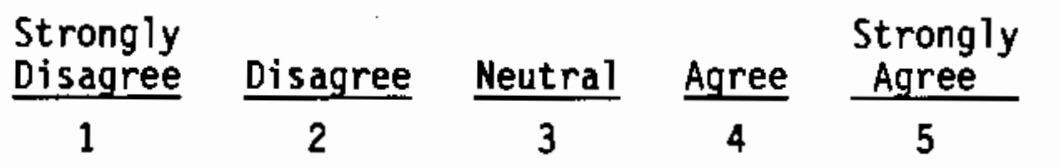

Q.132 Other people often ask my opinion on new products.

Strongly

Disagree Disagree Neutral Agree Agree $\begin{array}{llllll}1 & 2 & 3 & 4 & 5\end{array}$

Q.134 About how many years ago did you purchase a VCR?

Q.135 Would you say you are likely to purchase a VCR ...

1 Within a year?

2 Within one to two years?

3 Not likely to purchase a VCR at all?

Q.137 About how many years ago did you purchase a CD player?

Q.138 Would you say you are likely to purchase a CD player

1 Within a year?

2 Within one to two years?

3 Not likely to purchase a $C D$ at all? 
To convert these questions into a single innovator scale, the product purchase behavior responses were recoded into a five-point scale based on the frequency distributions for the specific questions. Those respondents purchasing a VCR over five years ago were rated a five; those purchasing a VCR between three and five years ago were rated a four; those purchasing a VCR one to two years ago were rated a three; those reporting they were likely to purchase a VCR were rated a two; and those saying they would not purchase a VCR were rated a one.

Those respondents purchasing a CD player over a year ago were rated a five; those purchasing a CD player within the past year were rated a four; those reporting they were likely to purchase a $C D$ player within the next year were rated a three; those reporting they were likely to purchase a $C D$ player within one to two years were rated a two; and those saying they would not purchase a CD player were rated a one.

The respondents' recoded responses were summed with their responses to the two attitude statements. The internal reliability of the four-item scale was an alpha of 0.4091 . No improvement in the internal reliability was obtained by deleting scale items.

\section{A.3 ANALYSIS OF VARIANCE TECHNIQUES}

Friedman's two-way analysis of variance by ranks is an appropriate test for the analysis of variance between matched samples when the data are in at least an ordinal scale. It is a nonparametric test that approximates a chi square distribution (Siegel 1956 p. 168). Friedman's analysis of variance is used to test the hypothes is that consumers have different perceptions of the various heating fuels.

The respondents rated eight heating fuel attributes for each of four separate heating fuels. The respondents were asked to rate how well the attribute described the fuel in question on a four-point scale ranging from $\dot{c}$ poor description (1) to a very good description (4). The respondents' ratings of each attribute for each fuel and the summation of ratings across all attributes for each fuel were tested for statistically significant differences. 
The Kruska]-Wallis one-way analys is of variance by ranks is used to test whether $k$ independent samples are from different populations. The KruskalWallis analysis of variance technique requires at least ordinal level data and approximates a chi square distribution. "Sampie values almost invariably differ somewhat, and the question is whether the differences among the samples signify genuine population differences or whether they represent merely chance variations such as are to be expected among several random samples from the same population" (Siegel 1956 p.184).

The Kruskal-Wallis one-way analysis of variance by ranks is used to test for differences between perceptions of the importance of the fuel attributes across the segmentation schemes. It is al so used to test for differences in a number of variables across the segmentation schemes. In testing for differences across segmentation schemes, the Kruskal-Wallis test is used whenever ordinal data are involved (e.g., fuel switcher by "innovator"). For segmentation schemes that involve only categorical data (e.g., fuel switcher by region), a different test is used.

\section{A.4 MEASURES OF STATISTICAL SIGNIFICANCE FOR CATEGORICAL DATA \\ The chi square distribution is used to test for the significance of the associations between the variables. Associations that are not significant at least at the 0.05 level are not reported.}



APPENDIX B

\section{SELECTED DEMOGRAPHICS}


APPENDIX B

SELECTED DEMOGRAPHICS

Q1 HOME OWNERSHIP

VALUE LABEL

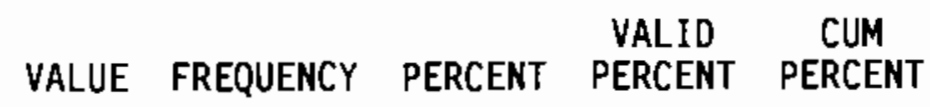

$\begin{array}{lrrrrr}\text { OWN } & 1 & 610 & 59.6 & 59.6 & 59.6 \\ \text { RENT } & 2 & 413 & 40.4 & 40.4 & 100.0 \\ & & & -1023 & 100.0 & 100.0\end{array}$

Q3

PRESENT HEATING FUEL

VALUE LABEL

VALUE FREQUENCY PERCENT PERCENT PERCENT

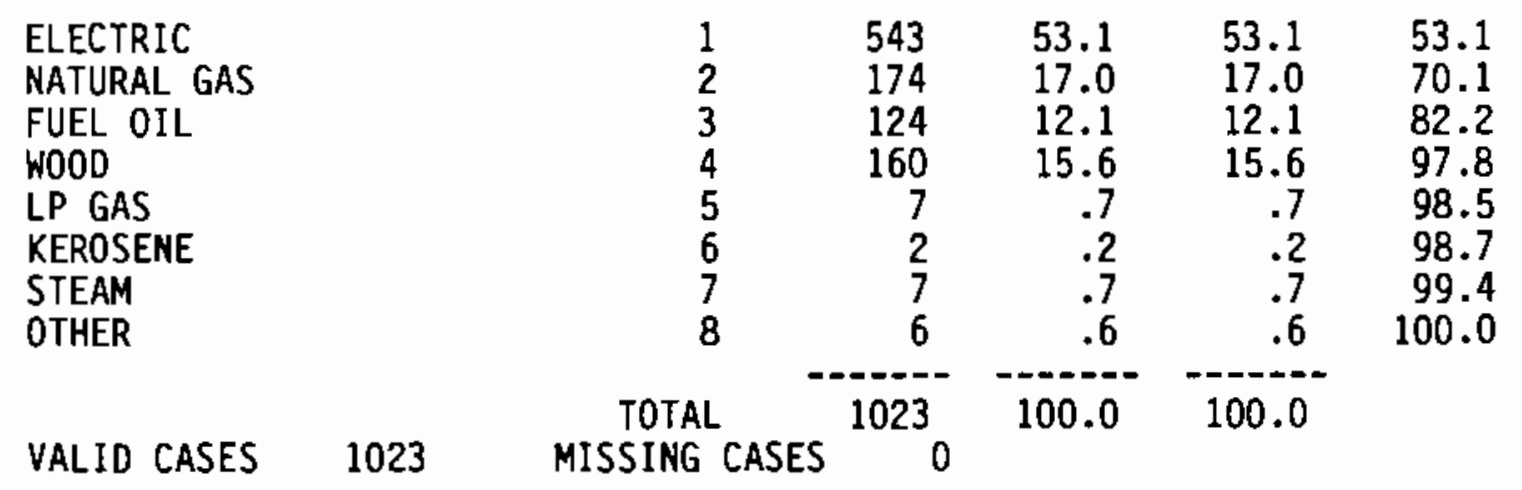

Q4 ELEC. HEATING SYS.

VALUE LABEL

VALUE FREQUENCY PERCENT PERCENT PERCENT

FORCED AIR

BASEBOARD

HEAT PUMP

SPACE HEATER

WALL HEATER

OTHER

CEILING HEAT

VALID CASES

1171

$2 \quad 249$

$3 \quad 23$

$4 \quad 10$

$5 \quad 49$

$6 \quad 9$

$7 \quad 32$

480

$\begin{array}{cc}\text { TOTAL } & 1023 \\ \text { MISSING CASES } & 480\end{array}$

\begin{tabular}{rrr}
16.7 & 31.5 & 31.5 \\
24.3 & 45.9 & 77.3 \\
2.2 & 4.2 & 81.6 \\
1.0 & 1.8 & 83.4 \\
4.8 & 9.0 & 92.4 \\
.9 & 1.7 & 94.1 \\
3.1 & 5.9 & 100.0 \\
46.9 & MISSING & \\
\hline 100.0 & 100.0 &
\end{tabular}




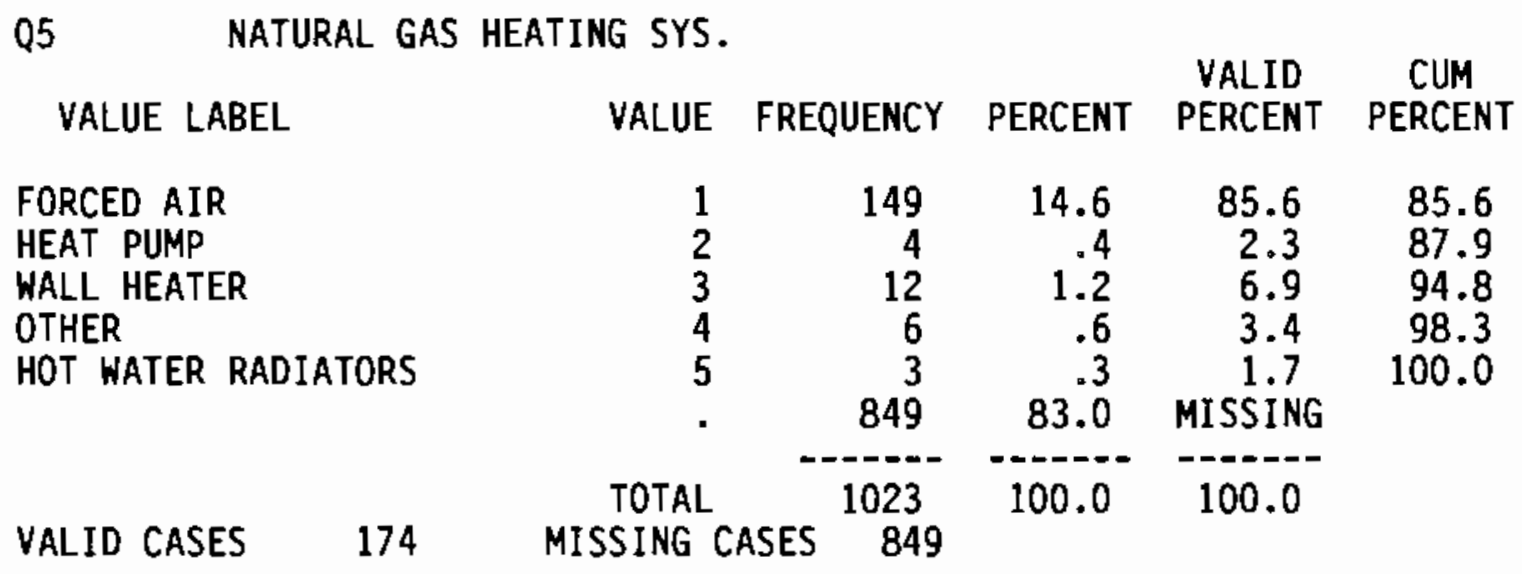

\begin{tabular}{|c|c|c|c|c|c|c|}
\hline & & VALUE & FREQUENCY & PERCENT & $\begin{array}{l}\text { VALID } \\
\text { PERCENT }\end{array}$ & $\begin{array}{c}\text { CUM } \\
\text { PERCENT }\end{array}$ \\
\hline $\begin{array}{l}\text { STOVE } \\
\text { INSERT } \\
\text { FIREPLACE } \\
\text { FURNACE } \\
\text { OTHER }\end{array}$ & & $\begin{array}{r}1 \\
2 \\
3 \\
4 \\
5\end{array}$ & $\begin{array}{r}127 \\
20 \\
5 \\
7 \\
1 \\
863\end{array}$ & $\begin{array}{r}12.4 \\
2.0 \\
.5 \\
.7 \\
.1 \\
84.4\end{array}$ & $\begin{array}{c}79.4 \\
12.5 \\
3.1 \\
4.4 \\
\text { MISSING }\end{array}$ & $\begin{array}{c}79.4 \\
91.9 \\
95.0 \\
99.4 \\
100.0\end{array}$ \\
\hline VALID CASES & 160 & $\begin{array}{l}\text { TOTAL } \\
\text { ISSSING }\end{array}$ & ASES $\begin{array}{c}1023 \\
863\end{array}$ & 100.0 & 100.0 & \\
\hline
\end{tabular}

\begin{tabular}{|c|c|c|c|c|c|c|}
\hline VALUE LABEL & & VALUE & FREQUENCY & PERCENT & $\begin{array}{l}\text { VALID } \\
\text { PERCENT }\end{array}$ & $\begin{array}{c}\text { CUM } \\
\text { PERCENT }\end{array}$ \\
\hline $\begin{array}{l}\text { FORCED AIR } \\
\text { WALL HEATER } \\
\text { OTHER }\end{array}$ & & $\begin{array}{l}1 \\
2 \\
3 \\
.\end{array}$ & $\begin{array}{r}111 \\
1 \\
12 \\
899\end{array}$ & $\begin{array}{r}10.9 \\
.1 \\
1.2 \\
87.9\end{array}$ & $\begin{array}{r}89.5 \\
.8 \\
9.7 \\
\text { MISSING }\end{array}$ & $\begin{array}{r}89.5 \\
90.3 \\
100.0\end{array}$ \\
\hline VALID CASES & 124 & $\begin{array}{l}\text { TOTAL } \\
\text { MISSING }\end{array}$ & ASES $\begin{array}{c}1023 \\
\text { A }\end{array}$ & 100.0 & 100.0 & \\
\hline
\end{tabular}

Q10 PRESENCE OF BACKUP SYS.

VALUE LABEL

YES

NO

VALID CASES 1023

VALUE FREQUENCY PERCENT PERCENT $\begin{gathered}\text { VALID } \\ \text { PERCENT }\end{gathered}$ 
Q11 BACKUP HEATING FUEL

VALUE LABEL

ELECTRIC

NATURAL GAS

FUEL OIL

WOOD

LP GAS

KEROSENE

HEAT PUMP

OTHER

FIREPLACE

VALID CASES
VALUE FREQUENCY PERCENT PERCENT $\begin{array}{cc}\text { VALID } \\ \text { PERCENT }\end{array}$

$\begin{array}{rrrrr}1 & 142 & 13.9 & 35.9 & 35.9 \\ 2 & 18 & 1.8 & 4.5 & 40.4 \\ 3 & 15 & 1.5 & 3.8 & 44.2 \\ 4 & 198 & 19.4 & 50.0 & 94.2 \\ 5 & 3 & .3 & .8 & 94.9 \\ 6 & 3 & .3 & .8 & 95.7 \\ 7 & 5 & .5 & 1.3 & 97.0 \\ 8 & 5 & .5 & 1.3 & 98.2 \\ 9 & 7 & .7 & 1.8 & 100.0 \\ . & 627 & 61.3 & \text { MISSING } & \end{array}$

TOTAL $1023 \quad 100.0 \quad 100.0$
Q12

VALUE LABEL

FORCED AIR

BASEBOARD

SPACE HEATER

WALL HEATER

OTHER

CEILING HEAT

MISSING CASES 627

\section{BKUP ELEC. SYS.}

VALUE FREQUENCY PERCENT PERCENT PERCENT

$\begin{array}{rrrrr}1 & 44 & 4.3 & 31.0 & 31.0 \\ 2 & 51 & 5.0 & 35.9 & 66.9 \\ 4 & 20 & 2.0 & 14.1 & 81.0 \\ 5 & 17 & 1.7 & 12.0 & 93.0 \\ 6 & 6 & .6 & 4.2 & 97.2 \\ 7 & 4 & .4 & 2.8 & 100.0\end{array}$

VALID CASES $142 \quad$ MISSING CASES 881

$881 \quad 86.1$ MISSING

$100.0 \quad 100.0$

\section{Q13 BKUP GAS SYS.}

VALUE LABEL

FORCED AIR

WALL HEATER

FIREPLACE

VALID CASES
VALID CUM

VALUE FREQUENCY PERCENT PERCENT PERCENT

\begin{tabular}{rrrrr}
1 & 15 & 1.5 & 83.3 & 83.3 \\
3 & 1 & .1 & 5.6 & 88.9 \\
5 & 2 & .2 & 11.1 & 100.0 \\
- & 1005 & 98.2 & MISSING & \\
\hline & 1023 & 100.0 & 100.0 &
\end{tabular}


Q14 BKUP WOOD SYS.

VALUE LABEL

VALUE FREQUENCY PERCENT $\begin{gathered}\text { VALID } \\ \text { PERCENT }\end{gathered}$ PERCENT

STOVE
INSERT
FIREPLACE
FURNACE
OTHER

VALID CASES
$4^{2}$
82

43

71

1

1

825

$\begin{array}{cc}\text { TOTAL } & 1023 \\ \text { MISSING CASES } & 825\end{array}$

8.0

21.7

$6.9 \quad 35.9$

.5

$\begin{array}{lll}.1 & .5 & 100.0\end{array}$

80.6 MISSING

Q15

VALUE LABEL

FORCED AIR

WALL HEATER

OTHER

VALID CASES
BKUP OIL SYS.

VALUE FREQUENCY PERCENT PERCENT $\begin{gathered}\text { VALID } \\ \text { PERCENT }\end{gathered}$

\begin{tabular}{|c|c|c|c|c|c|c|}
\hline VALUE LABEL & & VALUE & FREQUENCY & PERCENT & $\begin{array}{l}\text { VALID } \\
\text { PERCENT }\end{array}$ & $\begin{array}{c}\text { CUM } \\
\text { PERCENT }\end{array}$ \\
\hline $\begin{array}{l}\text { ELECTRICITY } \\
\text { NATURAL GAS } \\
\text { WOOD } \\
\text { FUEL OIL } \\
\text { LP GAS } \\
\text { KEROSENE } \\
\text { HEAT PUMP } \\
\text { SOLAR } \\
\text { OTHER }\end{array}$ & & $\begin{array}{l}1 \\
2 \\
3 \\
4 \\
5 \\
6 \\
7 \\
8 \\
9\end{array}$ & $\begin{array}{r}362 \\
364 \\
143 \\
50 \\
19 \\
50 \\
17 \\
15 \\
3\end{array}$ & $\begin{array}{r}35.4 \\
35.6 \\
14.0 \\
4.9 \\
1.9 \\
4.9 \\
1.7 \\
1.5 \\
.3\end{array}$ & $\begin{array}{r}35.4 \\
35.6 \\
14.0 \\
4.9 \\
1.9 \\
4.9 \\
1.7 \\
1.5 \\
.3\end{array}$ & $\begin{array}{r}35.4 \\
71.0 \\
84.9 \\
89.8 \\
91.7 \\
96.6 \\
98.2 \\
99.7 \\
100.0\end{array}$ \\
\hline & 1023 & $\begin{array}{l}\text { TOTAL } \\
\text { SSING }\end{array}$ & ASES ${ }^{1023}$ & 100.0 & 100.0 & \\
\hline
\end{tabular}


VALUE LABEL

SNGL FAM DWELL DU TRI QUADPLEX

MULTI UNITS COMPLX

MOBILE HOME

BOAT

DON'T KNOW
VALUE FREQUENCY PERCENT $\begin{gathered}\text { VALID } \\ \text { PERCENT }\end{gathered}$ PERCENT

$\begin{array}{lllll}1 & 684 & 66.9 & 66.9 & 66.9\end{array}$

$\begin{array}{llll}94 & 9.2 & 9.2 & 76.1\end{array}$

$\begin{array}{llll}173 & 16.9 & 16.9 & 93.1\end{array}$

$\begin{array}{llll}66 & 6.5 & 6.5 & 99.5\end{array}$

$\begin{array}{rrrr}3 & .3 & .3 & 99.8\end{array}$

$\begin{array}{lll}.2 & .2 & 100.0\end{array}$
VALID CASES 1022

VALUE LABEL

PRE-SCHOOL

PRIMARY SCHOOL

SECONDARY SCHOOL

COLLEGE AGE

EARLY CAREER

MIDDLE AGE

ELDERLY
VALUE FREQUENCY PERCENT PERCENT PERCENT \begin{tabular}{l} 
VALID CASES \\
012 \\
\hline Q150
\end{tabular}

VALUE LABEL

PRE-SCHOOL

PRIMARY SCHOOL

SECONDARY SCHOOL

COLLEGE AGE

EARLY CAREER

MIDDLE AGE

ELDERLY

VALID CASES 236
VALUE FREQUENCY PERCENT PERCENT PERCENT

$\begin{array}{llll}\text { TOTAL } & 1023 & 100.0 & 100.0\end{array}$

211

$\begin{array}{rrrr}6 & .6 & .7 & .7 \\ 6 & .6 & .7 & 1.5 \\ 9 & .9 & 1.1 & 2.6 \\ 20 & 2.0 & 2.5 & 5.0 \\ 294 & 28.7 & 36.2 & 41.3 \\ 364 & 35.6 & 44.8 & 86.1 \\ 113 & 11.0 & 13.9 & 100.0\end{array}$




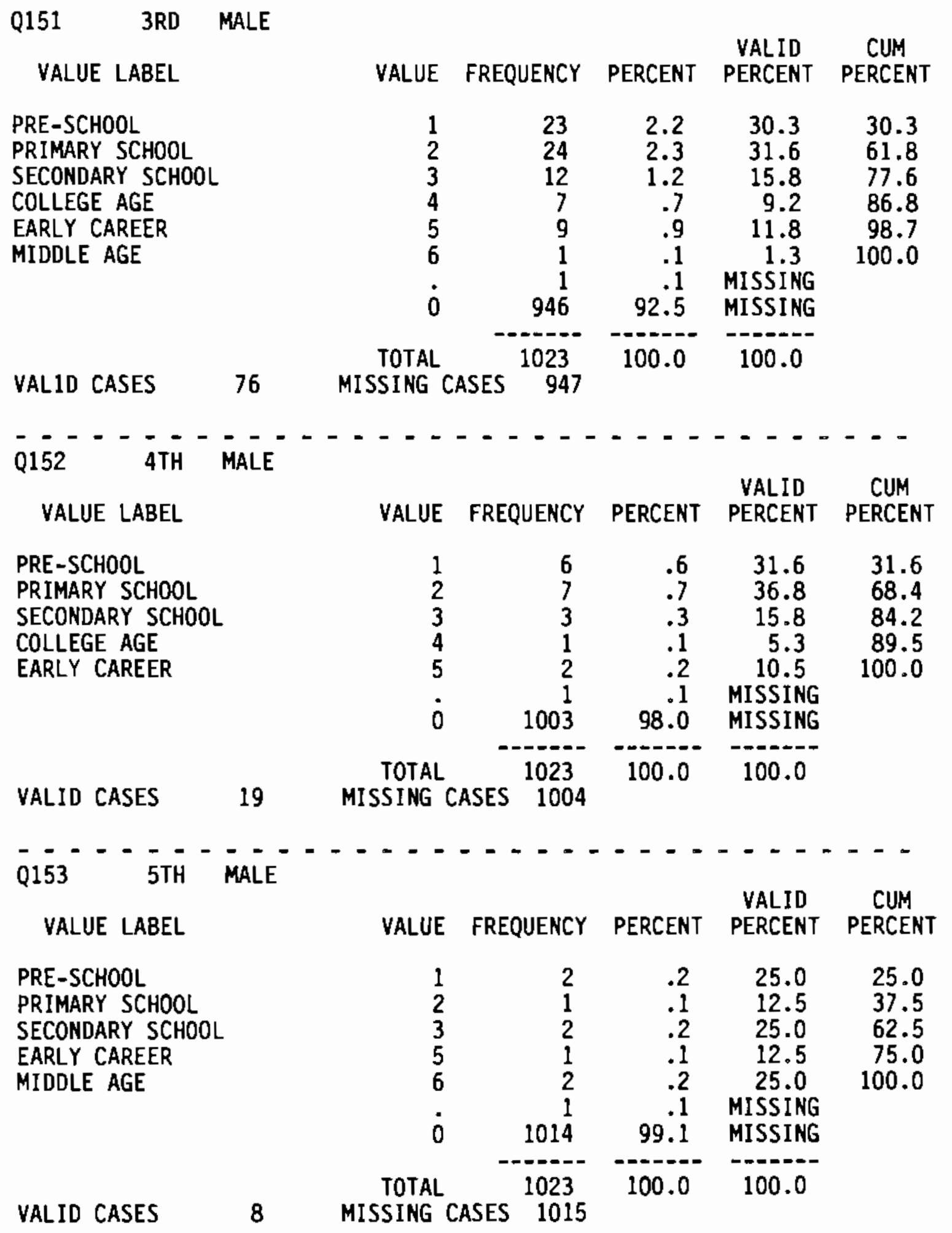


Q154 FEMALE

VALUE LABEL

$\begin{array}{llcc} & & \text { VALID } & \text { CUM } \\ \text { VALUE FREQUENCY } & \text { PERCENT } & \text { PERCENT } & \text { PERCENT }\end{array}$

PRE-SCHOOL

PRIMARY SCHOOL

SECONDARY SCHOOL

COLLEGE AGE

EARLY CAREER

MIDDLE AGE

ELDERLY

VALID CASES $877 \quad$ MISSING CASES 146

VALID CASES $877 \quad$ MISSING CASES 146

1

$2 \quad .2$

2.2

$36 \quad 3.5$

$288 \quad 28.2$

38.1

390

156

7

15.2

.2
.3
.2
.5
.2
.1
.2
.1
.2

$\begin{array}{ll}.2 & .2 \\ .3 & .6\end{array}$

.8

4.14 .9

$\begin{array}{lll}32.8 & 37.7\end{array}$

44.5

82.2

$17.8 \quad 100.0$

MISSING

MISSING

$\begin{array}{llll}\text { TOTAL } & 1023 & 100.0 & 100.0\end{array}$

Q155 2ND FEMALE

VALUE LABEL

$\begin{array}{llcc}\text { VALUE } & \text { FREQUENCY } & \text { PERCENT } & \text { CUL } \\ \text { PERCENT } & \text { PERCENT }\end{array}$

PRE-SCHOOL

PRIMARY SCHOOL

SECONDARY SCHOOL

COLLEGE AGE

EARLY CAREER

MIDDLE AGE

ELDERLY

VALID CASES 228

$\begin{array}{lllll}1 & 40 & 3.9 & 17.5 & 17.5\end{array}$

$\begin{array}{lllll}2 & 51 & 5.0 & 22.4 & 39.9\end{array}$

$\begin{array}{lllll}3 & 43 & 4.2 & 18.9 & 58.8\end{array}$

$\begin{array}{lllll}4 & 34 & 3.3 & 14.9 & 73.7\end{array}$

$\begin{array}{lllll}5 & 42 & 4.1 & 18.4 & 92.1\end{array}$

$\begin{array}{lllll}6 & 16 & 1.6 & 7.0 & 99.1\end{array}$
MISSING CASES 795
TOTAL

7

2

794

100.0

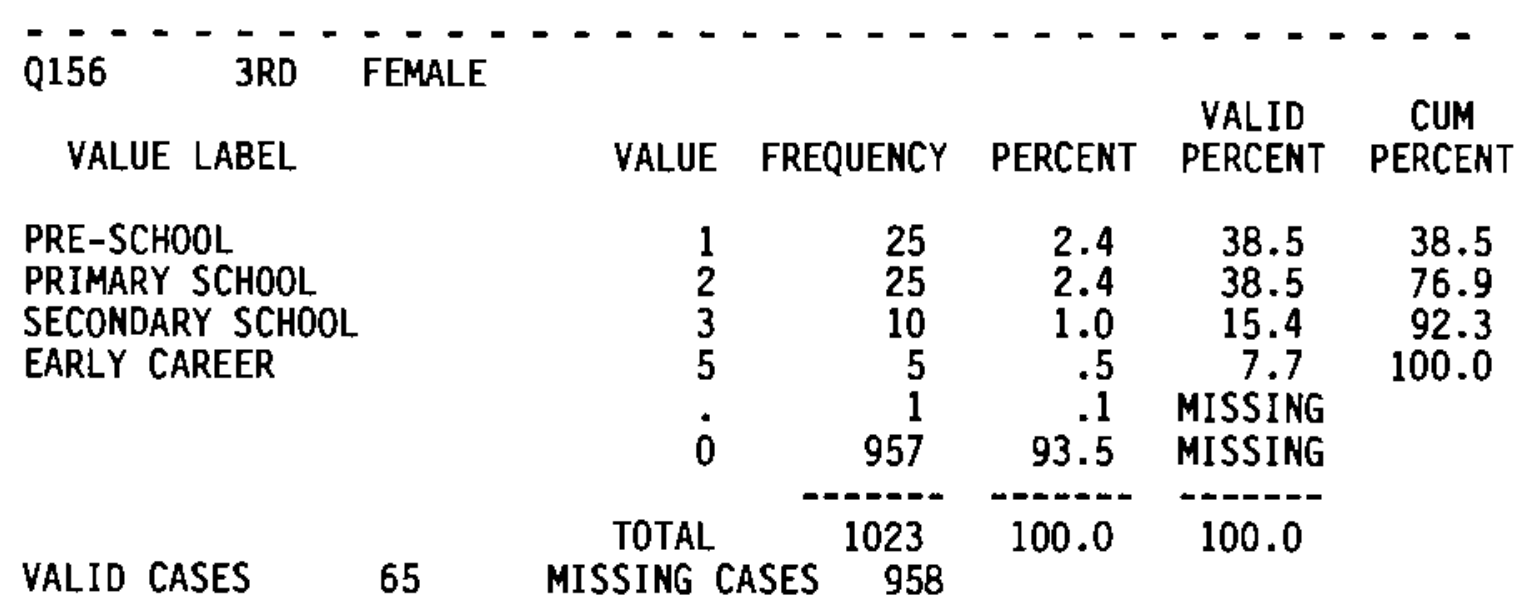

VALID CASES

MISSING CASES 958 
Q157 4TH FEMALE

VALUE LABEL VALUE FREQUENCY PERCENT PERCENT PERCENT

PRE-SCHOOL PRIMARY SCHOOL SECONDARY SCHOOL

VALID CASES

\begin{tabular}{rrrrr}
1 & 8 & .8 & 61.5 & 61.5 \\
2 & 4 & .4 & 30.8 & 92.3 \\
3 & 1 & .1 & 7.7 & 100.0 \\
0 & 1 & .1 & MISSING & \\
0 & 1009 & 98.6 & MISSING & \\
\hdashline-10 & -100.0 & 100.0 &
\end{tabular}

\begin{tabular}{|c|c|c|c|c|c|c|}
\hline VALUE LABEL & & VALUE & FREQUENCY & PERCENT & $\begin{array}{c}\text { VALID } \\
\text { PERCENT }\end{array}$ & $\begin{array}{c}\text { CUM } \\
\text { PERCENT }\end{array}$ \\
\hline $\begin{array}{l}\text { PRE-SCHOOL } \\
\text { PRIMARY SCHOOL }\end{array}$ & & $\begin{array}{l}1 \\
2 \\
0\end{array}$ & $\begin{array}{r}2 \\
2 \\
1 \\
1018\end{array}$ & $\begin{array}{r}.2 \\
.2 \\
.1 \\
99.5\end{array}$ & $\begin{array}{r}50.0 \\
50.0 \\
\text { MISSING } \\
\text { MISSING }\end{array}$ & $\begin{array}{r}50.0 \\
100.0\end{array}$ \\
\hline VALID CASES & 4 & $\begin{array}{l}\text { TOTAL } \\
\text { MISSING C }\end{array}$ & ASES $\begin{array}{c}1023 \\
1019\end{array}$ & 100.0 & 100.0 & \\
\hline Q159 RESPC & 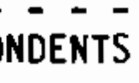 & & & & & \\
\hline VALUE LABEL & & VALUE & FREQUENCY & PERCENT & PERCENT & PERCENT \\
\hline $\begin{array}{l}\text { PRF/MGR } \\
\text { CLERC/SALE/SER } \\
\text { CRFT/OPERT/FRM } \\
\text { HOMEMAKER } \\
\text { RET IRED } \\
\text { UNEMPL. } \\
\text { MILITARY } \\
\text { SELF EMP } \\
\text { STUDENT }\end{array}$ & & $\begin{array}{r}1 \\
3 \\
5 \\
9 \\
10 \\
11 \\
12 \\
13 \\
14 \\
15 \\
99 \\
.\end{array}$ & $\begin{array}{r}266 \\
189 \\
98 \\
129 \\
204 \\
26 \\
6 \\
29 \\
49 \\
1 \\
16 \\
10\end{array}$ & $\begin{array}{r}26.0 \\
18.5 \\
9.6 \\
12.6 \\
19.9 \\
2.5 \\
.6 \\
2.8 \\
4.8 \\
.1 \\
1.6 \\
1.0\end{array}$ & $\begin{array}{r}26.3 \\
18.7 \\
9.7 \\
12.7 \\
20.1 \\
2.6 \\
.6 \\
2.9 \\
4.8 \\
.1 \\
1.6 \\
\text { MISSING }\end{array}$ & $\begin{array}{r}26.3 \\
44.9 \\
54.6 \\
67.3 \\
87.5 \\
90.0 \\
90.6 \\
93.5 \\
98.3 \\
98.4 \\
100.0\end{array}$ \\
\hline VALID CASES & 1013 & $\begin{array}{l}\text { TOTAL } \\
\text { MISSING C }\end{array}$ & CASES $\begin{array}{c}1023 \\
10\end{array}$ & 100.0 & 100.0 & \\
\hline
\end{tabular}




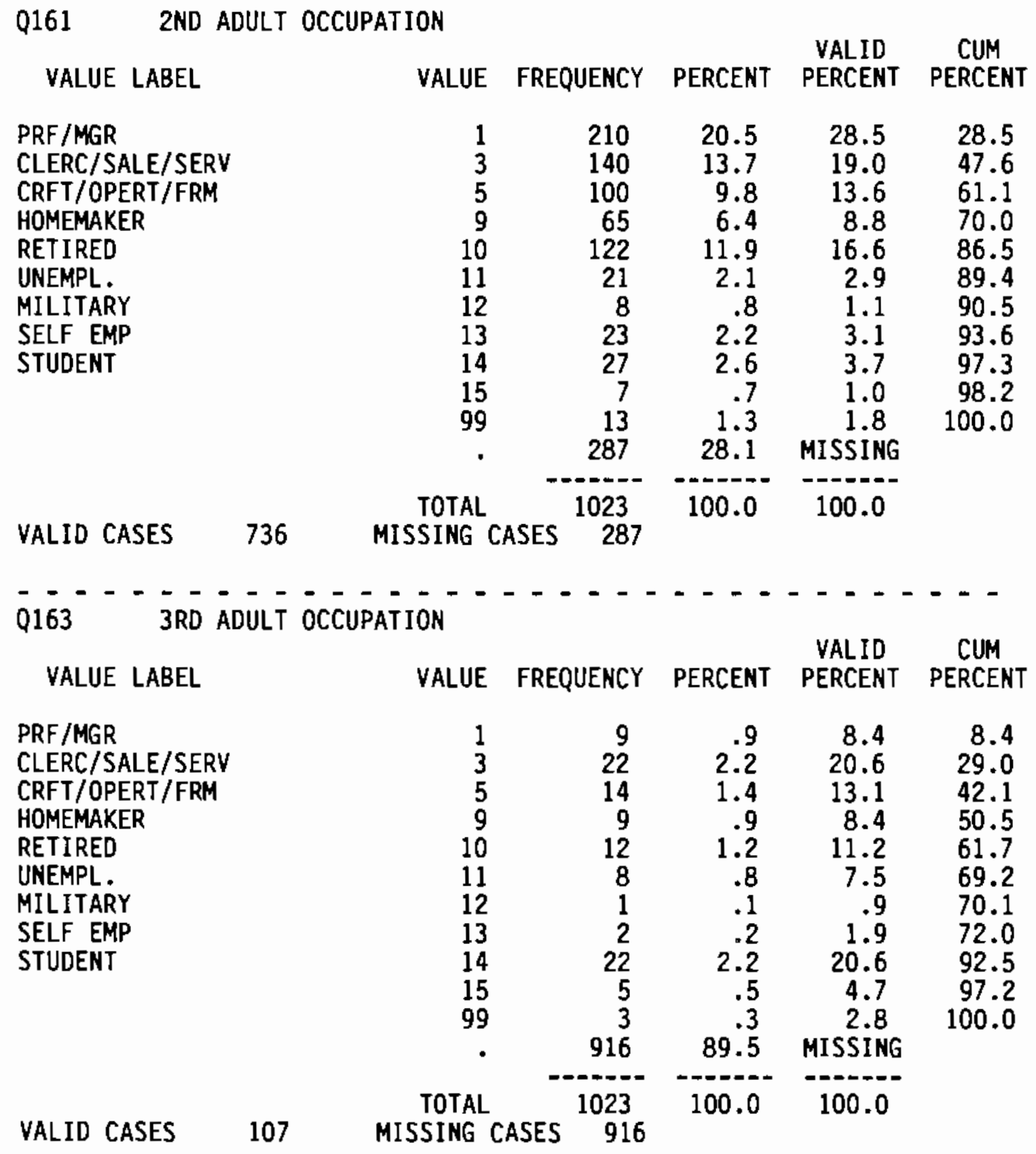


Q167 RESPONDENTS EDUCATION

VALUE LABEL

VALUE FREQUENCY PERCENT PERCENT $\begin{gathered}\text { CUM } \\ \text { PERCENT }\end{gathered}$

NO SCHL

SOME ELEM

COMPL. ELEM.

SOME H.S.

COMPL. H.S.

SOME COLLEGE

COMPL. COLL.

SOME GRAD

COMPL. GRAD

VALUE FREQUEN

COMPL. GRAD

VALID CASES $1022 \quad \begin{gathered}\text { TO } \\ \text { Q168 }\end{gathered}$

VALUE LABEL

VALUE FREQUENCY PERCENT PERCENT PERCENT

NO SCHL

SOME ELEM

COMPL. ELEM.

SOME H.S.

COMPL. H.S.

SOME COLLEGE

COMPL. COLL.

SOME GRAD

COMPL. GRAD

VALID CASES

737

$\begin{array}{rrrrr}0 & 2 & .2 & .3 & .3 \\ 1 & 2 & .2 & .3 & .5 \\ 2 & 8 & .8 & 1.1 & 1.6 \\ 3 & 50 & 4.9 & 6.8 & 8.4 \\ 4 & 236 & 23.1 & 32.0 & 40.4 \\ 6 & 223 & 21.8 & 30.3 & 70.7 \\ 7 & 114 & 11.1 & 15.5 & 86.2 \\ 8 & 30 & 2.9 & 4.1 & 90.2 \\ 9 & 37 & 3.6 & 5.0 & 95.3 \\ 77 & 19 & 1.9 & 2.6 & 97.8 \\ 99 & 16 & 1.6 & 2.2 & 100.0 \\ . & 286 & 28.0 & \text { MISSING } & \\ \text { TOTAL } & -1023 & -100.0 & 100.0 & \\ \text { MISSING CASES } & 286 & & & \end{array}$


Q169 3RD ADULT EDUCATION

VALUE LABEL

SOME ELEM

SOME H.S.

COMPL. H.S.

SOME COLLEGE

COMPL. COLL.

SOME GRAD

COMPL. GRAD
VALUE FREQUENCY PERCENT PALRCENT PERCENT

$\begin{array}{lllll}1 & 2 & .2 & 1.9 & 1.9\end{array}$

$\begin{array}{lllll}3 & 7 & .7 & 6.5 & 8.4\end{array}$

$\begin{array}{lllll}4 & 48 & 4.7 & 44.9 & 53.3\end{array}$

$\begin{array}{lllll}6 & 22 & 2.2 & 20.6 & 73.8\end{array}$

$\begin{array}{rrrrr}7 & 7 & .7 & 6.5 & 80.4\end{array}$

$\begin{array}{lllll}8 & 3 & .3 & 2.8 & 83.2\end{array}$

$\begin{array}{lllll}9 & 2 & .2 & 1.9 & 85.0\end{array}$

$\begin{array}{lllll}77 & 10 & 1.0 & 9.3 & 94.4\end{array}$

$\begin{array}{lllrr}99 & 6 & .6 & 5.6 & 100.0\end{array}$

$\begin{array}{lllll}\text { VALID CASES } & \text { TOTAL } & 1023 & 100.0 & 100.0\end{array}$

$916 \quad 89.5$ MISSING

Q171 1NCOME

VALUE LABEL

$<15 \mathrm{~K}$

$15-29 \mathrm{~K}$

$30-44 \mathrm{~K}$

$45-59 \mathrm{~K}$

$60-74 \mathrm{~K}$

$75 \mathrm{~K}+$

VALID CASES 1022 MISSING CASES 1

VALUE LABEL

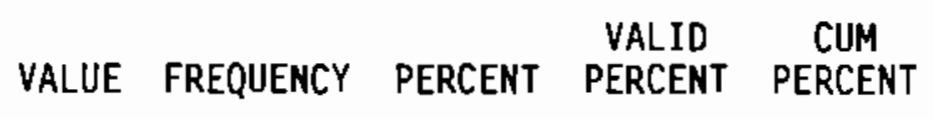

$\begin{array}{rrrrr}1 & 229 & 22.4 & 22.4 & 22.4 \\ 2 & 293 & 28.6 & 28.7 & 51.1 \\ 3 & 197 & 19.3 & 19.3 & 70.4 \\ 4 & 103 & 10.1 & 10.1 & 80.4 \\ 5 & 44 & 4.3 & 4.3 & 84.7 \\ 6 & 22 & 2.2 & 2.2 & 86.9 \\ 9 & 134 & 13.1 & 13.1 & 100.0 \\ . & 1 & .1 & \text { MISSING } & \end{array}$

REGION

VALID CASES 1018

VALUE FREQUENCY PERCENT PERCENT $\begin{gathered}\text { CUM } \\ \text { PERCENT }\end{gathered}$

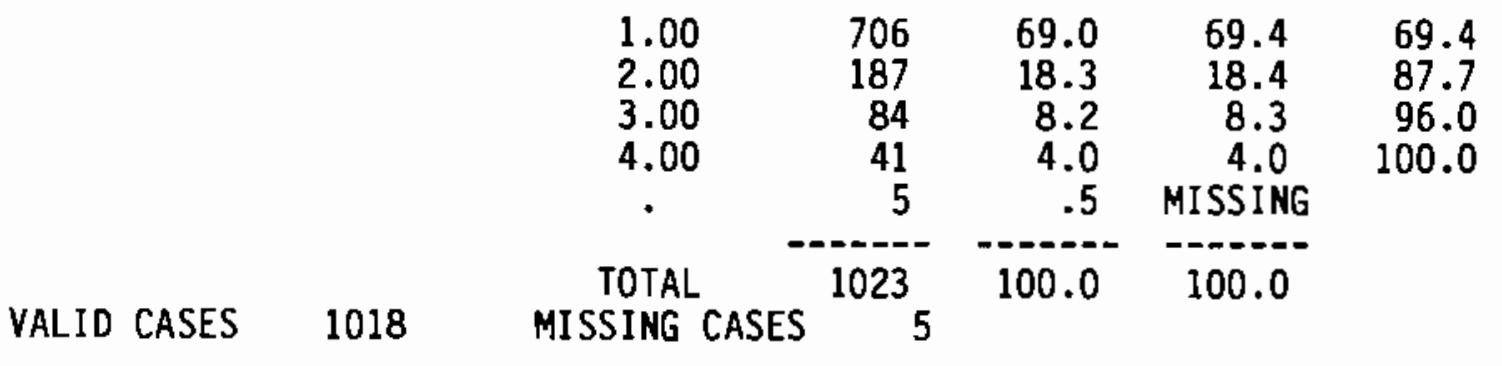


INNOVATE

VALUE LABEL

VALUE FREQUENCY PERCENT $\begin{array}{ccc}\text { VALID } & \text { CUM } \\ \text { PERCENT } & \text { PERCENT }\end{array}$

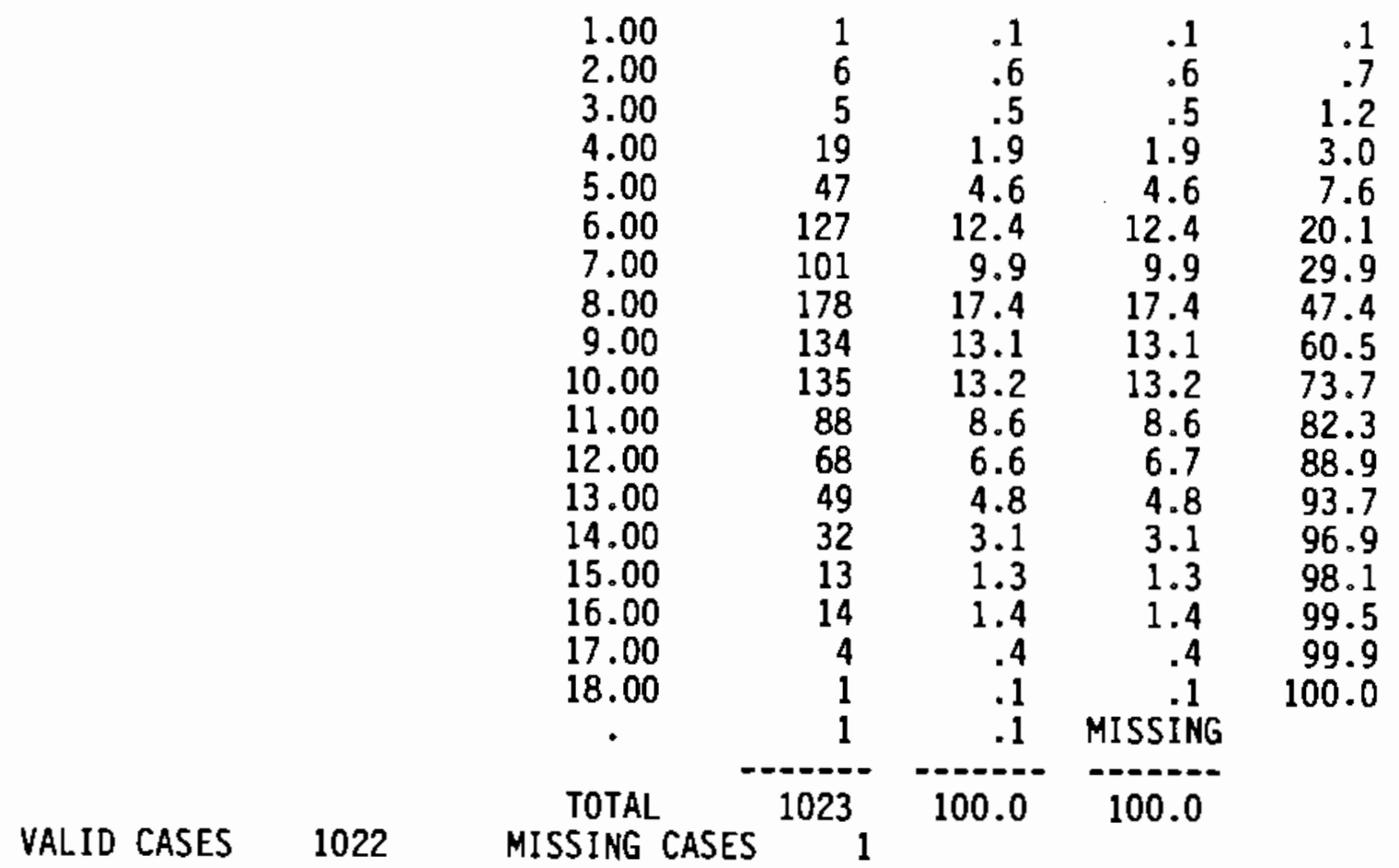

SHOPPER

VALUE LABEL

VALUE FREQUENCY PERCENT PERCENT PERCENT

VALID CASES $1020 \quad$ TOTAL MISSING CASES

$\begin{array}{rrrrr}2.00 & 13 & 1.3 & 1.3 & 1.3 \\ 3.00 & 14 & 1.4 & 1.4 & 2.6 \\ 4.00 & 103 & 10.1 & 10.1 & 12.7 \\ 5.00 & 66 & 6.5 & 6.5 & 19.2 \\ 6.00 & 237 & 23.2 & 23.2 & 42.5 \\ 7.00 & 104 & 10.2 & 10.2 & 52.6 \\ 8.00 & 304 & 29.7 & 29.8 & 82.5 \\ 9.00 & 110 & 10.8 & 10.8 & 93.2 \\ 10.00 & 69 & 6.7 & 6.8 & 100.0 \\ . & 3 & .3 & \text { MISSING } & \\ \text { TOTAL } & -1023 & 100.0 & 100.0 & \\ \text { MISSING CASES } & 3 & & & \end{array}$




\section{CLUSMEM}

\begin{tabular}{lrrrrr}
\multicolumn{1}{c}{ VALUE LABEL } & VALUE & FREQUENCY & PERCENT & $\begin{array}{r}\text { VALID } \\
\text { PERCENT }\end{array}$ & \multicolumn{1}{c}{ CUM } \\
PERCENT
\end{tabular}


.

. 
APPENDIX C

PHASE III QUESTIONNAIRE 


\section{APPENDIX C}

\section{PHASE II I QUESTIONNAIRE}

Hello, this is with Market Trends, a firm that conducts public opinion surveys. We're doing a survey here in the Pacific Northwest and I'd like to ask you a few questions. May I please speak with the head of the household mostly responsible or equally responsible for decisions regarding your home's heating system?

(DO NOT VOLUNTEER, BUT IF ASKED SAY .... 'This questionnaire is sponsored by Battelle Pacific Northwest Laboratories. You are not required to respond, but your cooperation would really be appreciated.')

S.1 What is the name of your electric utility?

Q.1 Do you own or rent your residence?

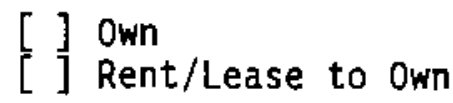

Q.2 About how many years have you lived in your current residence? YEARS

Q.3 What fuel do you use most for heating your home? (ONE MENTION)

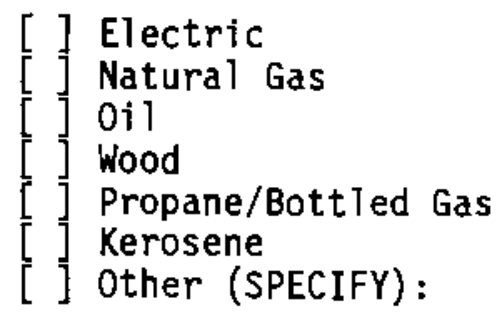

Q.4 (IF ELECTRIC) Would that be a ..... (READ)

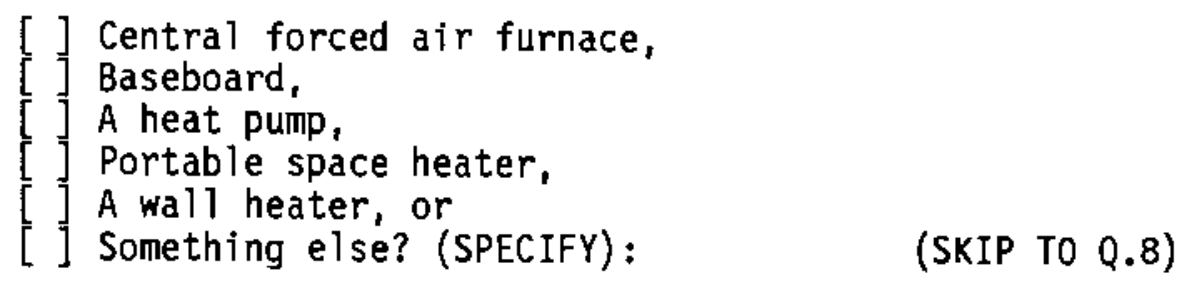


Q.5 (IF NATURAL GAS) Would that be a..... (READ)

[ ] Central forced air furnace,
[ ] A gas heat pump,
[ ] A wall heater, or
[ ] Something else (SPECIFY):

(SKIP TO Q.8)

Q.6 (IF WOOD) Would that be a..... (READ)

[ ] Wood burning stove,
[ ] A fireplace insert,
[ A fireplace alone,
[ ] Wood furnace, or
[ ] Something el se? (SPECIFY)

Q.7 (IF FUEL OIL) Would that be a..... (READ)

[ ] Central forced air furnace,
[ ] A wall heater, or
[ ] Something else? (SPECIFY):

Q.8 For what reasons do you heat primarily with with another heating fue1? (PROBE/CLARIFY)

rather than

(IF RESPONSE IN Q.8 WAS 'IT WAS PRESENT IN THE HOUSE WHEN WE BOUGHT IT', DO NOT ASK Q.9, ENTER A 2, AND CONTINUE)

Q.9 Did you or someone in your household decide on the primary heating system currently used in your home, or was it already installed when you moved into your home?

[ ] Resident was the decision maker

[ ] System was already installed or someone else made the decision

Q.10 Do you have a secondary, or backup heating system?

[ ] $\begin{aligned} & \text { Yes } \\ & \text { No }\end{aligned}$ (IF NO, SKIP TO Q.16)

Q.11 What fuel does this system use?

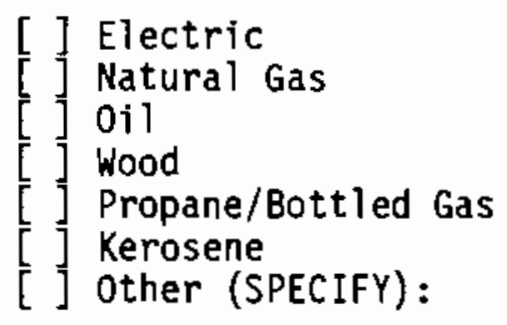


Q.12 (IF ELECTRIC) Would that be a..... (READ)

[ ] Central forced air furnace,
[ ] Baseboard,
[ ] A heat pump,
[ ] Portable space heater,
[ ] A wall heater, or
[ ] Something else? (SPECIFY):

(SKIP TO Q.16)

Q.13 (IF NATURAL GAS) Would that be a..... (READ)

[ ] Centra] forced air furnace,

[ I A gas heat pump,

[ ] A wall heater, or

[ ] Something else (SPECIFY):

(SKIP TO Q.16)

Q.14 (IF WOOD) Would that be a...... (READ)

[ ] Wood burning stove,

A fireplace insert,

A fireplace alone,

Wood furnace, or

Something else? (SPECIFY) (SKIP TO Q.16)

Q.15 (IF FUEL OIL) would that be a...... (READ)

[ ] Central forced air furnace,

A wall heater, or

Something else? (SPECIFY):

Q.16 Assuming you were about to move into a new home and could choose any fuel for heating, what would you choose? (READ LIST)

[ ] Electricity,
[ ] Natural Gas,
[ Wood,
[ ] Fuel 0il, or
[ ] Other (SPECIFY):
[ (DON'T READ) No Preference

Q.17 For what reasons would you prefer this?

(IF IN HOME LESS THAN 2 YRS, GO TO Q.21)

(IF RENT, GO TO Q.24)

Q.18 You mentioned your primary heating fuel is case two years ago, or not? - Was this the

[ ] Yes (IF YES, GO TO Q.21)
[ ] No 
Q.19 What fuel did you rely on then?

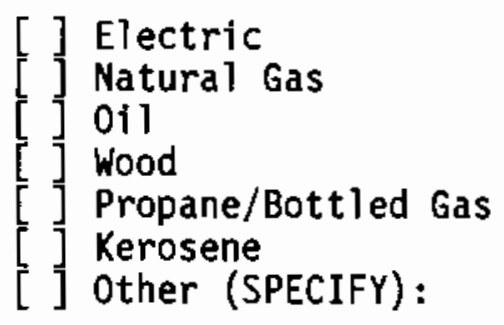

Q.20 For what reasons did you change from to ?

Q.21 Will you be considering changing your primary heating fuel in the coming two years, or not?

[] Yes
[] Maybe/Unsure
[]$_{\text {No }}$

(IF NO, GO TO Q.24)

Q.22 To what fuel would you likely switch?

[ ] Electric
[ ] Natural Gas
$[$ Oil
$[$ ] Wood
$[$ ] Propane/Bottled Gas
[ ] Kerosene
[ ] Other (SPECIFY):

Q.23 For what reasons would you be switching from ? to

Q.24 To your knowledge, is natural gas available in your neighborhood as a heating fuel? (We are referring to gas that would be piped in from a gas main, not bottled gas.)

[ ] Yes
[ ] No
[ ] Unsure

Q.25 To the best of your knowledge, what is the MOST expensive home heating fuel? (READ)

[] Electricity
$[$ Natura] Gas
[] Wood
[] OiT
[] (DON'T READ) Unsure 
Q.26 And what is the LEAST expensive home heating fuel? (READ)

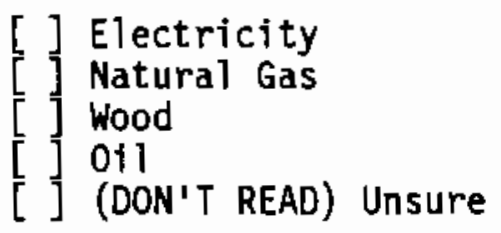

Q.27 Thinking five years from now, which do you think will be the most expensive for home heating .... (READ)

[ ] Electricity
[ ] Natural Gas
[ Wood
[ ] Oil
[ ] (DON'T READ) Unsure

Q.28 When you think of the cost of electricity, are you more likely to think of it in terms of.... (READ)

[ ] Your electric bill

[ ] Rate per kilowatt hour

[ ] (DON'T READ) Don't Know/Unsure (IF 8ILL OR UNSURE, GO TO Q.30)

Q.29 To your knowledge, what is the price per kilowatt hour you pay for electricity in your home? (ENTER 777 FOR DON'T XNOW)

PRICE PER XILOWATT HOUR

Q.30 Is your electric bill... (READ)

[ ] Monthly

(DON'T READ) Don't Know/Unsure

Q.31-38 I'm going to read to you a list of characteristics of heating fuels. Imagine that you are in the market for a new heating system for your home, how important to you would it be that your preferred heating fuel have the characteristics mentioned. Would you say it is not at all important, not very important, somewhat important, or very important that a heating fuel..... (READ)

Q.31 be Economical?

[ ] Not at all important
[ ] Not very important
[ ] Somewhat important
[ ] Very important
[ ] DON'T XNOW 
Q.32 be Efficient?

[ ] Not at all important
[ Not very important
[ ] Somewhat important
[ ] Very important
[ ] DON'T KNOW

Q.33 be Dependable?

[ ] Not at all important
[ ] Not very important
[ ] Somewhat important
[ ] Very important
[ DON'T KNOW

Q.34 be Convenient to Use?

[ ] Not at all important
[ Not very important
[ Somewhat important
[ ] Very important
[ ] DON'T kNOW

Q.35 be Safe?

[ ] Not at all important

Not very important

Somewhat important

Very important

DON'T KNOW

Q.36 be Non-polluting?

[ ] Not at all important

Not very important

Somewhat important

Very important

DON'T KNOW

Q.37 Provide comfortable heating (warm the house evenly, easy temperature control)?

[ ] Not at all important
[ ] Not very important
[ Somewhat important
[ ] Very important
[ ] DON'T KNOW 
Q.38 Not have an offensive odor?

[ ] Not at all important
[ ] Not very important
[ ] Somewhat important
[ ] Very important
[ ] DON'T KNOW

Q.39-0.70 I' $\mathrm{m}$ going to read a list of words and phrases which could be used to describe different heating fuels. I would like you to tell me how well each word or phrase describes gas, electricity, oil and wood. On a scale from 1 to 4,1 meaning it does not describe the fuel at all and 4 meaning it is a very good descriptor of the fuel, please tell me how well the word or phrase describes the fuet.

Q.39-Q.46 How well does the word (phrase) describe NATURAL GAS?

\section{Q.39 Low-cost}

$\begin{array}{ll}{[\text { ] Poor Description }} & 1 \\ {[} & 2 \\ {[} & 3 \\ {[} & \\ \text { [ ] Very Good Descrjption } 4 \\ \text { [ DON'T KNOW/NO EXPERIENCE }\end{array}$

Q.40 Unreliable

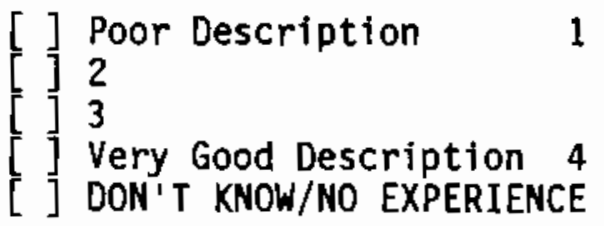

Q.41 Safe

[ ] Poor Description 1
$[$ ] 2
$[$ [ 3
[] Very Good Description 4
[ ] DON'T KNOW/NO EXPERIENCE

Q.42 Polluting

[ ] Poor Description 1

[] 2

[] 3

[ Very Good Description 4

1 


\section{Q.43 Comfortable}

$[$ [] Poor Description
$[$ [ 2
$[$ [ 3
$[$ [ Very Good Description 4
[ ] DON'T KNOW/NO EXPERIENCE

Q.44 Inefficient

[ ] Poor Description
$[$ [ 2
$[$ [ 3
$[$ ] Very Good Description 4
[ ] DON'T KNOW/NO EXPERIENCE

Q.45 Hassie-free operation

$[$ ] Poor Description
$[$ [ 2
$[$ [ 3
$[$ ] Very Good Description 4
$\left[\right.$ [ ${ }_{\text {DON'T KNOW/NO EXPERIENCE }}$

Q.46 Has an unpleasant odor

[] Poor Description
$\left[{ }^{2}\right.$
[] 3
[] Very Good Description 4
$[$ DON'T KNOW/NO EXPERIENCE

Q.47-Q.54 How well does the word (phrase) describe ELECTRICITY?

\section{Q.47 Low-cost}

$[$ ] Poor Oescription
$\left[\begin{array}{l}2 \\ {[} \\ {[}\end{array}\right]$ Very Good Description 4
$[$ ] DON'T KNOW/NO EXPERIENCE

Q.48 Unreliable

[ ] Poor Description
[] 2
[] 3
[] Very GoOd Description 4
[ ] DON'T KNOW/NO EXPERIENCE 
Q.49 Safe

$\left[\begin{array}{l}\text { Poor Description } \\ {[] 2}\end{array}\right.$
$\left[\begin{array}{l}3 \\ {[}\end{array}\right]$ Very Good Description 4
[ ] DON'T KNOW/NO EXPERIENCE

Q.50 Poltuting

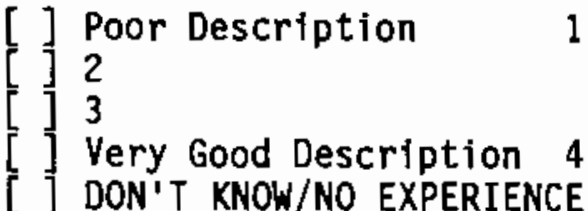

Q.51 Comfortable

$[$ [ Poor Description
$[$ ] 2
$[$ ] 3
$[$ [ Very Good Description 4
$[$ ] DON'T KNOW/NO EXPERIENCE

Q.52 Inefficient

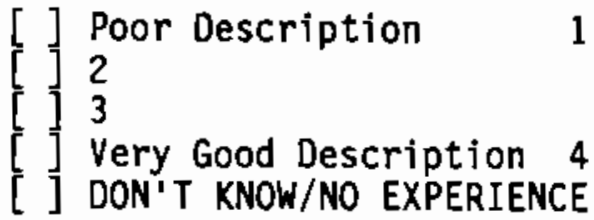

Q.53 Hassle-free operation

$[$ ] Poor Description
$[$ ] 2
[] 3
[] Very Good Description 4
$[$ ] DON'T KNOW/NO EXPERIENCE

Q.54 Has an unpleasant odor

$\left\{\begin{array}{l}\text { [ Poor Description } \\ {\left[\begin{array}{l}2 \\ 3 \\ 3\end{array}\right] \text { Very Good Description } 4} \\ \text { [ ] DON'T KNOW/NO EXPERIENCE }\end{array}\right.$ 
Q.55-Q.62 How well does the word (phrase) describe WOOD?

Q.55 Low-cost

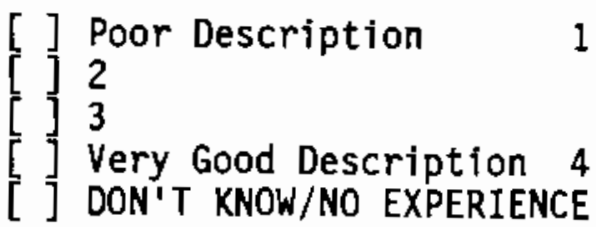

Q.56 Unreliable

[ ] Poor Description
$[$ ] 2
[ ] 3
[ ] Very Good Description 4
[] DON'T KNOW/NO EXPERIENCE

Q.57 Safe

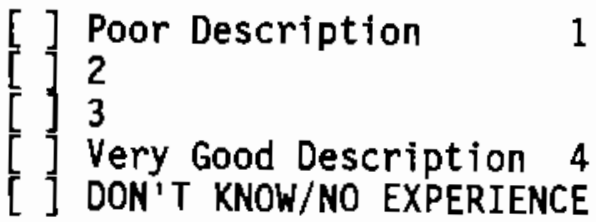

Q.58 Polluting

[ ] Poor Description
$[$ [ 2
$[$ [ 3
[ ] Very Good Description 4
[ ] DON'T KNOW/NO EXPERIENCE

Q.59 Comfortable

[ ] Poor Description
$[$ [ 2
$[$ [ 3
[ Very Good Description 4
[ ] DON'T KNOW/NO EXPERIENCE

Q.60 Inefficient

$\begin{array}{ll}{[\text { ] }} & \text { Poor Description } \\ \text { [ ] } 2 \\ \text { [ ] } 3 \\ \text { [ ] Very Good Description } 4 \\ \text { [ ] DON'T KNOW/NO EXPERIENCE }\end{array}$ 
Q.61 Hassle-free operation

[ ] Poor Description 1
$[$ ] 2
$[$ [ 3
[ ] Very GOOd Description 4
[ ] DON'T KNOW/NO EXPERIENCE

Q.62 Has an unpleasant odor

[ ] Poor Description
[ $] 2$
[ ] Very Good Description 4
[ ] DON'T KNOW/NO EXPERIENCE

Q.63-Q.70 How well does the word (phrase)____describe OIL?

Q.63 Low-cost

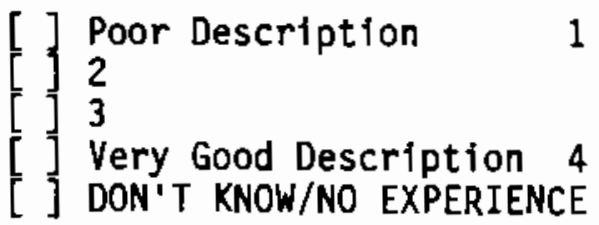

Q.64 Unreliable

$[$ ] Poor Description
$\left[\begin{array}{l}2 \\ {[}\end{array}\right]$
$\left[\begin{array}{l}3 \\ {[}\end{array}\right]$ Very Good DescriptIon 4
$[$ DON'T KNOW/NO EXPERIENCE

Q.65 Safe

[ ] Poor Description 1

[ ] 2

3

[ Very Good Description 4

[ ] DON'T KNOW/NO EXPERIENCE

Q.66 Polluting

[ ] Poor Description
$[$ ] 2
$[$ [ 3
$[$ [ Very Good Description 4
[ ] DON'T KNOW/NO EXPERIENCE 


\section{Q.67 Comfortable}

$\begin{array}{ll}{[\text { ] }} & \text { Poor Description } \\ {[]} & 1 \\ {[} & 3 \\ {[} & \\ {[} & \text { Very Good Description } 4 \\ \text { [ ] DON'T KNOW/NO EXPERIENCE }\end{array}$

Q.68 Inefficient

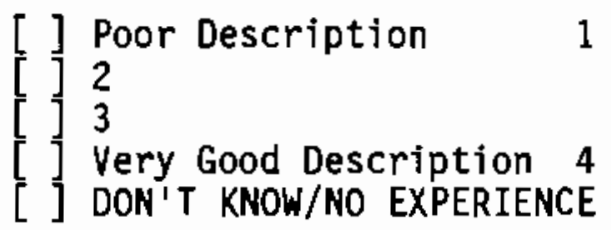

Q.69 Hassle-free operation

$\begin{array}{ll}{[\text { ] }} & \text { Poor Description } \\ {[]} & 1 \\ {[} & 3 \\ {[} & \\ {[} & \text { Very Good Description } 4 \\ \text { [ ] DON'T KNOW/NO EXPERIENCE }\end{array}$

Q.70 Has an unpleasant odor

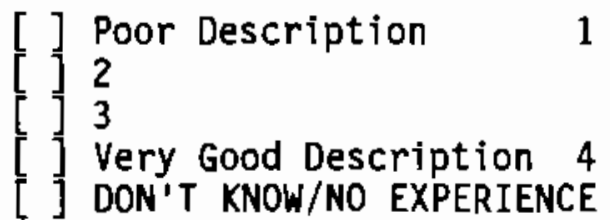

(IF DO NOT HEAT WITH WOOD, GO TO Q.80) (IF RENT, GO TO Q.95)

Q.71 About how many years ago was your wood heating equipment installed? (ENTER 77 FOR DON'T KNOW)

YEARS

Q.72 Under what circumstances would you use less wood for home heating and rely more on ? 
Q.73 About how many cords of wood do you expect to burn for your home this heating season? (ENTER 77 FOR DON'T KNOW/UNSURE AND 99 FOR REFUSED)

DESCRIPTION OF A CORD OF WOOD: A cord is stacked wood in dimensions of $4 \times 4 \times 8$ feet or 128 cubic feet. Or roughly a standard size pickup load stacked 3 feet high.

CORDS

Q.74 WouTd you say that is more, less or about the same amount as you burned in last year's heating season ('86-'87)?

$\left[\begin{array}{ll}\text { [ } & \text { More } \\ \text { [ ] } & \text { Less } \\ \text { Same }\end{array}\right.$

(IF LESS, GO TO Q.76)

(IF SAME, GO TO 0.77 )

Q.75 For what reasons did you burn more wood last season? (GO TO Q.77)

Q.76 For what reasons did you burn less wood last season?

Q.77 of the amount this heating season, about what percent did you gather yourself? (ENTER 777 FOR DON'T KNOW)

PERCENT

Q.78 About what percent did you purchase and have delivered to your home? (ENTER 777 FOR DON'T KNOW)

PERCENT

Q.79 What was the price per cord that you paid for your wood? (ENTER 777 FOR DON'T KNOW)

PRICE PER CORD

(GO TO Q.84)

Q.80 Do you have a wood stove, fireplace insert, or wood furnace in your residence?

$\left[\begin{array}{ll}\text { Yes } \\ \text { No }\end{array}\right.$ (IF NO, GO TO Q.82) 
Q.81 For what reasons do you not use your wood stove or insert for heating? (PROBE/CLARIFY)

Q.82 Have you ever considered purchasing a wood stove or fireplace insert for use in your current residence, or not?

[] Yes No (IF NO, GO TO Q.84)

Q.83 For what reasons did you decide not to obtain a wood stove or insert for heating? (PROBE/CLARIFY)

Q.84 Did you receive a rebate, discount, or other incentive to install heating equipment in your home?

[ ] Y Nos

Q.85 For what equipment was/were the incentive(s)?

Q.86 What was the amount of the incentive, rebate, or discount?

Q.87 Would you say you are.... (READ)

[ ] Very familiar,

[ ] Somewhat familiar,

[ Not very familiar, or (IF NOT FAMILIAR, GO TO Q.93)

[ ] Not at all familiar with heat pump systems?

Q.88 Have you heard of a water or ground coupled heat pump?

[] Yes
[ ] No
[ ] Unsure

Q.89 What do you like about a heat pump system?

Q.90 What don't you like about a heat pump system? 
Q.91 If you were to purchase another heating system for your next home, would you purchase a heat pump?

[ ] Yes
[ ] No
[ Unsure

Q.92 Why is that? (PROBE FOR CUSTOMER SATISFACTION)

Q.93 Were you aware a heat pump provides air conditioning as well as home heating?

$\left[\begin{array}{l}\text { Yes } \\ \text { [ }] \text { No } \\ \text { [ Unsure }\end{array}\right.$

Q.94 In the coming two years, how likely will you be to seriously consider purchasing a heat pump for your current residence? Would you say..... (READ)

[ ] Very likely,
[ ] Somewhat likely,
[ ] Not very likely, or
[ ] Not at all likely?
[ ] (DON'T READ) Don't Know

Q.95-97 I am going to read a list of appliances. Please tell me if you have the appliance and what type of fuel it uses.

Q.95 (READ IF NECESSARY: Please tell me if you have the appliance and what type of fuel it uses.)

$$
\text { .......... Stove/range }
$$

[ ] Gas
[ ] Electric
[ ] Other (SPECIFY):
Don't Have

Q.96 (READ IF NECESSARY: Please tell me if you have the appliance and what type of fuel it uses.)

$$
\text { ........ Clothes dryer }
$$

\footnotetext{
[ ] Gas
$[$ Electric
$[$ [ Other (SPECIFY):
[ ] Don't Have
} 
Q.97 (READ IF NECESSARY: Please tell me if you have the appliance and what type of fuel it uses.)

..........Water heater

[]$_{\text {Gas }}$
[] Electric
$[$ Other (SPECIFY):
[ ] Don't Have

Q.98 How old is your water heater? (IF MORE THAN ONE, MOST RECENTLY PURCHASED) (ENTER 77 FOR DON'T KNOW/UNSURE)

YEARS

Q.99-104 I am going to read the same list of appliances. Assuming you were in the market for new appliances, please tell me what type of fuel you would like for each of the following and the reason for your preference.

Q.99 (READ IF NECESSARY: Assuming you were in the market for new appliances, please tell me what type of fuel you would like for....) .........Stove/range (cooking)

[ ] Gas
[ ETectric
[ ] Other (SPECIFY):
No Preference

(IF NO PREFERENCE, GO TO Q.101)

Q.100 What is the reason for your preference?

Q.101 (READ IF NECESSARY: Assuming you were in the market for new appliances, please tell me what type of fuel you would like for...) ......... Clothes dryer

[ ] Gas
[] Electric
$[$ Other (SPECIFY):
[ ] No Preference

(IF NO PREFERENCE, GO TO Q.103)

Q.102 What is the reason for your preference? 
Q.103 (READ IF NECESSARY: Assuming you were in the market for new appliances, please tell me what type of fuel you for....)

$$
\text { .......Water heater }
$$

[] Gas
[ $]$ Electric
[ $]$ Other (SPECIFY):
[ ] No Preference

(IF NO PREFERENCE, GO TO Q.105)

Q.104 What is the reason for your preference?

Q.105 Do you own or rent your water heater?

$\left[\begin{array}{ll}\text { [ } & \text { Own } \\ \text { [ } & \text { Rent }\end{array}\right.$

Q.106 You mentioned that you own a owned a water heater other than a water heater. Have you ever water heater?

[ ] $\mathrm{Yes}_{\mathrm{No}}$

(IF NO, GO TO Q.109)

Q.107 What type?

[ ] Gas
$[$ Electric
$[$ [ Other (SPECIFY):
[ ] No Preference

Q.108 For what reasons did you switch from to $?$

Q.109 You mentioned that you own a ever owned a stove or range other than a

stove or range. Have you

$\left[\right.$ [ ${ }_{\text {No }}$

(IF NO, GO TO Q.112)

Q.110 What type?

[ ] Gas
[] Electric
[ ] Other (SPECIFY):
[ ] No Preference 

to ?

Q.112 You've indicated your current stove is electric and that you'd be inclined to purchase a gas stove. Assuming you did so, how likely would you be to purchase other gas appliances? Please use a scale of $1-4$, where 4 means very likely and 1 means not at all likely to purchase other gas appliances.

\footnotetext{
[] Not at all likely

[ ] Not very likely

[ ] Somewhat likely

[ ] Very likely

[ ] DON'T KNOW/NOT SURE
}

Q.113 Assuming you were to purchase a gas stove, how likely would you be to switch from an electric heating system to a gas heating system? Again, please use a scale of 1-4.

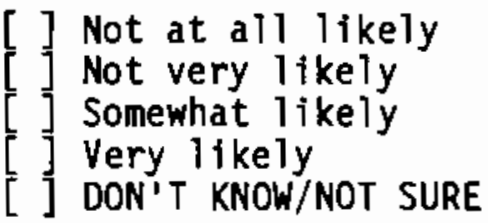

Q.114 You've indicated your current stove is gas and that you would be inclined to purchase an electric stove. Assuming you did so, how likely would you be to purchase other electric appliances? Please use a scale of 1 to 4 , where 4 means very likely and 1 means not at all likely to purchase other electric appliances.

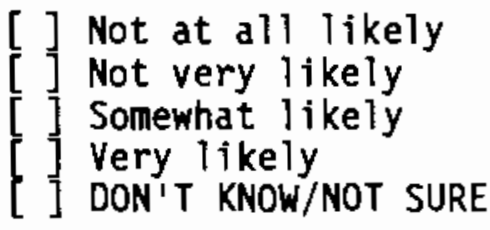

Q.115 Assuming you were to purchase an electric stove, how likely would you be to switch from a gas heating system to an electric heating system? Please use a scale of 1 to 4 .

\footnotetext{
[ ] Not at all likely

Not very likely

Somewhat likely

Very likely

DON'T KNOW/NOT SURE
} 
Q.116 Are you presently in the market for a new water heater, or not?

$\left[\begin{array}{l}\text { Yes } \\ \text { No }\end{array}\right.$

Q.117 What marketing programs, if any, are you aware of that promote a specific type of water heater? (PROBE/CLARIFY)

Q.118 Which of the following types of incentives or programs would MOST influence your choice of fuel (electricity, gas, solar) for water heating? (READ)

[ ] Cash rebates
[ ] Price discounts
[ ] Low interest loans
[ ] Being able to rent or lease
[ ] (DON'T READ) Other (SPECIFY):
[ ] (DON'T READ) Unsure

Q.119 You indicated you recently purchased a water heater. What incentives or discounts, if any, were you offered to purchase brands or types of water heater? (PROBE/CLARIFY) (Manufacturer or utility sponsored?)

Q.120-132 I am going to read a list of statements about how some people feel about various issues. With response choices of Strongly Disagree, Disagree, Neutral, Agree, and Strongly Agree, please tell me how you feel about each of the following statements. (READ)

Q.120 I usually go to several stores to find the lowest prices for the important items I buy.

$\begin{array}{ll}\text { [ ] Strongly Disagree } & 1 \\ \text { [ ] Disagree } & 2 \\ \text { [ ] Neutral } & 3 \\ \text { [ ] Agree } & 4 \\ \text { [ ] Strongly Agree } & 5 \\ \text { [ ] NO OPINION } & 6\end{array}$

Q.121 I consult Consumer Reports or similar publications before making major purchases.

$\begin{array}{ll}\text { [ ] Strongly Disagree } & 1 \\ \text { [ ] Disagree } & 2 \\ \text { [ ] Neutral } & 3 \\ \text { [ ] Agree } & 4 \\ \text { [ ] Strongly Agree } & 5 \\ \text { [ ] NO OPINION } & 6\end{array}$ 
Q.122 I like to try out new products before other people do.

$\begin{array}{ll}\text { [ ] Strongly Disagree } & 1 \\ \text { [] Disagree } & 2 \\ \text { [ ] Neutral } & 3 \\ \text { [ ] Agree } & 4 \\ \text { [ ] Strongly Agree } & 5 \\ \text { [ ] NO OPINION } & 6\end{array}$

Q.123 Electricity prices are fair when you think about the cost of other things today.

$\begin{array}{ll}\text { [ ] Strongly Disagree } & 1 \\ \text { [ ] Disagree } & 2 \\ \text { [ ] Neutral } & 3 \\ \text { [ ] Agree } & 4 \\ \text { [ Strongly Agree } & 5 \\ \text { [ ] NO OPINION } & 6\end{array}$

Q.124 Natural gas is the energy of the future.

$\begin{array}{ll}\text { [ ] Strongly Disagree } & 1 \\ \text { [ ] Disagree } & 2 \\ \text { [ ] Neutra] } & 3 \\ \text { [ ] Agree } & 4 \\ \text { [ ] Strongly Agree } & 5 \\ \text { [ ] NO OPINION } & 6\end{array}$

Q.125 My electric utility works hard to satisfy customers.

$\begin{array}{ll}\text { [ ] Strongly Disagree } & 1 \\ \text { [ ] Disagree } & 2 \\ \text { [ ] Neutra] } & 3 \\ \text { [] Agree } & 4 \\ \text { [ ] Strongly Agree } & 5 \\ \text { [ ] NO OPINION } & 6\end{array}$

Q.126 The safety of natural gas is a concern to me.

$\begin{array}{ll}\text { [ ] Strongly Disagree } & 1 \\ \text { [ ] Disagree } & 2 \\ \text { [ ] Neutral } & 3 \\ \text { [ ] Agree } & 4 \\ \text { [ ] Strongly Agree } & 5 \\ \text { [ ] NO OPINION } & 6\end{array}$


Q.127 I would like to be able to purchase energy equipment and appliances through my electric utility.

$\begin{array}{ll}\text { [ ] Strongly Disagree } & 1 \\ \text { [ ] Disagree } & 2 \\ \text { [ ] Neutral } & 3 \\ \text { [ ] Agree } & 4 \\ \text { [] Strongly Agree } & 5 \\ \text { [ ] NO OPINION } & 6\end{array}$

Q.128 The cost of something I am buying is more important to me than its other qualities.

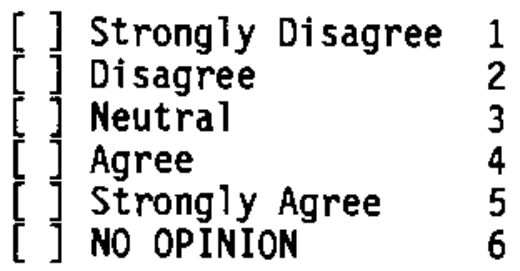

Q.129 Utilities should just concern themselves with providing electricity and nothing else.

$\begin{array}{ll}\text { [ ] Strongly Disagree } & 1 \\ \text { [ ] Disagree } & 2 \\ \text { [ ] Neutral } & 3 \\ \text { [ ] Agree } & 4 \\ \text { [ ] Strongly Agree } & 5 \\ \text { [ ] NO OPINION } & 6\end{array}$

Q.130 My utility should offer low interest loans or rebates for energy conservation investments.

$\begin{array}{ll}\text { [ ] Strongly Disagree } & 1 \\ \text { [ ] Disagree } & 2 \\ \text { [ ] Neutral } & 3 \\ \text { [ ] Agree } & 4 \\ \text { [ ] Strongly Agree } & 5 \\ \text { [ ] NO OPINION } & 6\end{array}$

Q.131 The heat pump system is the most efficient heating and cooling system of the future.

$\begin{array}{lll}\text { [ ] Strongly Disagree } & 1 \\ \text { [ ] Disagree } & 2 \\ \text { [ ] Neutral } & 3 \\ \text { [ ] Agree } & 4 \\ \text { [ ] Strongly Agree } & 5 \\ \text { [ ] NO OPINION } & 6\end{array}$


Q.132 Other people often ask my opinion on new products

$\begin{array}{ll}\text { [ ] Strongly Disagree } & 1 \\ \text { [ ] Disagree } & 2 \\ \text { [ ] Neutral } & 3 \\ \text { [ ] Agree } & 4 \\ \text { [ ] Strongly Agree } & 5 \\ \text { [ ] NO OPINION } & 6\end{array}$

Q.133 Have you ever purchased a video cassette recorder, or VCR?

[ ] Y Yes No (IF NO, GO TO Q.135)

Q.134 About how many years ago did you do so? (ENTER 77 FOR DON'T KNOW) YEARS

(GO TO Q.136)

Q.135 Would you say you are likely to purchase a VCR... (READ)

[ ] Within one year,
[ ] Within one to two years, or
[ ] Not likely to purchase a VCR at all?
[ ] (DON'T READ) Don't Know/Unsure

Q.136 Have you ever purchased a compact disc player?

[ ] Y Nos $\quad$ (IF NO, GO TO Q.138)

Q.137 About how many years did you do so? (ENTER 77 FOR DON'T KNOW)

YEARS

$$
\text { (GO TO Q.139) (IF RENT, GO TO Q.146) }
$$

Q.138 Would you say you are likely to purchase a compact disk player (READ)

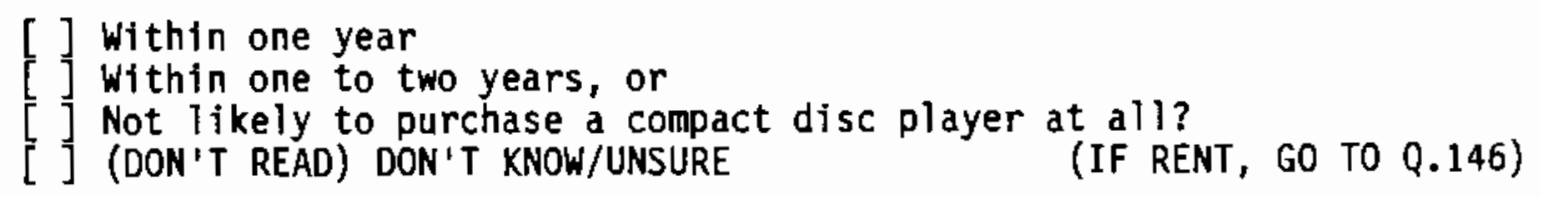

Q.139 In about what year was your residence built? (ENTER 777 FOR DON'T KNOW) (ENTER LAST TWO DIGITS OF THE YEAR)

(IF BEFORE 1910, ENTER 555)

YEAR 
Q.140 (In about what year was your residence built?)

PROBE WITH CATEGORIES

(ENTER TWO DIGIT CODE BELOW)

(01) Before 1910,

(02) Between 1910 and 1929,

(03) Between 1930 and 1939,

(04) Between 1940 and 1949,

(05) 1950 and 1959,

(06) 1960 and 1969,

(07) 1970 and 1973 ,

(08) 1974 and 1978,

(09) 1978 and 1982,

(10) 1982 and 1984, or

(11) After 1984?

(99) (DON'T READ) STILL UNSURE

TWO DIGIT CODE:

Q.141 You mentioned that you have lived in your residence about years. Does that correspond to when you purchased your home?

[ ] Yes (EXPLAIN ON NEXT SCREEN)

EXPLANATION

Q.142 I now have a few final questions. What was the approximate purchase price of your home? (ENTER 77 FOR DON'T KNOW AND 99 FOR REFUSED)

PURCHASE PRICE

Q.143 About how many square feet was your residence when you purchased it (FINISHED AREAS)?

[ ] 600 sq. ft. or less
[ ] $601-1,000$ sq. ft.
[ ] $1,001-1,500$ sq. ft.
[ ] $1,501-2,300$ sq. ft.
[ $2,301-3,100$ sq. ft.
[ ] 3,101 sq. ft. Or more
[ ] UNSURE/DON'T KNOW 
Q.144 How many bathrooms are in your residence?

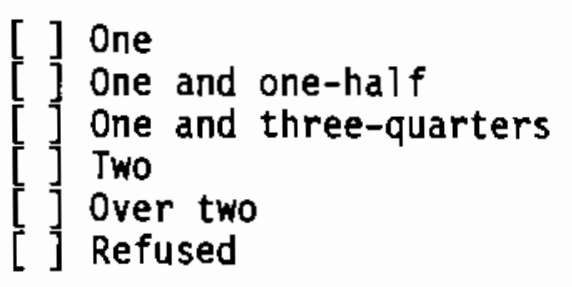

Q.145 In what type of home do you currently live? (READ LIST)

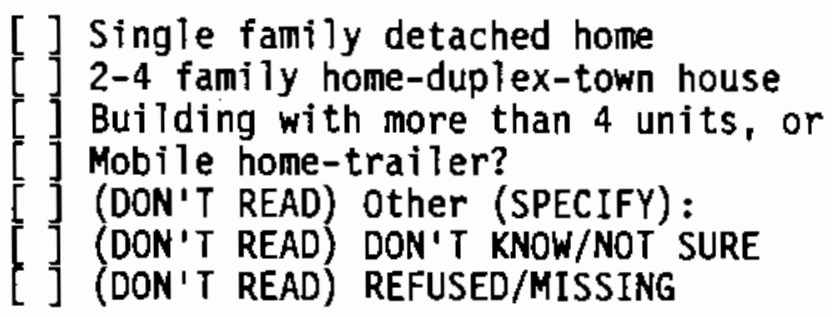

Q.146 Including yourself, how many aduTt people live in your home? (21 years of age or older)

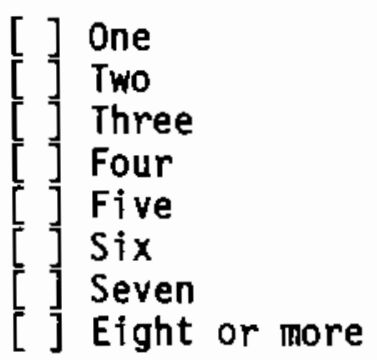

Q.147 RECORD RESPONDENT'S SEX
$\left[\begin{array}{l}\text { Male } \\ \text { [ }\end{array}\right.$ 
Q.148 May I have the age and sex of all people (both adults and children) who live in your home? (START WITH THE OLDEST ADULT MALE, NEXT OLDEST ADULT MALE, ETC. THEN OLDEST < 18 MALE, NEXT OLDEST < 18 MALE, ETC. THEN DO FEMALES IN THE SAME PATTERN.) IF ONLY ONE MALE, ENTER 99 FOR ALL OTHERS TO CONTINUE AGE (MALE \#1)

AGE (MALE \#2)

AGE (MALE \#3)

AGE (MALE \#4)

AGE (MALE \#5)

Q.149 (START WITH THE OLDEST ADULT FEMALE, NEXT OLDEST FEMALE, ETC. THEN OLDEST (18 FEMALE, NEXT OLDEST < 18 FEMALE, ETC.)

IF ONLY ONE FEMALE, ENTER 99 FOR ALL OTHERS TO CONTINUE

AGE (FEMALE \#1)

AGE (FEMALE \#2)

AGE (FEMALE \#3)

AGE (FEMALE \#4)

AGE (FEMALE \#5) 
Q.150 What is your occupation?

(01) Professional

(ENTER TWO DIGIT CODE BELOW)

(02) Management

(03) Clerical

(04) Sales

(05) Craft

(06) Operative

(07) Farm

(08) Service

(09) Homemaker

(10) Retired

(11) Unemployed

(12) Military

(13) Self Employed

(14) Student

(15) Other (SPECIFY ON NEXT SCREEN)

(99) Refused

TWO DIGIT CODE :

OTHER OCCUPATION (SPECIFY):

Q.151 What are the occupations of the other adults in the household? (OTHER \#1) (ENTER TWO DIGIT CODE BELOW)

(01) Professional

(02) Management

(03) Clerical

(04) Sales

(05) Craft

(06) Operative

(07) Farm

(08) Service

(09) Homemaker

(10) Retired

(11) Unemployed

(12) Military

(13) Self Employed

(14) Student

(15) Other (SPECIFY ON NEXT SCREEN)

(99) Refused

TWO DIGIT CODE:

OTHER OCCUPATION (SPECIFY): 
Q.152 What are the occupations of the other adults in the household? (OTHER \#2) (ENTER TWO DIGIT CODE BELOW)

(01) Professional

(02) Management

(03) Clerical

(04) Sales

(05) Craft

(06) Operative

(07) Farm

(08) Service

(09) Homemaker

(10) Retired

(11) Unemployed

(12) Military

(13) Self Employed

(14) Student

(15) Other (SPECIFY ON NEXT SCREEN)

(99) Refused

TWO DIGIT CODE:

OTHER OCCUPATION (SPECIFY) :

Q.153 What are the occupations of the other adults in the household? (OTHER \#4) (ENTER TWO DIGIT CODE BELOW)

(01) Professional

(02) Management

(03) Clerical

(04) Sales

(05) Craft

(06) Operative

(07) Farm

(08) Service

(09) Homemaker

(10) Retired

(11) Unemployed

(12) Mflitary

(13) Self Employed

(14) Student

(15) Other (SPECIFY ON NEXT SCREEN)

(99) Refused

TWO DIGIT CODE:

OTHER OCCUPATION (SPECIFY) 
Q.154 How many years of formal education did you complete?

(ENTER TWO DIGIT CODE BELOW)

(00) Never Attended School (0)

(01) Some Elementary School (1-5)

(02) Completed Elementary School (6)

(03) Some High School (7-11)

(04) Completed High School (12)

(05) Some Trade, Vocational School

(06) Some College (13-15)

(07) Completed College (16)

(08) Some graduate

(09) Completed graduate

(77) DON'T KNOW/NOT SURE

TWO DIGIT CODE:

Q.155 How many years of formal education did the other adults in the household complete? (OTHER \#1)

(ENTER TWO DIGIT CODE BELOW)

(00) Never Attended School (0)

(01) Some Elementary School (1-5)

(02) Completed Elementary School (6)

(03) Some High School (7-11)

(04) Completed High School (12)

(05) Some Trade, Vocational School

(06) Some College (13-15)

(07) Completed College (16)

(08) Some Graduate

(09) Completed Graduate

(77) Don't Know/Not Sure

(99) Refused/Missing

TWO DIGIT CODE: 
Q.156 How many years of formal education did the other adults in the household complete? (OTHER \#2)

(ENTER TWO DIGIT CODE BELOW)

(00) Never Attended School (0)

(01) Some Elementary School (1-5)

(02) Completed Elementary School (6)

(03) Some High School (7-11)

(04) Completed High School (12)

(05) Some Trade, Vocational School

(06) Some College (13-15)

(07) Completed College (16)

(08) Some Graduate

(09) Completed Graduate

(77) Don't Know/Not Sure

(99) Refused/Missing

TWO DIGIT CODE:

Q.157 How many years of formal education did the other adults in the household complete? (OTHER \#3)

(ENTER TWO DIGIT CODE BELOW)

(00) Never Attended School (0)

(01) Some Elementary School (1-5)

(02) Completed Elementary School (6)

(03) Some High School (7-11)

(04) Completed High School (12)

(05) Some Trade, Vocational School

(06) Some College (13-15)

(07) Completed College (16)

(08) Some Graduate

(09) Completed Graduate

(77) Don't Know/Not Sure

(99) Refused/Missing

TWO DIGIT CODE

Q.158 Is your total combined household income... (READ)

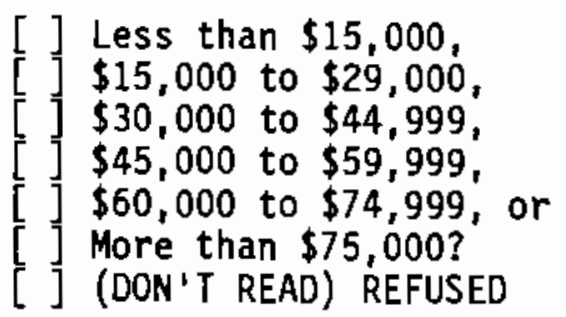


Q.159 Finally, for bookkeeping reasons, what is your zip code?

\section{ZIP CODE}

So I may tell my supervisor I spoke with you, may I please have your first name only?

\section{Name}

And just to verify, did I dial.... (READ NUMBER). Thank you for your time and information. Have a nice day/evening.

AREA CODE

PHONE NUMBER 


\section{DISTRIBUTION}

No. of

Copies

L. Saito

Bonneville Power Administration

- RMRB

1002 N.E. Holloday Street

P.0. Box 3621

Portland, OR 97232

T. 01 iver

Bonneville Power Administration

- RMCC

1002 N.E. Holloday Street

P.0. Box 3621

Portland, OR 97232

K. Keating

Bonneville Power Administration

- RPEB

1002 N.E. Holloday Street

P.0. Box 3621

PortTand, OR 97232

\section{R. Gilman}

Bonneville Power Administration - RPA

1002 N.E. Holloday Street

P.0. Box 3621

Portland, OR 97232

- C. Whitney

8onneville Power Administration

- RMRB

1002 N.E. Holloday Street

P.0. Box 3621

Portland, OR 97232

P. Durocher

Bonneville Power Administration $\rightarrow$ RMRB

1002 N.E. Holloday Street

P.0. Box 3621

Portland, OR 97232
No. of

Copies

- G. Ferguson

Bonneville Power Administration -RMRC

P.0. Box 3621

Portland, OR 97232

- J. Deherrera

Bonneville Power Administration - RMRC

1002 N.E. Holloday Street

P.0. Box 3621

Portland, OR 97232

F. Peterson

Bonneville Power Administration

- RPEE

1002 N.E. Holloday Street

P.0. Box 3621

Portland, OR 97232

F. Abel

Office of Building and Community Services

U.S. Department of Energy

Washington, DC 20585

10 Office of Scjentific and

Technical Information

\section{ONSITE}

DOE Richland Operations Office

J. J. Sutey

I6 Pacific Northwest Laboratory

S. A. Harkreader (5)

R. W. Schultz

M. P. Hattrup (3)

R. 0. Weijo

Publishing Coordination

Technical Report Files(5) 
